\title{
LA CIUDAD DE DIOS DE AGUSTÍN DE HIPONA: SELECCIÓN DE TEXTOS POLÍTICOS
}

\author{
Tomás A. Chuaqui
}

INTRODUCCIÓN

A pesar de que aquí sólo se presenta una selección de una de sus obras - la monumental Ciudad de Dios - y en especial de aquellas secciones de esta obra dedicadas a lo político, es de notar que sus contribuciones intelectuales cubren las más diversas áreas del conocimiento, algunas de las cuales, de hecho, están representadas, en forma no muy sistemática, en esta selección. Además, a todo lector contemporáneo medianamente sensible se le hace evidente el grado en el cual muchas de las ideas de Agustín prefiguran aspectos centrales de la conciencia moderna, traspasando su ubicación cronológica en la antigüedad tardía. Su perspicacia psicológica; sus reflexiones epistemológicas y ontológicas; sus interpretaciones de los textos bíblicos y el desarrollo de los fundamentos de la teología de inspiración cristiana; su explicación de la voluntad humana y de la libertad; dejan una huella profunda en lo que podría llamarse la concepción de mundo de la cultura occidental ${ }^{1}$. En efecto, la filosofía, la teología y la religión para

Tomás A. Chuaqui. Profesor Adjunto de Teoría Política y Director del Instituto de Ciencia Política de la Pontificia Universidad Católica de Chile. PhD, Politics, Princeton University.

${ }^{1}$ Una muy buena selección de artículos dedicados a diversas temáticas del pensamiento de Agustín se encuentra en Stump y Kretzmann, eds. (2001). Uno de los mejores tratamientos de la obra de Agustín como un todo se encuentra en Rist (1997). Más sintético, pero excelente como introducción, es Chadwick (1996).

Estudios Públicos, 99 (invierno 2005). 
Agustín no pueden entenderse de manera discreta, sino que están íntimamente imbricadas unas con otras, y, por lo tanto, sus escritos combinan argumentos y consideraciones de todas ellas. La Ciudad de Dios no es ninguna excepción, y su enorme tamaño se deriva al menos en parte de su intento por incorporar baterías de argumentos tanto filosóficos como teológicos y religiosos para proveer una orientación en cuanto a la manifestación en la historia humana, especialmente la política, de la trama de la providencia.

El pensamiento político de Agustín está disperso en el enorme número de páginas que escribió; de hecho lo mismo se puede decir de gran parte de los temas filosóficos y teológicos en los que se interesó. Además, gran parte de su obra está compuesta en la forma de polémicas con ocasión de las múltiples controversias doctrinales y filosóficas de las que participó de modo protagónico. Estas circunstancias hacen virtualmente imposible resumir sus argumentos para volcarlos en algo así como un "manual” de su pensamiento ${ }^{2}$. En muchas ocasiones, los temas políticos son tratados en su obra de una manera no necesariamente concordante, y a veces están subordinados a requerimientos coyunturales, o polémicos, de la política de su época. Ciertamente no sería justo reducir la obra de Agustín a su contexto histórico, pero sus circunstancias temporales deben ser tomadas en cuenta no tan sólo para comprender su sentido, sino también para reconocer la forma en la que su pensamiento evolucionó en algunos aspectos durante su vida.

Por estas razones, es difícil confeccionar un "compendio" del pensamiento político de Agustín que sea medianamente coherente y que además dé cuenta de las diversas etapas por las que pasó 3 . En vistas, por lo tanto, a estas consideraciones — como también a limitaciones de espacio—, en esta selección sólo se incluyen escritos provenientes de su obra más reconocida e influyente en cuanto a su reflexión sobre lo político: La Ciudad de Dios. Debe ser consignado, eso sí, que incluso esta obra fue compuesta durante largos y muy acaecidos catorce años de la vida de su autor (entre el 413 y el 427). Escribir este libro fue "una larga y pesada tarea"4, ya que en ella Agustín se propuso "convencer a los soberbios del gran poder de la humildad"5, mostrando, ni más ni menos, el alcance de la manifestación de la voluntad divina en el correr de los tiempos y en la serie de acontecimientos humanos.

${ }^{2}$ Rist (1997), pp. 10-11, establece este mismo punto.

${ }^{3}$ Dos intentos relativamente exitosos de seleccionar los escritos políticos de Agustín son las ediciones de Paolucci (1962), y de Atkins y Dodaro (2001). Esta última, eso sí, se concentra casi exclusivamente en las cartas de Agustín. El esfuerzo más logrado, en mi opinión, es el de Dyson (2001).

${ }^{4}$ La Ciudad de Dios, Libro I, Prólogo.

${ }^{5}$ Ibid. 
La vida de Agustín de Hipona ${ }^{6}$ (354-430) transcurre durante los comienzos de un período histórico comúnmente llamado "antigüedad tardía" que se extiende, aproximadamente, entre los siglos III y VII. Este período en la historia de Europa —especialmente de Europa mediterránea— se caracteriza por la recepción y transformación de las ideas de la antigüedad clásica en el contexto de la creciente, aunque dificultosa, difusión y consolidación del cristianismo en Europa occidental. De esta manera, conviven durante los años de vida de Agustín las culturas pagana y cristiana, generando una rica mixtura a través de un proceso que no estuvo exento de conflictos y resistencias en la medida en que las fronteras culturales y religiosas iban cambiando de lugar, o, más bien, haciéndose más difusas en algunos lugares y más nítidas en otros ${ }^{7}$.

En un sentido casi literal, Agustín encarna esta mixtura. Nace en el pequeño pueblo de Tagaste, ubicado en el norte de África, en lo que hoy es Algeria. Este territorio formaba parte del Imperio romano ya desde el siglo I. De padre pagano y madre cristiana — esta última posteriormente conocida como Santa Mónica-, se vio expuesto desde temprana edad a ambas culturas, la pagana y la cristiana, que coexistían en la vida cotidiana del Imperio. A pesar de los persistentes esfuerzos de su madre por exponer al joven Agustín a las creencias cristianas, no fue criado como cristiano y, en cambio, se acercó en su juventud a lo más selecto de la alta cultura romana.

Como es bien sabido, Agustín mismo nos lega una versión de algunos aspectos de su vida en sus afamadas Confesiones, obra compuesta en el año 401. A pesar del incuestionable valor tanto literario como filosófico y espiritual de esta obra, quien busque en ella un recuento de los eventos de la vida de Agustín terminará decepcionado: las Confesiones no son una "autobiografía” en el sentido que normalmente se le atribuye a tal género, ya que más que contar la historia de los acontecimientos de su vida, Agustín reconstruye su trayectoria intelectual, espiritual y religiosa, dando a conocer, en especial, el proceso que lo llevó a la conversión al cristianismo (en el año 387) y a la consagración de su vida a la fe y a la Iglesia católica. Las Confesiones, por lo tanto, nos permiten conocer, al menos desde la perspectiva de Agustín, aspectos de la cultura intelectual del Imperio romano durante la segunda mitad del siglo IV. Por ejemplo, en el proceso de su

${ }^{6}$ La mejor biografía de Agustín sigue siendo la de Brown, originalmente publicada en 1967. La última edición del año 2000 contiene un muy interesante epílogo en el que se revisa el impacto en la bibliografía especializada del descubrimiento, en décadas recientes, de cartas y sermones de Agustín que no se conocían. También son valiosas las biografías de Wills (2001) y de Courcelles (1998). Para la evolución del pensamiento de Agustín hasta su conversión, véase especialmente, O’Meara (2001).

7 Para este tema, véase Brown (1989); (1992); y (1997). Para la cristianización del norte de África en los tiempos de Agustín, véase Merdinger (1997). 
desarrollo intelectual, y en su búsqueda permanente por la paz espiritual derivada de la certeza, Agustín estudió y se hizo un buen conocedor de las ideas filosóficas y religiosas de diversos grupos, tales como el maniqueísmo y el escepticismo ${ }^{8}$.

Agustín recibe, y se da a sí mismo, la educación más sofisticada disponible en la época, con el objeto de satisfacer su ambición original de convertirse en un maestro de retórica y en un intelectual de renombre; de hecho, estaba bien encaminado en esta dirección al momento de su conversión. Es instruido en los clásicos de la literatura latina, como Virgilio y Horacio, y así también en los grandes historiadores romanos como Salustio y Tito Livio. Además, a pesar de no haber aprendido bien el griego, conoce las ideas principales de la filosofía griega a través de autores latinos como Cicerón y Plotino. En efecto, como cuenta en las Confesiones, fue la lectura de un diálogo perdido de Cicerón llamado "Hortensio" la que indujo a Agustín a trasladar sus intereses desde el mero uso pirotécnico y retórico del lenguaje en búsqueda de la persuasión, a la búsqueda de la sabiduría que implica la actividad filosófica ${ }^{9}$. Agustín se convencerá eventualmente de que se accede a la sabiduría verdadera sólo a través de la fe. De esta manera, su primer ímpetu filosófico se inscribe en su proceso de conversión.

Por su parte, el neoplatonismo de Plotino y de otros fue particularmente importante en la formación intelectual y espiritual de Agustín ya que le permitió reconocer, probablemente a través de la influencia de San Ambrosio, que el cristianismo era "filosóficamente respetable". Al descubrir que, por ejemplo, el Evangelio según San Juan y las Epístolas de San Pablo contienen una fuerte impronta platónica, la que el mismo Agustín se encargó posteriormente de hacer manifiesta, logró deshacerse de la idea, propia de los maniqueos, de que Dios sería una entidad corpórea, la que provocaba fuertes contradicciones filosóficas, y dificultaba su aceptación de la fe cristiana ${ }^{10}$.

${ }^{8}$ Con diversos grados de convencimiento, aunque nunca completo, Agustín pasó largos años interesado en las doctrinas de Manes (216-277). A pesar de aceptar a Jesús como un hombre sabio, el maniqueísmo rechazaba gran parte de los textos bíblicos, tanto del Nuevo como del Antiguo Testamento. Un aspecto que le pareció particularmente atractivo a Agustín era la doctrina maniquea de que la existencia del mal se explicaba por el permanente conflicto entre las fuerzas de la luz versus las fuerzas de la oscuridad. De ahí el dualismo que normalmente asociamos con el término "maniqueo". La escuela escéptica, o Academia, fue la heredera de la Academia platónica. Ante las perplejidades que se le presentan a la mente humana, los escépticos recomendaban la "suspensión de juicio", así evitando la incomodidad de saberse incapaz de arribar a la certeza. Luego de su desilusión con los maniqueos, Agustín consideró brevemente adoptar una posición escéptica de este tipo.

${ }^{9}$ Agustín, Confesiones (1947), 3, IV; pp. 161-163.

10 Para este punto, véase O’Meara (2001), pp. 112-114. También Brown (1967), pp. 88-100. 
A la vez, Agustín llegó a convencerse de que el neoplatonismo sólo intuía la verdad, ya que sus adeptos aproximaban, pero no podían alcanzar la verdad revelada, la cual requiere para su conocimiento de la intervención de la gracia divina y la asistencia de la autoridad de las Sagradas Escrituras. La razón por sí sola, puesta en ejecución en forma admirable por los filósofos neoplatónicos, es insuficiente para hallar la verdad. Desde esta perspectiva, la verdad, sólo intuida por los neoplatónicos, se hace disponible a todos, a través de la gracia y de las Sagradas Escrituras, las que son "accesibles a la lectura de cualquiera [...] dándose por una parte a todos con suma llaneza de palabras y con gran humildad de estilo, y por otra parte ejercitando el entendimiento de aquellos que no son ligeros de corazón, y acogiendo y dando cabida a todos en la anchura de su regazo". ${ }^{11}$ Por lo tanto, el cristianismo incorpora, transforma y supera las intuiciones de los neoplatónicos, haciendo además de la verdad un objeto de conocimiento inteligible para todos, y no reservado para los doctos. La labor apostólica de Agustín vertida en sus escritos, sus cartas y sus sermones, convierte el platonismo subyacente en las Sagradas Escrituras en la experiencia vívida de la fe del creyente común. Quizás Agustín habría estado de acuerdo con la mordaz sentencia de Nietzsche en cuanto a que "el cristianismo es platonismo para el pueblo”12 — restándole, claro está, la evidente sorna que Nietzsche quisiera inyectarle al comentario.

Luego de concluir que ni el maniqueísmo, ni el neoplatonismo, ni el escepticismo daban respuestas satisfactorias a sus demandas espirituales e intelectuales, y habiendo pasado por un período de difícil turbulencia interna, Agustín se convierte al cristianismo en el año 387. Es la lectura de un pasaje, escogido al azar, de la Epístola a los Romanos de San Pablo (13, 1314) la que finalmente lo induce a derribar las barreras que había interpuesto para entregarse enteramente a la $\mathrm{fe}^{13}$. De hecho, la interpretación de San Pablo del mensaje de Jesús marcará su obra durante el resto de su vida. Es bautizado por San Ambrosio, y es ordenado sacerdote en el año 391. Cinco años más tarde, fue nombrado obispo de Hipona, actualmente Annaba en Algeria. Permaneció como tal durante los siguientes 35 años hasta su muerte en 430 , involucrado permanentemente en controversias relativas a la definición de la fe cristiana, y su contribución a la resolución de estas disputas, generalmente en clave paulina, deja una notoria impronta en el desarrollo posterior de la cultura occidental. Espero que la lectura de las selecciones que siguen confirme tal aseveración.

${ }^{11}$ Confesiones (1947), p. 271.

12 Nietzsche (1994), p. 19.

${ }^{13}$ Este crucial episodio de la vida de Agustín es relatado en Confesiones (1947), VIII, 12, pp. 378-381. 
El impulso inicial para la composición de La Ciudad de Dios fue la reacción, tanto de cristianos como de paganos, a la invasión y saqueo de la ciudad de Roma que los visigodos liderados por Alarico perpetraron en 410. Muchos consideraron que la invasión de Roma no podía sino significar la ira de los dioses tradicionales de Roma en respuesta a la adopción oficial de la religión cristiana en el Imperio. Incluso algunos cristianos católicos llegaron a poner en duda sus creencias religiosas en vista de la ocurrencia de lo impensable: la misma ciudad de Roma, centro y corazón del Imperio, violentada por invasores bárbaros, liderados por un cristiano arriano ${ }^{14}$.

Para entender esta reacción es necesario ubicarse en el contexto de la interpretación, bastante generalizada, que originalmente se le dio a la conversión al cristianismo del emperador Constantino, y la eventual declaración del cristianismo como religión oficial del Imperio en el año 350. El proceso de cristianización del Imperio provocó la reflexión sobre la relación entre las estructuras políticas y religiosas, o si se quiere, usando un lenguaje más moderno, entre el Estado y la Iglesia ${ }^{15}$. Originalmente se interpretó la existencia de las dos esferas como enteramente compatibles: tanto la Iglesia como el Imperio romano eran comúnmente entendidos como reflejos del reino de los cielos en la Tierra. Era natural para muchos romanos que profesaban el cristianismo pensar que Constantino había efectuado el traslado del reino de los cielos a la Tierra, esto es, que un Imperio romano cristiano manifestaba y proyectaba la voluntad divina de instalar e instituir el mensaje de Cristo en el mundo, albergando a la Iglesia en su interior. La noción de que el Imperio sería un vehículo para la religión cristiana, y así encarnaría el plan divino de la salvación humana, se había convertido en un lugar común. La vulnerabilidad de Roma demostrada por la invasión de Alarico puso en duda tal interpretación, y, además, avivó la demanda de los paganos por el retorno a las tradiciones religiosas originales del Imperio.

A pesar de que el mismo Agustín pasó por una etapa en la que en forma bastante optimista identificó la cristianización del Imperio con la venida del reino de Dios a la Tierra ${ }^{16}$, para cuando comienza a escribir La Ciudad de Dios en el año 413, ya había abandonado tal idea. Su intención, especialmente en los primeros diez de los veintidós libros de La Ciudad de Dios, es explícitamente polémica: Agustín pretende rebatir los argumentos de los paganos quienes consideraban que la causa de la vulnerabilidad de Roma se debía a la intromisión del cristianismo en el Imperio. El subtítulo de la obra - Contra Paganos - remarca su intención polémica, y se podría

\footnotetext{
${ }^{14}$ Los arrianos negaban la divinidad de Jesús, y su consustancialidad con el Padre, en efecto rechazando la doctrina de la Santísima Trinidad.

15 Véase Deane (1963), pp. 116-153.

16 Markus (1970), pp. 22-71.
} 
decir incluso que se inscribe en la serie de polémicas que Agustín compuso en respuesta a las más diversas escuelas filosóficas y doctrinas religiosas que competían por conquistar adeptos en la época, algunas de las cuales él mismo consideró, antes de su conversión, como, al menos, plausibles ${ }^{17}$.

Sin embargo, La Ciudad de Dios va mucho más allá en sus preocupaciones que ensayar la refutación de aquellos que atribuían la catástrofe de la invasión visigoda al abandono de los dioses paganos tradicionales. En especial en su segunda parte, desde el capítulo once al veintidós, Agustín desarrolla una interpretación teológica de la historia, lo que hace de $L a$ Ciudad de Dios una combinación de argumentación polémica y de meditación personal sobre la historia humana, y sobre los roles del Imperio romano y de la Iglesia católica en esa misma historia. De hecho, los mismos temas son tocados en sermones y cartas antes de la invasión de Roma, incluyendo la imagen de las dos ciudades, la que será tratada más abajo ${ }^{18}$.

En La Ciudad de Dios Agustín rechazó tanto el optimismo de aquellos que veían en el Imperio romano el establecimiento del reino de los cielos en la Tierra, como la desesperación de otros al desilusionarse de esta concepción. El Imperio, y todo el resto de las estructuras políticas, no pueden considerarse como instrumentos indispensables para el avance del cristianismo, pero tampoco significan un obstáculo para su realización: cualquiera de las dos actitudes involucraría poner en cuestión la misma omnipotencia divina. Desde la perspectiva providencial, el Imperio era fundamentalmente neutro. Toda estructura política no es ni santa ni diabólica en sí misma, sino que, como toda obra humana, su valor último depende de la fe de sus creadores y partícipes. De esta manera, Agustín des-diviniza la historia del Imperio, al tiempo que desmitifica las versiones paganas de la misma. Su interés es declarar que no existe una relación especial entre el destino histórico de Roma, ni de ninguna otra sociedad, y la marcha de la providencia. Todas las sociedades contienen dentro de sí individuos, grupos y asociaciones que, por gracia divina conferida, transitan en la Tierra hacia la salvación eterna; pero también contienen individuos, grupos y asociaciones que están ancladas a lo terrenal, y que por lo tanto no se encontrarán con la divinidad en el fin de los tiempos. Sólo Dios sabe quienes pertenecen a cada grupo — ya que sólo Él "escruta los corazones"19— y, por ende, nadie puede reconocer la membresía de unos u otros.

${ }^{17}$ Entre las que se pueden contar Contra Académicos, en Escritos Filosóficos $2^{\circ}$ (1951); Escritos Antipelagianos (1971); Escritos Antimaniqueos (1986); Escritos Antidonatistas (1988b); Escritos Antiarrianos (1990).

18 Véase O’Daly (1999), pp. 28-32; y, por ejemplo, la carta 111: Agustín (1967), pp. 746-756.

${ }^{19}$ Romanos 8,27. 
Agustín simboliza esta ambigüedad de las cosas humanas con la imagen de las dos ciudades: la ciudad de Dios y la ciudad terrena. A ojos humanos, ambas ciudades son constructos abstractos, en el sentido de no referirse a ninguna asociación especificable. Para la divinidad, en cambio, se remiten a personas nítidamente distinguibles. Agustín define a las dos ciudades en forma equivalente como: la ciudad de los santos y la de los injustos; del orgullo y de la humildad; de los piadosos y los no piadosos; de los elegidos y los condenados. En último término, una se dirige hacia el bien, y alcanzará la salvación eterna; la otra subordina este bien al interés propio temporal, y está condenada al infierno. Todas las sociedades humanas contienen ambas ciudades: sólo en el juicio final se separará a los justos de los injustos. En el Imperio romano (como en todas las agrupaciones humanas, incluyendo a la misma Iglesia católica) las dos ciudades están mezcladas y se relacionan entre sí.

De esta manera, las dos ciudades son el resultado de motivaciones humanas internas fundamentalmente divergentes: la motivación principal de los miembros de la ciudad terrena es el amor propio, con todas las connotaciones de orgullo y soberbia que esta categoría sugiere; en cambio, la motivación principal de los miembros de la ciudad de Dios es el amor a la divinidad, un amor que traspasa las cosas terrenales, sin valorarlas en sí mismas, sino tan sólo en tanto dones divinos. Así, los miembros de la ciudad de Dios se aman a sí mismos sólo en tanto perciben la presencia divina en su ser. Se trata de un amor de sí mismo desprovisto de orgullo y soberbia, y en consideración a la persona como criatura divina, tal como el resto del cosmos. Las dos ciudades se definen y diferencian a partir de los amores últimos (las motivaciones íntimas) de sus miembros, pero en las comunidades humanas, y en el transcurrir del tiempo, se encuentran superpuestas, y los "ciudadanos" de una y de otra necesariamente se relacionan entre sí. A partir, entonces, de motivaciones internas de los seres humanos, Agustín construye una concepción de lo político que se inscribe en una teoría de la historia. En efecto, las dos ciudades son también una representación del combate que se vive hacia el interior de todo ser humano entre el espíritu y la carne.

La razón por la cual las ciudades están mezcladas es porque existen “amores intermedios" que ambas ciudades tienen en común, y cuya consumación es necesaria para acceder a los fines últimos de unos y otros, como, por ejemplo, la satisfacción de necesidades materiales, provisiones de seguridad personal y pública, y el establecimiento de relaciones sociales ordenadas y pacíficas. Estos objetos de los amores intermedios son valorados tanto por los miembros de la ciudad de Dios como por los de la ciudad terrenal, aunque las razones que tienen para buscar su realización son radi- 
calmente diferentes. Es en el ámbito de la manifestación de estos amores intermedios en el que funcionan las instituciones políticas, ya que, no obstante la variedad de formas que toman, es su función proveer mecanismos para la consecución de estos bienes comunes a ambas ciudades.

El fin principal de las instituciones políticas es el establecimiento de la paz en la Tierra: el valor de la paz terrena, para los miembros de la ciudad de Dios, está referido al conseguimiento de la paz eterna, al goce de la paz celestial. Las sociedades seculares, entonces, son para Agustín formas de organización social dentro de las cuales está contenida la ciudad de Dios, aunque ésta trascendería toda organización terrenal en el camino hacia su último objetivo: la paz eterna. La historia de la humanidad es el marco en el cual se representa el conflicto entre las dos ciudades.

Este énfasis de lo político como maneras en las cuales establecer la paz, está profundamente ligado a una concepción pesimista de la condición humana. Agustín plantea una noción minimalista del bien común en relación a lo político, ya que lo que realmente importa no son los bienes de este mundo sino el bien último: la paz eterna. La naturaleza humana, profundamente marcada por el pecado original y las debilidades inherentes a esta condición, impide que, en este mundo, y en la política en particular, sea razonable aspirar a algún bien no asociado a la salvación. Es por esta razón que la consecución de la paz es el fin primordial de lo político puesto que ella permite el "peregrinaje" de la ciudad de Dios hacia la trascendencia. En efecto, los términos precisos de esta paz no son importantes, es decir, las formas políticas no son especialmente relevantes. Lo único realmente significativo es el asegurar la posibilidad de este peregrinaje a través del establecimiento de la paz terrena. La paz dentro de la ciudad terrena permite la coherencia de las voluntades con respecto a las necesidades terrenas, y se remite a la obtención de la paz eterna.

Como se ha dicho anteriormente, este peregrinaje requiere estar tocado por la gracia divina. Toda la teoría política de Agustín está informada por su doctrina de la gracia divina. Para Agustín la intervención divina es absolutamente necesaria, ya que la naturaleza humana está permanente y profundamente marcada por el pecado original. Los miembros de la ciudad de Dios lo son sólo por don de la gracia divina. Ningún ser humano tiene la capacidad de resistir el mal por sí solo, sino que sólo con la ayuda divina somos capaces de controlar nuestras tentaciones pecaminosas. Nuestra voluntad libre es insuficiente por sí sola para aproximar el bien.

Por cierto, esta concepción de la naturaleza humana tiene consecuencias en relación a lo político: todo régimen coercitivo —y la necesidad de un régimen coercitivo- es una consecuencia del pecado. Por ejemplo, la existencia de uno de los regímenes coercitivos más extremos, la esclavitud, 
se explica bajo esta lógica. Aunque la esclavitud es contraria a la igualdad natural de los seres humanos, es una consecuencia de la condición pecaminosa en la que nos encontramos. Por lo tanto es una institución tolerable, aunque no necesariamente justa (en el sentido de que cuente con la aprobación de Dios) en cada caso en particular.

Igualmente, y más en general, los gobiernos y su utilización de la fuerza, son parte del castigo divino por el pecado. La coerción y la aplicación de castigo en los gobiernos son para Agustín elementos necesarios en el mundo terrenal. Los seres humanos son sociales por naturaleza, pero no políticos, es decir, si no hubiéramos caído por el pecado original, el gobierno sería innecesario. El objeto último de lo político es controlar el conflicto y el desorden que resultan de relaciones sociales en el contexto de circunstancias caracterizadas por la presencia del pecado en la Tierra. El rol de las instituciones de gobierno no es el establecimiento de la ciudad de Dios (del orden perfecto) sino minimizar el desorden. Sin embargo, el objetivo último de la protección de la paz es justamente permitir que los miembros de la ciudad de Dios puedan completar su peregrinaje en la Tierra para alcanzar la unión última con la divinidad al final de los tiempos. En este sentido, Agustín llegó a estar dispuesto, luego de alguna incomodidad, a aceptar la ayuda del Estado político en la represión de aquellos que se rebelaran contra la Iglesia católica, en el entendido de que los movimientos que resistían a la autoridad de la Iglesia y que inducían al error a los fieles, obstaculizaban el peregrinaje de la ciudad de Dios. Esto se aplica en especial a aquellos movimientos que estaban dispuestos a hacer uso de la violencia para resistir a la Iglesia, como fue el caso de algunos partidarios del donatismo ${ }^{20}$.

La consecución de la paz, requiere, según Agustín, que lo político se constituya en la manifestación de lo justo. Su concepción de lo político se deriva, en gran parte, de la definición de "república" que ofrece Cicerón: "la cosa pública (república) es lo que pertenece al pueblo; pero pueblo no es todo conjunto de hombres reunido de cualquier manera, sino el conjunto de una multitud asociada por un mismo derecho, que sirve a todos por igual"21. Agustín corrige esta definición reemplazando "derecho" (ius) por "justicia” (iustitia), así argumentando que no basta la existencia de un sis-

${ }^{20}$ La disputa entre los donatistas y la Iglesia se remontaba a la última persecución de cristianos efectuada por el emperador Diocleciano, quien ordenó a todos los sacerdotes entregar sus textos sagrados ("traditores" - literalmente aquellos que "entregaron" los textos). Para el obispo Donato, aun si estos sacerdotes manifestaban arrepentimiento, su membresía en la Iglesia debía estar vedada, y por ende todo sacramento por ellos celebrado era inválido. Este movimiento fue particularmente importante en el norte de África, donde los niveles de fanatismo de sus seguidores pusieron realmente en riesgo la unidad de la Iglesia. El cisma donatista tuvo uno sus períodos más violentos durante el obispado de Agustín.

${ }^{21}$ Cicerón, Sobre la República (1991), pp. 62-63. 
tema de reglas o leyes para que se pueda hablar de un "pueblo" y, por ende, de una "república", sino que debe existir auténtica justicia. Para Agustín, la justicia solamente proviene de Dios. Por lo tanto, a partir de la definición de Cicerón Agustín concluye que no puede existir una república verdadera en la medida en que no exista justicia verdadera, es decir, en la medida en que la voluntad divina, la justicia divina, no sea absolutamente respetada. Interpretada de esta manera, la definición de Cicerón nos da una sola república genuina: sólo aquélla en la cual la verdadera justicia está perfectamente realizada. Todos los demás sistemas políticos no son más que, en mayor o menor medida, bandas de ladrones, tal como deja establecido claramente en el capítulo 4 del Libro IV de La Ciudad de Dios.

Para referirse a los sistemas políticos existentes, ya no el ideal de convivencia consignado con la imagen de la ciudad de Dios, Agustín utiliza la definición de Cicerón en términos neutros, es decir sin carga ética: "el conjunto multitudinario de seres racionales asociados en virtud de una participación concorde en unos intereses comunes”22. Una república, entonces, puede ser constituida por la búsqueda de intereses, o "amores", diversos: mientras más nobles sean estos intereses, mejor será este pueblo, y más genuina será la república en cuestión. En efecto, es así como Agustín establece la diferencia entre la ciudad de Dios y la ciudad terrenal: una, la ciudad de Dios, está unida por su amor a Dios; la otra está unida por su amor a las cosas terrenales. Pero, la genuina justicia sólo puede existir en una sociedad cristiana, unida en su amor a Dios, y, por lo tanto, es sólo ésta la que puede considerarse como una república auténtica.

Quizás nada remarque más claramente esta diferencia entre las dos ciudades que el análisis que Agustín ofrece de las distintas concepciones de "gloria" que corresponden a las dos ciudades. Como dice Peter Brown:

La Ciudad de Dios es un libro sobre la "gloria”. En él, Agustín drena la gloria del pasado de Roma para proyectarla lejos del alcance de los hombres, en "la gloriosísima ciudad de Dios"23. Las virtudes que los romanos les adscribieron a sus héroes serían realizadas sólo por los ciudadanos de esta otra ciudad; y es sólo hacia el interior de los muros de la Jerusalén Celestial, en que la noble definición de Cicerón de la esencia de la república romana podría ser alcanzada ${ }^{24}$.

Es decir, la versión de la justicia propia de la república romana es incompleta puesto que su motivación, incluso en sus mejores instancias, es el deseo de gloria personal. Los grandes héroes de la república romana

\footnotetext{
${ }^{22}$ Agustín, La Ciudad de Dios (1988a), L. XIX, cap. 24.

${ }^{23}$ Estas son las primeras palabras de la obra.

${ }^{24}$ Brown (1967), pp. 311-312.
} 
pusieron en ejecución sus virtudes ciertamente por amor a la patria, pero con vistas a la consecución del aumento de poder o prosperidad de la ciudad terrena, y motivados por el deseo de ser reconocidos y alabados en este mundo. De esta manera, los ejemplos más nobles y enaltecidos de la virtud romana se insertan en una actividad política disminuida en comparación con la aspiración propia de los miembros de la ciudad de Dios, cuyas virtudes no sirven para alimentar su orgullo, sino para glorificar a la divinidad. Las obras de Tito Livio y Salustio son especialmente importantes en este sentido, ya que rememoran las grandes acciones de los héroes de la antigua república romana ${ }^{25}$. Agustín reconoce tales grandes acciones, y en efecto sugiere que prefiguran en tono menor las virtudes cristianas, puesto que favorecen el aprendizaje y la superación de lo mejor de la cultura romana entre los cristianos. Estas características de la cultura romana explican por qué Dios permitió el engrandecimiento de Roma: lo mejor de su cultura siempre estuvo al servicio del peregrinaje de los miembros de la ciudad de Dios.

No es casual, por ejemplo, que Agustín cite parte de los conocidos versos en los que Anquises, el padre de Eneas, exhorta al pueblo romano desde los campos Elisios: “Tú, romano, recuerda tu misión: ir rigiendo los pueblos con tu mando. Éstas serán tus artes: imponer leyes de paz, conceder tu favor a los humildes y abatir combatiendo a los soberbios"26. La similitud con el versículo de Santiago 4, 6 es notable - "Dios resiste a los soberbios y da su gracia a los humildes"27 — y Agustín la aprovecha para remarcar que los miembros de la ciudad terrena, es decir de la Roma pagana de Virgilio, se atribuyen a sí mismos, llenos de orgullo, características que son propias de la divinidad. Es más, es posible argumentar que los textos paganos que Agustín cita, es decir, que están contenidos en La Ciudad de Dios, simbolizan a la ciudad terrena en tanto ésta cumple la función — tal como Virgilio, Platón, Cicerón, etc. - de facilitar el peregrinaje de los miembros de la ciudad divina hacia el conocimiento y el encuentro último con Dios.

Es posible graficar esta utilización del pensamiento romano con múltiples conceptos y categorías que Agustín recoge, transporta y traduce de la alta cultura latina al sistema teológico y filosófico cristiano y de inspiración bíblica que construye. Instruido en las artes de la retórica y de la persuasión, Agustín, con dexteridad lingüística asombrosa, enmienda el

\footnotetext{
25 Maquiavelo intentará recuperar el sentido original de la categoría “gloria”, des-cristianizándola y atribuyéndole una significación estrictamente política basado en los mismos autores romanos que Agustín pretende desplazar. Para este tema, véase Chuaqui (2000), pp. 403-435.

${ }^{26}$ Virgilio, Eneida (2000), p. 191.

27 Santiago 4,6.
} 
sentido de estos conceptos y categorías, sirviéndose del campo ideológico de la cultura política, literaria y filosófica de Roma, para allanar el camino de la absorción e incorporación de la escala de valores cristiana. Este esfuerzo, por cierto, se inscribe en el contexto de su convicción de que la historia humana está providencialmente informada, y que por ende todo suceder necesariamente contribuye a los propósitos divinos. De este modo, los más elevados aspectos de la cultura latina, sus conceptos y categorías que señalan su campo ideológico, aproximan la verdad revelada por Cristo. En otras palabras los mejores productos de la práctica y de la razón pagana son versiones, admirables, pero imperfectas e incompletas, de los propósitos que la divinidad inscribe en la historia y la naturaleza humana. Como se ha dicho, dos conceptos son particularmente significativos y representativos de la inserción providencial de la cultura e ideología romana, en cuanto al ámbito de lo político: las nociones de república y de gloria.

Pero no sólo lo más elevado de la producción intelectual y política de la historia humana sirve los propósitos escatológicos de la divinidad. El mal también sirve al bien. "En tales tinieblas de la vida social”28 el indudable sufrimiento que es propio de la vida humana ocupa un lugar ineludible en la proyección de la voluntad divina a través del tiempo. La vida social, en todos sus niveles desde el hogar a la comunidad política y a los más extensos imperios, está plagada de males y sufrimientos; en efecto, el mal se distribuye por todo el cosmos. Sin embargo, el cosmos, y en particular la vida social que contiene, deben ser amados, en tanto permiten y avanzan el peregrinar de los miembros de la ciudad divina.

Es en este contexto que para Agustín la autoridad política tiene el rol de reprimir a quienes se rebelan en contra de la autoridad espiritual de la Iglesia. Todas las instituciones políticas y judiciales, y sus brazos administrativos y coercitivos tendrían el mismo objetivo: controlar a los injustos y crear un espacio para que los justos puedan vivir en inocencia. Las obligaciones de los miembros de una sociedad son profundas e ineludibles. Requieren dedicación continua, a pesar de que los esfuerzos por lograr la justicia y la paz en las sociedades humanas estén siempre condenados a la frustración y al fracaso. Nunca es posible confiar en la derrota completa del mal. Siempre el mal está al acecho, puesto que los seres humanos somos incapaces de establecer un orden propiamente justo a través de nuestros limitados recursos intelectuales y morales. Lo político es parte de un orden, pero no es un orden cósmico racional, platónico, accesible a la razón. Es más bien un orden misterioso; el orden de los inescrutables designios divinos, que sólo "vemos en un espejo, en enigma"29.

\footnotetext{
${ }^{28}$ La Ciudad de Dios (1988a), XIX, 6.
}

${ }^{29}$ Corintios 13,12. 
Las leyes humanas participan entonces de la ley divina o natural, pero no son equivalentes, ni están relacionadas directamente. Las leyes humanas y lo político están, como todas las cosas humanas, contaminadas por el pecado; pero, como partícipes de la divina providencia, su propósito genuino debería ser controlar los efectos del pecado y ser un remedio para el desorden y el conflicto inherentes a la condición pecaminosa de los seres humanos.

Como lo político es resultado de nuestra condición pecaminosa, a lo que aspira Agustín, en último término, es a la disolución de lo político. El orden perfecto es un orden apolítico, carente de coerción y autoridad humana. En la medida en la que este orden no se alcance, sin embargo, tenemos una obligación ineludible de participar de lo político, en el sentido de intentar asegurar el peregrinaje de la ciudad de Dios hacia la paz eterna ${ }^{30}$.

En fin, es imposible no discernir un cierto tipo de pesimismo en el pensamiento político de Agustín. Para él es evidente que lo político no es un espacio de redención, ni de liberación, sino más bien de control y pacificación. Pero lo político sólo puede cumplir estas funciones adecuadamente y con justicia si es que se lleva adelante en la esperanza de la redención y la liberación del pecado. Guardando las proporciones, y haciendo todas las salvedades que obviamente vienen al caso, quizás se puede caracterizar el pesimismo político de Agustín de manera similar al que se le atribuyó en alguna ocasión a Michel Foucault: es un pesimismo sin desesperanza ${ }^{31}$.

$$
* * *
$$

La selección de textos aquí incluida se ha tomado de la excelente edición bilingüe traducida por Santos Santamarta del Río y Miguel Fuertes Lanero, con introducción y aparato crítico de Victorino Capanaga (Obras Completas de San Agustín, Vols. XVI y XVII, La Ciudad de Dios $1^{\circ}$ y $2^{\circ}$, Biblioteca de Autores Cristianos, cuarta edición, 1988). Las notas al pie de página incluidas en las páginas siguientes son de mi confección, para lo cual me he apoyado en la edición ya mencionada y en las ediciones en inglés de R. W. Dyson (Cambridge University Press, 1998) y de David Knowles (Penguin Books, 1981). Las referencias bíblicas han sido verificadas en la Biblia de Jerusalén (Editorial Desclée de Brouwer, S.A., 1976). Por supuesto, todos los errores de edición son de exclusiva responsabilidad mía. Al final de la selección se incluye una bibliografía de las obras citadas.

\footnotetext{
30 Sobre esta concepción limitada de lo político, véase Elshtain (1995).

31 Entrevista no publicada a Foucault en la que Robert Bellah hace notar algunas similitudes entre el pensamiento de Foucault y el cristianismo. La frase en inglés con la que Bellah sugiere la huella cristiana en la obra de Foucault —la que, a propósito, Foucault admite - es la siguiente: "being pessimistic without being hopeless". Citado en Schuld (2003), p. 1.
} 
LA CIUDAD DE DIOS, DE AGUSTÍN DE HIPONA

\section{LIBRO I}

\section{PRÓLOGO}

\section{MOTIVO Y ARGUMENTO DE LA PRESENTE OBRA}

La gloriosísima ciudad de Dios, que en el presente correr de los tiempos se encuentra peregrina entre los impíos viviendo de la fe ${ }^{1}$, y espera ya ahora con paciencia ${ }^{2}$ la patria definitiva y eterna hasta que haya un juicio con auténtica justicia ${ }^{3}$, conseguirá entonces con creces la victoria final y una paz completa. Pues bien, mi querido hijo Marcelino ${ }^{4}$, en la presente obra, emprendida a instancias tuyas, y que te debo por promesa personal mía, me he propuesto defender esta ciudad en contra de aquellos que anteponen los propios dioses a su fundador. ¡Larga y pesada tarea ésta! Pero Dios es nuestra ayuda 5 .

Soy consciente de la fuerza que necesito para convencer a los soberbios del gran poder de la humildad. Ella es la que logra que su propia excelencia, conseguida no por la hinchazón del orgullo humano, sino por ser don gratuito de la divina gracia, trascienda todas las eminencias pasajeras y vacilantes de la tierra. El Rey y fundador de esta ciudad, de la que me he propuesto hablar, declaró en las Escrituras de su pueblo el sentido de aquel divino oráculo que dice: Dios resiste a los soberbios y da su gracia a los humildes ${ }^{6}$. Pero esto mismo, que es privilegio exclusivo de Dios, pretende apropiárselo para sí el espíritu hinchado de soberbia, y le gusta que le digan para alabarle: "Perdonarás al vencido y abatirás al soberbio"7.

\footnotetext{
${ }^{1}$ Habacuc 2,4; Romanos 1,17; Gálatas 3,11; Hebreos 10,37-38.

${ }^{2}$ Romanos 8,25.

${ }^{3}$ Salmos 94,15 .

${ }^{4}$ La extensa correspondencia entre Agustín y su amigo Marcelino incluye muchos temas que anticipan aquéllos tratados en La Ciudad de Dios, ya que Marcelino le transmite la reacción de algunos paganos miembros de su círculo a la invasión de Roma por los visigodos liderados por Alarico en el año 410. En la carta 138, Agustín le anuncia la posibilidad de escribir un libro en respuesta a los reclamos de los paganos. Véase Obras de San Agustín VIII, Cartas (1. ${ }^{\circ}$ ) (1967), p. 976. Para mayor información sobre Marcelino, véase la excelente nota complementaria [1] en Obras de San Agustín XVI, La Ciudad

${ }^{5}$ Salmos 62,9; Salmos 118,6.

${ }^{6}$ Santiago 4,6; 1 Pedro 5,5; Proverbios 3,34.

${ }^{7}$ Virgilio, Eneida, 6,853 (2000, p. 191). Virgilio (70-19 a.C.), autor de las Églogas (o Bucólicas), las Geórgicas y la Eneida. Esta última obra es un poema épico que trata de la mítica fundación de Roma por Eneas y los troyanos sobrevivientes de la guerra de Troya. Es el texto poético más citado en La Ciudad de Dios, y, como en este pasaje, normalmente es utilizado para establecer que, incluso las obras más refinadas y admirables de autores paganos, son inferiores en su perspectiva moral que los principios cristianos contenidos principalmente en la Biblia. Véase O’Daly (1999), pp. 246-248.
} de Dios $\left(1^{\circ}\right)$ (1988), p. 816. 
Tampoco hemos de pasar por alto la ciudad terrena; en su afán de ser dueña del mundo, $\mathrm{y}$, aun cuando los pueblos se le rinden, ella misma se ve esclava de su propia ambición de dominio. De ello hablaré según lo pide el plan de la presente obra y mis posibilidades lo permitan.

\section{CAPÍTULO I}

LOS ENEMIGOS DEL NOMBRE DE CRISTO OBTIENEN EL PERDÓN DE LOS BÁRBAROS, POR REVERENCIA A CRISTO, DURANTE LA DEVASTACIÓN DE ROMA

De esta ciudad terrena surgen los enemigos contra quienes hay que defender la ciudad de Dios. Muchos de ellos, apartándose de sus errores impíos, se convierten en moradores bastante laudables de esta ciudad. Otros muchos, en cambio, se están abrasando en un odio tan violento contra ella, y son tan ingratos a los evidentes favores de su Redentor, que éste es el día en que no serían capaces de mover su lengua contra esta ciudad si no fuera porque encontraron en sus lugares sagrados, al huir de las armas enemigas, la salvación de su vida, de la que ahora tanto se enorgullecen. ¿O es que no son enemigos encarnizados de Cristo aquellos romanos a quienes los bárbaros, por respeto a Cristo, les perdonaron la vida? Testigos son de ello los santuarios de los mártires y las basílicas de los Apóstoles, que en aquella devastación de la gran Urbe acogieron a cuantos en ella se refugiaron, tanto propios como extraños ${ }^{8}$. Allí se moderaba la furia encarnizada del enemigo; allí ponía fin el exterminador a su saña; allí conducían los enemigos, tocados de benignidad, a quienes, fuera de aquellos lugares, habían perdonado la vida, y los aseguraban de las manos de quienes no tenían tal misericordia. Incluso aquellos mismos que en otras partes, al estilo de un enemigo, realizaban matanzas llenas de crueldad, se acercaban a estos lugares en los que estaba vedado lo que por derecho de guerra se permite en otras partes, refrenaban toda la saña de su espada y renunciaban al ansia que tenían de hacer cautivos.

De esta manera han escapado multitud de los que ahora desacreditan el cristianismo, y achacan a Cristo las desgracias que tuvo que soportar aquella ciudad. En cambio, el beneficio de perdonárseles la vida por respeto a Cristo no se lo atribuyen a nuestro Cristo, sino a su Destino. Deberían más bien, con un poco de juicio, atribuir los sufrimientos y asperezas que les han infligido sus enemigos a la divina Providencia, que suele

\footnotetext{
${ }^{8}$ Agustín se refiere a que las tropas de Alarico por lo general respetaron la vida de aquéllos, fieles o paganos, que buscaron refugio en los templos cristianos y lugares sagrados.
} 
acrisolar y castigar la vida corrompida de los humanos. Ella es quien pone a prueba la rectitud y la vida honrada de los mortales con estos dolores para, una vez probada, pasarla a vida mejor, o bien retenerla en esta tierra con otros fines.

Pero de hecho los bárbaros, en su ferocidad, les han perdonado la vida, contra el estilo normal de las guerras, por respeto al nombre de Cristo, sea en lugares comunes, sea en los recintos consagrados a su culto, y, para que fuera aún más abundante la compasión, eligieron los más amplios, destinados a reunir multitudes. Este hecho deberían atribuirlo al cristianismo. He aquí la necesaria ocasión para dar gracias a Dios y recurrir a su nombre con sinceridad, evitando las penas del fuego eterno, ellos que en masa escaparon de las presentes calamidades usando hipócritamente ese mismo nombre. Porque muchos de los que ves ahora insultar a los siervos de Cristo, con insolente desvergüenza, no hubieran escapado de aquella carnicería desastrosa si no hubieran fingido ser siervos de Cristo. Y ahora, joh soberbia desagradecida y despiadada locura!, se hacen reos de las eternas tinieblas oponiéndose con perverso corazón a su nombre, nombre al cual un día se acogieron, con labios engañosos, para gozar de la luz temporal.

\section{CAPÍTULO XXIX}

\section{RESPUESTA DE LA FAMILIA CRISTIANA A LOS INFIELES CUANDO ÉSTOS LE ECHEN EN CARA QUE CRISTO NO LOS LIBRÓ DEL FUROR DE LOS ENEMIGOS}

Ya tiene, pues, la familia entera del sumo y verdadero Dios su propio consuelo, y un consuelo no falaz ni fundamentado en la esperanza de bienes tambaleantes o pasajeros. Ya no tiene en absoluto por qué estar pesarosa ni siquiera de la misma vida temporal, puesto que en ella aprende a conseguir la eterna, y, como peregrina que es, hace uso, pero no cae en la trampa, de los bienes terrenos; y en cuanto a los males, o es en ellos puesta a prueba, o es por ellos corregida. Y los paganos, que, con ocasión de sobrevivir tal vez a algunos infortunios temporales, insultan su honor, gritándoles: ¿Dónde está tu Dios?⿳9一𠃌 que digan ellos dónde están sus dioses, puesto que están padeciendo precisamente aquellas calamidades que, para evitarlas, les tributan culto o pretenden que hay que tributárselo.

He aquí la respuesta de la familia cristiana: Mi Dios está presente en todas partes; en todas partes está todo Él; no está encerrado en ningún lugar: puede hallarse cerca sin que lo sepamos, y puede ausentarse sin

\footnotetext{
${ }^{9}$ Salmos 42,4 .
} 
movimiento alguno. Cuando me azota con la adversidad, está sometiendo a prueba mis méritos o castigando mis pecados. Yo sé que me tiene reservada una recompensa eterna por haber tolerado religiosamente las desgracias temporales. Pero vosotros, ¿quiénes sois para merecer que se hable con vosotros ni siquiera de vuestros dioses, cuánto menos de mi Dios, que es más temible que todos los dioses, pues los dioses de los gentiles son demonios, mientras que el Señor ha hecho el cielo ${ }^{10}$

\section{CAPÍTULO XXX $\mathrm{XX}^{11}$ \\ LOS QUE SE QUEJAN DEL CRISTIANISMO ESTÁN DESEANDO REBOSAR EN PROSPERIDADES VERGONZOSAS}

Si todavía estuviese vivo el famoso Escipión Nasica, en otro tiempo vuestro pontífice, elegido unánimemente por el Senado como el hombre más virtuoso para recibir la sagrada imagen de Frigia bajo el terror de la guerra púnica $^{12}$, no os atreveríais quizá a mirarle al rostro; sería él en persona quien frenaría vuestra actual desvergüenza: ¿Por qué os quejáis del cristianismo cuando os azota la adversidad? ¿No es porque estáis deseando gozar con seguridad de vuestros excesos y nadar en las aguas corrompidas de vuestras inmoralidades, lejos de toda molestia incómoda? Anheláis tener paz y estar sobrados de toda clase de recursos, pero no es para hacer uso de ellos con honradez, es decir, con moderación y sobriedad, con templanza y según las exigencias de la religión, sino para procuraros la más infinita gama de placeres con despilfarros insensatos, y en tal prosperidad dar origen en vuestra conducta a unas depravaciones peores que la crueldad de los enemigos.

Pero este vuestro querido Escipión, pontífice máximo, declarado como el hombre más honrado de la República por el Senado en pleno, temía que os iba a sobrevenir esta desgracia, y por eso rechazaba la destrucción de Cartago, rival entonces del poder romano, y se oponía a Catón, que

\footnotetext{
10 Salmos 96,4-5.

${ }^{11}$ En los capítulos XXX y XXXI del primer libro es notoria la influencia del historiador y político romano Salustio (86-34 a.C.) en cuanto a la degradación moral de Roma como efecto de la conquista de su imperio. Véase O’Daly (1999), pp. 79-80, y pp. 240-246.

12 Tito Livio, Historia de Roma desde su Fundación 29, 14 (2001, p. 318). El historiador romano Tito Livio (59 a.C.-17 d.C.) es junto con Salustio una de las fuentes históricas más importantes en La Ciudad de Dios. Véase O’Daly (1999), pp. 248-249. El término "pontífice" obviamente no se refiere a los papas de la Iglesia católica, sino a los sacerdotes superiores de la religión pagana en Roma, y quienes cumplían funciones tanto políticas como religiosas.
} 
abogaba por su ruina ${ }^{13}$. Temía la seguridad para los espíritus débiles como a un enemigo, y veía que era necesario el terror como tutor, adecuado para esta especie de ciudadanos menores.

No se equivocó Escipión: fue la realidad quien le dio toda la razón. En efecto, destruida Cartago, es decir, alejado y desaparecido de Roma el terror, inmediatamente comenzaron a surgir, como consecuencia de la situación próspera, enorme cantidad de lacras: la concordia mutua se resquebrajó y llegó a romperse. Primeramente por rebeliones encarnizadas y sangrientas, e inmediatamente después por una complicación de sucesos desafortunados, incluso con guerras civiles, se produjeron tales desastres, se derramó tanta sangre, se encendió un tal salvajismo con avidez de destierros y rapiñas, que los romanos, aquellos que en tiempos de su vida más íntegra temían desgracias por parte del enemigo; ahora, echada a perder esa integridad de conducta, tenían que padecer mayores crueldades de sus propios compatriotas. La misma ambición de poder, uno de tantos vicios del género humano, pero arraigado con mucha más fuerza en las entrañas de todo el pueblo romano, una vez vencidas algunas de las principales potencias, aplastó bajo el yugo de su servidumbre a las restantes, ya deshechas y fatigadas.

\section{CAPÍTULO XXXI}

\section{LA CORRUPCIÓN, EN UNA CONSTANTE ESCALADA, IMPULSÓ EN LOS ROMANOS} LA PASIÓN DE DOMINIO

¿Y cuándo iba a quedar satisfecha tal ambición en estos espíritus tan orgullosos, más que cuando llegasen a poseer el dominio absoluto, tras escalar todos los honores? En efecto, no habría la posibilidad de continuar manteniendo tales honores si no hubiera una ambición superior. Pero jamás la ambición se adueñaría si no es en un pueblo corrompido por la avaricia y el desenfreno. Y en avaro y desenfrenado se convirtió el pueblo romano por la prosperidad, aquella prosperidad de la que el famoso Nasica, con penetrante visión de futuro, opinaba que se debía evitar, oponiéndose a la destrucción del mayor, el más fuerte y más opulento estado rival. De esta manera el temor reprimiría la pasión; con la pasión, así reprimida, no se caería en el desenfreno; y contenido éste, no asomaría la avaricia. Teniendo

${ }^{13}$ En estos capítulos Agustín confunde a Escipión Nasica con su hijo Escipión Corculum. El primero fue escogido para traer la imagen de Frigia, pero fue el segundo quien se opuso a Catón (234-149 a.C., "el censor") en cuanto a la destrucción de Cartago, y el que prohibió la construcción del teatro siendo cónsul en 155 a.C. Véase Tito Livio, Libro Historia de Roma desde su Fundación, XIX, 13-14 (2001, p. 316-319). 
atajados estos vicios florecería y se incrementaría la virtud, tan útil a la patria. La libertad, compañera de la virtud, estaría siempre presente.

Por esta misma razón y por el amor tan previsor a su patria, este vuestro pontífice máximo en persona, designado —no lo repetiremos nunca bastante- con plena unanimidad por el Senado de su tiempo como el hombre más honrado, hizo que el mismo Senado retirase su proyecto, tan ansiado, de construir un teatro. En su discurso, lleno de gravedad, logró persuadirles a que no consintieran la infiltración de la molicie griega en la conducta varonil de su patria y no tolerasen el desmoronamiento y la muerte de la virtud romana por causa de una advenediza depravación. Fue tal el poder de sus palabras, que el Senado cambió sus disposiciones: prohibió que en adelante se colocaran los asientos, que ya empezaba la ciudad a ordenar en grupos, a la hora del espectáculo de los juegos ${ }^{14}$.

¡Con qué celo no habría desterrado de Roma este hombre hasta los mismos juegos escénicos si hubiera osado resistir a la autoridad de los que creía dioses! No se daba cuenta de que eran funestos demonios, o, si lo sabía, más bien pensaba se les debía aplacar que menospreciar. Todavía no se había hecho luz ante los gentiles sobre aquella doctrina de lo alto, que pudiera cambiar las aspiraciones humanas, y, limpiando el corazón por la fe, tendiese a los bienes celestes y supracelestes con humilde espíritu religioso, quedando liberado de la tiranía de los hinchados demonios.

\section{CAPÍTULO XXXV15}

\section{EN MEDIO DE LOS PAGANOS HAY HIJOS DE LA IGLESIA, Y DENTRO DE LA IGLESIA HAY FALSOS CRISTIANOS}

Estas y otras semejantes respuestas, y posiblemente con más elocuencia y soltura, podrán responder a sus enemigos los miembros de la familia de Cristo, el Señor, y de la peregrina ciudad de Cristo Rey. Y no deben perder de vista que entre esos mismos enemigos se ocultan futuros

${ }^{14}$ Esta reflexión respecto de la mala influencia sobre las costumbres y la inducción al vicio de los teatros tiene como referente la propia experiencia de Agustín en su juventud, durante la cual fue adepto a asistir a representaciones teatrales (Véase Confesiones, III, 2 (1947, pp. 156-159)). Por cierto la línea de argumentación en estos pasajes es muy similar a la que presentará Jean-Jacques Rousseau en su Carta a D’Alembert sobre el teatro. La influencia de Agustín sobre Rousseau es patente, y ciertamente va más allá del título, Confesiones, de sus respectivos textos autobiográficos. Para un análisis de esta influencia, véase Brooke (2001) y Riley (1986).

${ }^{15}$ En este penúltimo capítulo del Libro I, Agustín adelanta lo que será uno de los temas principales de la obra, y el que es desarrollado especialmente en el Libro XIX, es decir, la imposibilidad de distinguir, en este mundo, a los miembros de la Ciudad de Dios, de los de la Ciudad Terrena. 
compatriotas, no vayan a creer infructuoso el soportar como ofensores a los mismos que quizá un día los encuentren proclamadores de su fe. Del mismo modo sucede que la ciudad de Dios tiene, entre los miembros que la integran mientras dura su peregrinación en el mundo, algunos que están ligados a ella por la participación en sus misterios, y, sin embargo, no participarán con ella la herencia eterna de los santos. Unos están ocultos, otros manifiestos. No dudan en hablar, incluso unidos a los enemigos, contra Dios, de cuyo sello sacramental son portadores. Tan pronto se encuentran entre la multitud pagana, que llena los teatros, como entre nosotros en las iglesias. No hay por qué desesperar en la enmienda de algunos, incluso de estos últimos, mucho menos cuando entre nuestros enemigos más declarados se ocultan algunos predestinados a ser nuestros amigos, y que ni ellos mismos lo saben. Entrelazadas, de hecho, y mezcladas mutuamente están estas dos ciudades, hasta que sean separadas en el último juicio.

Voy a exponer mi opinión sobre el origen de ambas, su proceso evolutivo y el final que les corresponde, según la ayuda que reciba de Dios; todo a gloria de la ciudad de Dios, que brillará con más claridad en contraste con sus opuestos.

\section{LIBRO II}

\section{CAPÍTULO XXI}

Opinión DE Cicerón SOBRE ROMA

1. Pero si no se hace caso de quien ha llamado a Roma corrompida y envilecida en extremo, y les da lo mismo que esté cubierta por un baldón vergonzoso de inmoralidad y de ignominia, con tal que se tenga en pie y siga adelante, presten atención no a que se hizo, como nos cuenta Salustio, corrompida y envilecida, sino, como aclara Cicerón ${ }^{16}$, a que ya entonces estaba completamente en ruinas y no quedó ni rastro de la República.

Pone en escena Cicerón al mismo Escipión ${ }^{17}$, que había hecho desaparecer a Cartago, disputando sobre Roma, en una época en que, por efecto de la corrupción descrita por Salustio, se presentía a muy corto plazo

${ }^{16}$ Marco Tulio Cicerón (106-43 a.C.), político y filósofo romano, cónsul en el 63 a.C. Para la importancia de Cicerón, y de esta discusión sobre la importancia de la justicia en una república bien ordenada, véase O’Daly (1999), pp. 238-240. También véase el excelente artículo de Velásquez (2001).

${ }^{17}$ Publio Escipión Emiliano Africano Numantino (184-129 a.C.), personaje principal del diálogo de Cicerón, Sobre la República (1991), en el que Filo y Lelio son sus interlocutores. Este Escipión, distinto a los mencionados anteriormente por Agustín, estuvo a cargo de la tercera guerra púnica, y obtuvo fama como destructor de Cartago. 
su ruina. En efecto, la discusión se sitúa en el momento en que había sido asesinado uno de los $\mathrm{Gracos}^{18}$, el que dio origen, según Salustio, a las graves escisiones que surgieron. De esta muerte se hace eco su misma obra. Había dicho Escipión al final del segundo libro: "Entre la cítara o las flautas y el canto de voces debe haber una cierta armonía de los distintos sonidos, y si falta la afinación o hay desacordes, es insufrible para el oído entendido. Pero también esa misma armonía se logra mediante un concierto ordenado y artístico de las voces más dispares. Pues bien, de este mismo modo, concertando debidamente las diversas clases sociales, altas, medias y bajas, como si fueran sonidos musicales, y en un orden razonable, logra la ciudad realizar un concierto mediante el consenso de las más diversas tendencias. Diríamos que lo que para los músicos es la armonía en el canto, eso es para la ciudad la concordia, vínculo el más seguro, y el mejor para la seguridad de todo Estado. Y, sin justicia, de ningún modo puede existir la concordia”"19.

Pasa luego a exponer con más detención y profundidad la importancia de la justicia para una ciudad, así como el enorme perjuicio de su falta. A continuación toma la palabra Filo, uno de los que asisten a la discusión, y solicita que este tema sea tratado con más detenimiento, y que se hable más extensamente de la justicia, por aquello de que un Estado —así dice la gente- no es posible gobernarlo sin injusticia. Escipión, pues, da su consentimiento con vistas a discutir y aclarar el tema. Su respuesta es que de nada serviría todo lo tratado hasta ahora sobre el Estado, y sería inútil dar un paso más si no queda bien sentado no sólo la falsedad del principio anterior: "Es inevitable la injusticia", sino la absoluta verdad de este otro: "Sin la más estricta justicia no es posible gobernar un Estado"20.

Se aplazó para el día siguiente su explicación, y en el libro tercero la materia está tratada muy acaloradamente. Filo tomó en la disputa el partido de quienes opinan que no es posible gobernar sin injusticia, dejando bien claro que su opinión personal era muy otra, y con toda claridad empezó a defender la injusticia contra la justicia, como si tratase realmente de demostrar con ejemplos y aproximaciones que aquélla era de interés para el Estado, y ésta, en cambio, de nada le servía. Entonces, a ruegos de todos, emprendió Lelio la defensa de la justicia, afirmando, con toda la intensidad que pudo, que nada hay tan enemigo de una ciudad como la injusticia, y que jamás un Estado podrá gobernarse o mantenerse firme si no es con una estricta justicia. Escipión

${ }^{18}$ Políticos romanos partidarios de profundas reformas agrarias, adversarios de

${ }^{19}$ Cicerón, Sobre la República, 2, $42-43$ (1991, p. 122).

${ }^{20}$ Ibid., 2, 44 (1991, p. 123). 
2. Pareció este tema suficientemente tratado, con lo que Escipión reanuda su interrumpido discurso. Evoca y encarece su breve definición de república: es "una empresa del pueblo", había dicho él. Y puntualiza que "pueblo" no es cualquier grupo de gente, sino "la asociación de personas basada en la aceptación de unas leyes y en la comunión de intereses"21. Muestra después la gran utilidad de una definición a la hora de discutir, y concluye de su definición que sólo se da un Estado ("República”), es decir, una "empresa del pueblo", cuando se gobierna con rectitud y justicia, sea por un rey, sea por una oligarquía de nobles, sea por el pueblo entero. Pero cuando el rey es injusto, él le llama "tirano", al estilo griego; cuando lo son los nobles dueños del poder, les llama "facción", y cuando es injusto el mismo pueblo, al no encontrar otro nombre usual, llama también "tirano" al pueblo. Pues bien, en este caso no se trata ya — dice él— de que la República esté depravada, como se decía en la discusión del día anterior; es que así ya no queda absolutamente nada de República, según la necesaria conclusión de tales definiciones, al no ser una "empresa del pueblo", puesto que un tirano o una facción la han acaparado, y, por tanto, el pueblo mismo ya no es pueblo si es injusto: no sería una "asociación de personas, basada en la aceptación de unas leyes y en la comunión de intereses”, según la definición de "pueblo".

3. Por eso, cuando la República estaba tal como la describe Salustio ${ }^{22}$, no era ya la más corrompida e infame, como él dice, sino que ya no existía en absoluto, como lo demuestran con toda evidencia las razones de la discusión que sobre el Estado tuvieron los personajes más relevantes de aquel entonces. Como también el mismo Tulio ${ }^{23}$, no ya por boca de Escipión, sino con sus propias palabras, afirma en el comienzo del quinto libro, después de recordar aquel verso del poeta Ennio: "Si Roma subsiste es gracias a sus costumbres tradicionales y héroes antiguos"24. "Verso este — dice- que, por su concisión y veracidad, podría perfectamente haber sido proferido por algún oráculo de antaño. En efecto, ni estos héroes sin una morigerada ciudad, ni las buenas costumbres sin el caudillaje de tales héroes, hubieran sido capaces de fundar ni de mantener por mucho tiempo un Estado tan poderoso y con un dominio tan extendido por toda la geogra-

\footnotetext{
21 Ibid., 1, 25 (1991, pp. 62-63).

22 Salustio (86-34 a.C.), político e historiador romano. Autor de Conjuración de Catilina, Guerra de Jugurta e Historias. Agustín lo cita muchas veces y por lo general con el objeto de reproducir sus juicios relativos a la corrupción y declive moral durante los últimos tiempos de la república romana. Véase O’Daly (1999), pp. 240-246.

23 Tulio es el mismo Cicerón.

24 Cicerón, Sobre la República, 5,1 (1999, p. 151). Ennio (239-169 a.C.), poeta romano. Cicerón toma este verso de sus Anales.
} 
fía. Así, en tiempos pasados la propia conducta ciudadana proporcionaba hombres de prestigio, y estos excelentes varones mantenían las costumbres antiguas y las tradiciones de los antepasados. En cambio, nuestra época ha recibido el Estado como si fuera un precioso cuadro, pero algo desvaído por su antigüedad. Y no solamente se ha descuidado en restaurarlo a sus colores originales, sino que ni se ha preocupado siquiera de conservarle los contornos de su silueta. ¿Qué queda de aquellas viejas costumbres que mantenían en pie — dice el poeta — el Estado romano? Tan enmohecidas las vemos del olvido, que no sólo no se las fomenta, sino que ya ni se las conoce. Y de los hombres, ¿qué diré? Precisamente por falta de hombría han perecido aquellas costumbres. Desgracia tamaña ésta de la que tendremos que rendir cuentas; más aún, de la que de algún modo tendremos que excusarnos en juicio, como reos de pena capital. Por nuestros vicios, no por una mala suerte, mantenemos aún la República como una palabra. La realidad, mucho tiempo ha que la hemos perdido.”

4. Esto confesaba Cicerón mucho después, es verdad, de la muerte de "el Africano"25, haciéndole discutir sobre el Estado en su obra, pero ciertamente antes de la venida de Cristo. Si estos pareceres hubieran sido expresados después de la difusión y victoria del cristianismo, ¿qué pagano dejaría de imputar tal decadencia a los cristianos? ¿Y por qué entonces los dioses no se preocuparon de que no pereciese y se perdiera aquella República que Cicerón, mucho antes de la venida de Cristo en carne mortal, con acentos tan lúgubres deplora haber sucumbido? Miren a ver los admiradores que ella tiene, cómo fue incluso en la época de antiguos héroes y viejas costumbres, a ver si estaba vigente la auténtica justicia, o tal vez ni siquiera entonces estuviera viva por sus costumbres, sino apenas pintada de colores, cosa que el mismo Cicerón, sin pretenderlo, expresó al exaltarla. Pero esto, si Dios quiere, lo trataremos en otro lugar ${ }^{26}$.

Me esforzaré en su momento por demostrar que aquél no fue nunca Estado auténtico ("República”), porque en él nunca hubo auténtica justicia. Y esto lo haré apoyándome en las definiciones del mismo Cicerón, según las cuales él brevemente, por boca de Escipión, dejó sentado qué es el Estado y qué es el pueblo (apoyándolo también en otras muchas afirmaciones suyas y de los demás interlocutores de la discusión). En rigor, si seguimos las definiciones más autorizadas, fue, a su manera, una república, y mejor gobernada por los viejos romanos que por los más recientes. La verdadera justicia no existe más que en aquella república cuyo fundador y gobernador es Cristo, si es que a tal Patria nos parece bien llamarla así, república, puesto

25 "El Africano" es Escipión.

${ }^{26}$ Se refiere al libro XIX, capítulo 21, incluido en esta selección. 
que nadie podrá decir que no es una "empresa del pueblo". Y si este término, divulgado en otros lugares con una acepción distinta, resulta quizá inadecuado a nuestra forma usual de expresarnos, sí es cierto que hay una auténtica justicia en aquella ciudad de quien dicen los Sagrados Libros: ¿Qué pregón tan glorioso para ti, Ciudad de Dios! ${ }^{27}$

\section{LIBRO IV}

\section{CAPÍTULO III}

EL ENGRANDECIMIENTO DEL ESTADO, LOGRADO SOLAMENTE MEDIANTE LAS GUERRAS, ¿DEBE CONSIDERARSE COMO UNO DE LOS BIENES DE LA SABIDURÍA O DE LA FELICIDAD?

Pasemos ya a considerar el peso de las razones que asisten a los paganos para que tengan la osadía de atribuir la gran amplitud y la larga duración de la dominación romana a esos dioses, cuyo culto se empeñan en llamar honesto, cuando ha sido realizado por medio de representaciones escénicas envilecidas, y a través de hombres no menos envilecidos. Quisiera antes, no obstante, hacerme una breve pregunta: ¿Cuáles son las razones lógicas o políticas para querer gloriarse de la duración o de la anchura de los dominios del Estado? Porque la felicidad de estos hombres no la encuentras por ninguna parte, envueltos siempre en los desastres de la guerra, manchados sin cesar de sangre, conciudadana o enemiga, pero humana; envueltos constantemente en un temor tenebroso, en medio de pasiones sanguinarias; con una alegría brillante, sí, como el cristal, pero como él, frágil, bajo el temor horrible de quebrarse por momentos. Para enjuiciar esta cuestión con más objetividad, no nos hinchemos con jactanciosas vaciedades, no dejemos deslumbrarse nuestra agudeza mental por altisonantes palabras, como "pueblos”, “reinos”, "provincias”. Imaginemos dos hombres (porque cada hombre, a la manera de una letra en el discurso, forma como el elemento de la ciudad y del Estado, por mucha que sea la extensión de su territorio). De estos dos hombres, pongamos que uno es pobre, o de clase media, y el otro riquísimo. El rico en esta suposición vive angustiado y lleno de temores, consumido por los disgustos, abrasado de ambición, en perpetua inseguridad, nunca tranquilo, sin respiro posible por el acoso incesante de sus enemigos; aumenta, por supuesto, su fortuna hasta lo indecible, a base de tantas desdichas, pero, a su vez, creciendo en la misma proporción el cúmulo de amargas preocupaciones. El otro, en cambio, de mediana posición, se basta con su fortuna, aunque pequeña y ajustada; los suyos le

${ }^{27}$ Salmos, 87,3. 
quieren mucho, disfruta de una paz envidiable con sus parientes, vecinos y amigos; es profundamente religioso, de gran afabilidad, sano de cuerpo, moderado y casto en sus costumbres; vive con la conciencia tranquila. ¿Habrá alguien tan fuera de sus cabales, que dude a quién de los dos preferir? Pues bien, lo que hemos dicho de dos hombres lo podemos aplicar a dos familias, dos pueblos, dos reinos. Salvando las distancias, podremos deducir con facilidad dónde se encuentran las apariencias y dónde la felicidad.

Así, pues, cuando al Dios verdadero se le adora, y se le rinde un culto auténtico y una conducta moral intachable, es ventajoso que los buenos tengan el poder durante largos períodos sobre grandes dominios. Y tales ventajas no lo son tanto para ellos mismos cuanto para sus súbditos. Por lo que a ellos concierne, les basta para su propia felicidad con la bondad y honradez. Son éstos dones muy estimables de Dios para llevar aquí una vida digna y merecer luego la eterna. Porque en esta tierra, el reinado de los buenos no es beneficioso tanto para ellos cuanto para las empresas humanas. Al contrario, el reinado de los malos es pernicioso sobre todo para los que ostentan el poder, puesto que arruinan su alma por una mayor posibilidad de cometer crímenes. En cambio, aquellos que les prestan sus servicios sólo quedan dañados por la propia iniquidad. En efecto, los sufrimientos que les vienen de señores injustos no constituyen un castigo de algún delito, sino una prueba de su virtud. Consiguientemente, el hombre honrado, aunque esté sometido a servidumbre, es libre. En cambio, el malvado, aunque sea rey, es esclavo, y no de un hombre, sino de tantos dueños como vicios tenga ${ }^{28}$. De estos vicios se expresa la divina Escritura en estos términos: Cuando uno se deja vencer por algo, queda hecho su esclavo ${ }^{29}$.

\section{CAPÍTULO IV}

\section{SEMEJANZA ENTRE LAS BANDAS DE LADRONES Y LOS REINOS INJUSTOS}

Si de los gobiernos quitamos la justicia, ¿en qué se convierten sino en bandas de ladrones a gran escala? Y estas bandas, ¿qué son sino reinos en pequeño? Son un grupo de hombres, se rigen por un jefe, se comprome-

${ }^{28}$ Este pasaje, y este capítulo en general, tienen relación directa con la concepción de libertad, y de libre albedrío, de gran importancia en el pensamiento de Agustín. La libertad, en su sentido más profundo, no depende de los regímenes políticos, sino de la capacidad para vivir rectamente, la que se deriva de la gracia divina. El libre albedrío no desaparece de la naturaleza humana con el pecado, sino que la voluntad se hace instrumento del mal, y por ende se es esclavo de los vicios. En este sentido, la gracia divina "libera" a los seres humanos al desencadenarlos del mal.

${ }^{29} 2$ Pedro 2,19. 
ten en pacto mutuo, reparten el botín según la ley por ellos aceptada. Supongamos que a esta cuadrilla se la van sumando nuevos grupos de bandidos y llega a crecer hasta ocupar posiciones, establecer cuarteles, tomar ciudades y someter pueblos: abiertamente se autodenomina reino, título que a todas luces le confiere no la ambición depuesta, sino la impunidad lograda. Con toda finura y profundidad le respondió al célebre Alejandro Magno un pirata caído prisionero. El rey en persona le preguntó: “¿Qué te parece tener el mar sometido al pillaje?” "Lo mismo que a ti —respondió- el tener el mundo entero. Sólo que a mí, como trabajo con una ruin galera, me llaman bandido, y a ti, por hacerlo con toda una flota, te llaman emperador"30.

\section{LIBRO V \\ CAPÍTULO VIII}

HAY QUIENES DAN EL NOMBRE DE DESTINO NO A LA POSICIÓN DE LOS ASTROS, SINO A LA CONCATENACIÓN DE CAUSAS QUE PENDEN DE LA VOLUNTAD DE DiOS

Hay filósofos que con el nombre de destino no se refieren a la posición de los astros en el momento de la concepción, o del nacimiento, o del comienzo de algo. Sencillamente hacen referencia a la serie de todas las causas concatenadas que originan cuanto sucede ${ }^{31}$. No vale la pena entablar una laboriosa controversia por causa de una palabra. De hecho, la ordenación de las causas y una cierta concatenación de las mismas la atribuyen a la voluntad y al poder del Dios supremo, de quien creemos, con el mayor acierto y la más plena verdad, que lo sabe todo antes de que suceda, y que no deja nada en desorden; de Él nace todo poder, aunque no nace todo querer.

La prueba de que con el nombre de destino entienden principalmente la voluntad misma del Dios sumo, cuyo poder se extiende a todas las cosas indefectiblemente, está en los siguientes versos, que, si mal no recuerdo, son de Anneo Séneca: "Condúceme, Padre soberano, dueño de las alturas celestes, a donde bien te plazca. Obedeceré sin demora. ¡Heme aquí presto! Haz que yo no quiera; te seguiré con llanto, y, aunque malo, soportaré lo

${ }^{30}$ Esta es una versión ampliada de la historia contada por Cicerón, Sobre la República, 3, 14 (1991, p. 133). La relevancia de ella al engrandecimiento de Roma a través de la conquista es evidente.

${ }^{31}$ Se hace referencia aquí a la doctrina determinista de los estoicos. Véase A. A. Long (1986), pp. 164-170; también véase la selección de textos y comentario en Long y Sedley (1992), pp. 333-343. 
que el bueno hace con agrado: lleva de la mano el destino al que obedece, y fuerza al que se resiste"32.

Es evidente que en el último verso llama destino a lo que poco antes acaba de llamar "voluntad del Padre soberano". Se muestra dispuesto a obedecerle, quiere ser conducido voluntariamente para no ser arrastrado por la fuerza, ya que "lleva el destino de la mano al que obedece, y fuerza al que se resiste". Vienen a apoyar esta sentencia aquellos versos de Homero, traducidos al latín por Cicerón: "Son las almas de los hombres como la luz con que el padre Júpiter quiso él mismo iluminar la tierra fecunda”33.

Ningún peso tendrían en esta cuestión las opiniones de los poetas. Pero se da la circunstancia de que — según Cicerón — los estoicos, para defender la fatalidad, suelen citar estos versos de Homero. No se trata, pues, ya del sentir de un poeta, sino de la opinión de dichos filósofos. Son estos versos los que utilizan en sus discursos sobre el destino, y a través de ellos manifiestan claramente lo que piensan sobre él, dado que llaman Júpiter al que creen ser el dios supremo, de quien pende, dicen, toda la trama de los destinos.

\section{CAPÍTULO IX}

\section{LA PRESCIENCIA DE DIOS Y LA LIBRE VOLUNTAD DEL HOMBRE, CONTRA LA FORMULACIÓN DE CICERÓN}

1. Cicerón hace esfuerzos para refutar a los estoicos; pero pone una condición: se siente impotente ante ellos mientras no quite de en medio la adivinación. Su afán por suprimirla estriba en negar la ciencia del futuro. Intenta por todos los medios negarla rotundamente: no existe - afirmapredicción alguna de los hechos ni en Dios ni en el hombre. Por esta vía rechaza la presciencia de Dios. Toda profecía, aun más clara que la luz del día, intenta echarla abajo con argumentaciones inconsistentes, y objetándose a sí mismo ciertos oráculos fáciles de refutar: pero ni siquiera lo consigue del todo.

A la hora de atacar a las teorías de los astrólogos, su retórica queda triunfante. En realidad, tales conjeturas son de tan baja categoría, que por sí mismas se desbaratan. No obstante, más tolerables, con diferencia, son los

32 Séneca (4 a.C.-65 d.C.), filósofo estoico, consejero del emperador Nerón. Fue obligado a suicidarse luego de ser acusado de conspirador. El pasaje aquí citado está contenido en la Epístola 107, 11 (2001, p. 286) y proviene originalmente del Himno a Zeus de Cleantes.

${ }^{33}$ Homero, Odisea, 18, 136-138 (2000, p. 294). Agustín nunca aprendió griego satisfactoriamente, y por ende su conocimiento de la cultura griega provino por lo general de traducciones. Véase Brown (1967), pp. 37 y 271. 
partidarios de los destinos astrales, que este Cicerón, que suprime el conocimiento del futuro. Porque admitir la existencia de Dios y negar que conozca el futuro es una incongruencia superlativa.

El mismo, al caer en la cuenta de esto, estuvo a punto de protagonizar aquella sentencia de la Escritura: Dice el necio para sí: "No hay Dios" ${ }^{34}$. Pero no lo puso en primera persona; le pareció que estaría mal visto, que sería incómodo, y le hace discutir a Cota sobre esta cuestión en contra de los estoicos en su obra De Natura Deorum ${ }^{35}$. Él prefiere ponerse de parte de Lucilio Balbo, a quien le encomienda defender la sentencia estoica, más bien que de parte de Cota, que intenta negar la existencia de toda naturaleza divina. En su obra De Divinatione ${ }^{36}$, él en persona ataca abiertamente el conocimiento del futuro. Los motivos que parecen impulsarle son el rechazo del destino fatal y la defensa de la libre voluntad. Piensa que, una vez admitida la ciencia del futuro, la fatalidad es una consecuencia tan necesaria como innegable.

Pero dejemos que los filósofos se pierdan a su gusto por los laberintos de sus debates y sus discusiones. Nosotros, al proclamar la existencia de un Dios supremo y verdadero, estamos confesando su voluntad, su soberano poder y su presciencia. Y no por eso tenemos miedo de hacer sin voluntad lo que voluntariamente hacemos: de antemano sabe ya Dios lo que vamos a hacer; su presciencia es infalible. Fue este temor el que llevó a Cicerón a impugnar la presciencia, y a los estoicos a negar que todo lo hacemos necesariamente, aunque ellos sostienen que el destino lo rige todo.

2. ¿Y cuáles son los temores de Cicerón ante la presciencia del futuro para que se empeñe en anularla en su detestable discusión? Helos aquí: si los hechos futuros son todos conocidos, han de suceder según el orden de ese previo conocimiento. Si han de suceder según ese orden, ya está determinado tal orden para Dios, que lo conoce de antemano. Ahora bien, un orden determinado de hechos exige un orden determinado de causas, ya que no puede darse hecho alguno sin una causa eficiente anterior. Y si el orden de las causas, por las que sucede todo cuanto sucede, está ya fijado, “todo sucede — afirma Cicerón — bajo el sino de la fatalidad”. Si esto es así, nada depende de nosotros, no existe el libre albedrío de la voluntad. "Si concedemos esto — prosigue—, se derrumba toda la vida humana: ¿para qué promulgar leyes? ¿Para qué reprender ni hablar, vituperar o exhortar? Se

\footnotetext{
${ }^{34}$ Salmos 14,1 .

${ }^{35}$ Cicerón, Sobre la Naturaleza de los Dioses (2000), libro III.

${ }^{36}$ Cicerón, Sobre la Adivinación; Sobre el Destino; Timeo, 2, 56 (1999).
} 
prescribirán premios para los buenos y castigos a los malos, pero sin justicia alguna" 37 .

Así, pues, para evitarle a la humanidad unas secuelas tan indignas, tan absurdas, tan perniciosas, se niega Cicerón a admitir la presciencia del futuro. De esta forma somete al espíritu religioso a un angustioso dilema: es necesario elegir una de estas dos realidades: o que algo dependa de nuestra voluntad, o que exista el conocimiento previo del futuro. Las dos cosas a la vez —opina él— son incompatibles; afirmar una es anular la otra: si elegimos la presciencia del futuro, hemos anulado el libre albedrío de la voluntad; si elegimos el libre albedrío, hemos anulado la presciencia del futuro.

Pero este gran hombre que es Cicerón, tan sabio, defensor tantas veces y con tanta maestría de los intereses de la humanidad, puesto en esta alternativa, elige el libre albedrío. Para dejarlo sólidamente establecido, nos hace ateos.

Sin embargo, el hombre que tiene espíritu religioso elige ambas cosas a la vez, confiesa ambas cosas y ambas cosas las fundamenta en la fe de su religión. ¿Cómo es posible, preguntará Cicerón? Porque, si se da el conocimiento de lo por venir, se sigue la concatenación de todas aquellas razones que nos hacen desembocar en que nada depende de nuestra voluntad. $\mathrm{Y}$ al revés, si admitimos que algo está en nuestra voluntad, los mismos argumentos, vueltos sobre sus pasos, nos llevan a demostrar que no hay presciencia del futuro. Veámoslo: si existe la libertad, hay acciones que caen fuera del destino. Si esto es así, tampoco está determinado el orden de todas las causas. Si el orden de las causas no está determinado, tampoco está determinado el orden de los hechos para el conocimiento previo de Dios, puesto que no pueden darse sin unas causas eficientes que los precedan. Y si el orden de los acontecimientos no está determinado en la presciencia de Dios, no todo sucederá como Él lo previó. Ahora bien, si no todo ha de suceder tal y como Él lo tenía previsto, luego no existe —concluye Cicerón- la presciencia en Dios de todos los futuros ${ }^{38}$.

3. Contra esta sacrílega e impía audacia nosotros afirmamos que Dios conoce todas las cosas antes de que sucedan, y que nosotros hacemos voluntariamente aquello que tenemos conciencia y conocimiento de obrar movidos por nuestra voluntad. No decimos que todo suceda por el destino; es más, afirmamos que nada ocurre bajo su influjo. La palabra destino, tal como se suele usar, es decir, la posición de los astros en el momento de la concepción del nacimiento de alguien, es una expresión sin contenido que de nada sirve, como ya hemos demostrado. En cuanto al orden de las cau-

\footnotetext{
${ }^{37}$ Ibid., $17,40$.

${ }^{38}$ Ibid., 10,20.
} 
sas, en el que ocupa un lugar primordial la voluntad de Dios, ni lo negamos, ni lo llamamos destino, a no ser que el término fatum lo hagamos derivar de fari, que tiene el sentido de hablar. No podemos negar que está escrito en las Sagradas Escrituras: Dios ha dicho una cosa, y dos cosas que he escuchado: "que Dios tiene el poder y el Señor tiene la gracia; que tú pagas a cada uno según sus obras" 39 . Las palabras Dios ha dicho una cosa significan algo inmutable, es decir, que ha hablado de una manera irrevocable, tal como conoce de una manera invariable todo lo que ha de venir y lo que Él mismo ha de hacer. En este sentido podríamos usar la palabra fatum (destino), como derivada de fari, si no fuera que este vocablo suele interpretarse en el otro sentido, al que no queremos ver inclinado el corazón del hombre. Pero de que para Dios esté determinado el orden de las causas, no se sigue que ya nada quede bajo nuestra libre voluntad. En efecto, nuestras voluntades mismas pertenecen a ese orden de causas, conocido de antemano por Dios en un determinado orden, puesto que la voluntad del hombre es la causa de sus actos. Por eso, quien conoce de antemano todas las causas de los acontecimientos, no puede ignorar, en esas mismas causas, nuestras voluntades, conocidas también por Él como las causas de nuestros actos.

4. El mismo enunciado concedido por Cicerón de que nada sucede sin que le preceda una causa eficiente basta para rebatirle en esta cuestión. ¿De qué le sirve afirmar que nada existe sin una causa, pero que no toda causa es fatal, puesto que hay causas fortuitas, causas naturales y causas voluntarias? Basta con haber reconocido que todo cuanto sucede, sucede por una causa anterior. Nosotros no negamos la existencia de las causas llamadas fortuitas (de donde ha tomado el nombre la fortuna). Las llamamos ocultas, y las atribuimos a la voluntad de Dios o de cualquier otro espíritu. En cuanto a las causas naturales, en modo alguno las queremos excluir de la voluntad de quien es el autor y el creador de toda naturaleza. Y referente a las causas voluntarias, o bien provienen de Dios, o de los ángeles, o de los hombres, o de alguno de los animales, si es que voluntad podemos llamar a los impulsos de los seres vivientes privados de razón, cuando, según su propia naturaleza, realizan, apetecen o rehúyen algo. Al hablar de las voluntades de los ángeles me refiero tanto a los buenos, llamados "ángeles de Dios", como a los malos, a quienes llamamos "ángeles del diablo" o también demonios. Y con los hombres lo mismo, se trate tanto de los buenos como de los malos.

Consecuencia de lo anterior es que no existen más causas eficientes de cuanto sucede que las voluntarias, es decir, procedentes de esa naturaleza que es soplo vital. Porque también llamamos soplo a este aire o viento.

${ }^{39}$ Salmos 62,12-13. 
Pero como es un cuerpo, no es el soplo vital. En realidad, el soplo vital que todo lo vivifica, que es el creador de todo cuerpo y de todo espíritu, es el mismo Dios, espíritu increado. En su voluntad reside el supremo poder, que ayuda a las voluntades buenas de los espíritus creados, juzga a las malas, a todas las ordena, y a unas les concede poderes y a otras se los niega. Del mismo modo que es el Creador de toda naturaleza, es el dispensador de todo poder, aunque no de toda voluntad. En efecto, las malas voluntades no provienen de Dios por ser contrarias a la naturaleza, la cual sí proviene de Él.

Respecto de los cuerpos, mayormente están sometidos a las voluntades, unos a las nuestras, es decir, las de todo ser viviente mortal, y preferentemente los hombres a las bestias; otros a las de los ángeles. Pero todos están sometidos principalmente a la voluntad de Dios, de quien dependen también las voluntades de todos, puesto que no tienen más poderes que los que Él les concede.

La causa de los seres que produce, pero no es producida, es Dios. Hay otras causas que también producen, obran, pero son producidas, como son todos los espíritus creados, principalmente los racionales. Pero las causas corporales, que más bien son producidas que producen ellas, no hay por qué nombrarlas entre las causas eficientes, dado que todo su poder reside en lo que la voluntad de los espíritus realiza valiéndose de ellas.

¿Cómo, pues, es posible que el orden de las causas, que está determinado en la presciencia de Dios, haga que nada dependa de nuestra voluntad, cuando en ese mismo orden de causas ocupan un lugar importante nuestras voluntades? Que se las entienda Cicerón con los que dicen que este orden de causas es fatal, o más bien le dan el nombre de destino, cosa que a nosotros nos causa repulsa, principalmente por el término, que no se ha solido entender de realidad alguna verdadera. Y cuando niega Cicerón que el orden de las causas está totalmente determinado y perfectamente conocido en la presciencia de Dios, se hace más detestable él para nosotros que para los estoicos. Porque o bien niega la existencia de Dios, cosa que ya intentó, por cierto, valiéndose de una tercera persona en su obra De Natura Deorum; o bien, si reconoce la existencia de Dios, al negarle el conocimiento del futuro no hace otra cosa que repetir aquello que dice el necio para sí: “No hay Dios”. Porque quien no conozca de antemano todos los acontecimientos futuros, ciertamente no es Dios. De ahí que nuestras voluntades en tanto pueden algo, en cuanto Dios las ha querido y previsto que pudieran. Por tanto, lo que ellas pueden, lo pueden con toda certeza, y lo que ellas van a hacer, lo han de hacer ellas mismísimas por tener previsto Él, cuya ciencia es infalible, que podrían y que lo realizarían. De ahí que, si se me ocurriera aplicarle el nombre de destino a alguna realidad, diría que el 
destino es propio de lo más inferior, y de lo superior lo es la voluntad, que tiene sometido a lo inferior bajo su poder. Preferiría decir eso antes que en virtud de ese orden de causas, llamado destino a su antojo por los estoicos, despojar de su albedrío a nuestra voluntad.

\section{CAPÍTULO X}

¿HAY ALGUNA FATALIDAD QUE TENGA DOMINADA LA VOLUNTAD HUMANA?

1. Ya no hay por qué tener miedo a aquella necesidad por temor de la cual los estoicos hicieron tan grandes esfuerzos para distinguir las causas de los seres, de tal forma que a unas las lograron sustraer de toda necesidad, y a otras las sometieron a ella. Entre las que quisieron dejar fuera de la necesidad le dieron un puesto a nuestra voluntad para evitar que no fuera libre si la dejaban bajo la necesidad.

Si hemos de llamar necesidad, con relación a nosotros, a aquella fuerza que no está en nuestra mano, sino que, aunque no queramos, ella obra lo que está en su poder, como es la necesidad de la muerte, es evidente que nuestra voluntad, causa de nuestro buen o mal vivir, no está sometida a tal necesidad. En efecto, muchas cosas hacemos que, si no quisiéramos, no las haríamos. Y en primer lugar el querer mismo: si queremos, existe; si no queremos, deja de existir: porque no vamos a querer si no queremos.

Pero si definimos la necesidad como aquello que nos hace decir: "es necesario que esto sea o suceda así”, no veo por qué la hemos de temer como si nos privase de nuestra libertad. De hecho no sometemos bajo necesidad alguna la vida y la presciencia de Dios cuando decimos que es necesario que Dios viva siempre y lo sepa todo. Tampoco queda disminuido su poder cuando afirmamos que no puede morir o equivocarse.

Cierto que no lo puede, pero si lo pudiera su poder sería, naturalmente, más reducido. Así que muy bien está que llamemos omnipotente a quien no puede morir ni equivocarse. La omnipotencia se muestra en hacer lo que se quiere, no en sufrir lo que no se quiere. Si esto tuviera lugar, jamás sería omnipotente. De ahí que algunas cosas no le son posibles, precisamente por ser omnipotente.

Esto mismo sucede al decir que es necesario, cuando queremos, querer con libre albedrío. Decimos una gran verdad, y no por ello sometemos al mismo libre albedrío a la necesidad que priva de la libertad. Ahí están nuestras voluntades; son ellas mismas quienes hacen lo que hacemos queriendo. Y no lo harían si no quisiéramos. Pero cuando alguien soporta algo a pesar suyo, por voluntad de otros hombres, también en ese caso se trata de 
un efecto de la voluntad, que, aunque no suya, sí es una voluntad humana. Sin embargo, el poder en este caso es de Dios. (Porque si se tratase solamente de una voluntad que no pudiera realizar lo que quería, estaría impedida por otra voluntad más poderosa; e incluso en este caso la voluntad no sería otra cosa más que voluntad, y no de otro, sino de quien estuviese queriendo, aunque su deseo no se pudiera cumplir.) Así, pues, todo lo que el hombre sufre contra su voluntad no debe atribuírselo a la voluntad de los hombres o de los ángeles o de cualquier otro espíritu creado, sino a la de aquel que concede un determinado poder a quienes son capaces de querer.

2. No porque Dios hubiera previsto lo que iba a querer nuestra voluntad, va a dejar ésta de ser libre. Quien esto previó, previó algo real. Ahora bien, si quien previó el contenido futuro de nuestra voluntad tuvo conocimiento no de la nada, sino de algo real, se sigue que, según esa misma presciencia, algo depende de nuestra voluntad. Luego nada nos obliga a despojar a la voluntad de su albedrío para mantener la presciencia de Dios, ni a negar que Dios desconoce el futuro (sería una afirmación sacrílega) con el fin de salvar el libre albedrío humano. Por el contrario, aceptemos una y otra verdad y ambas las confesamos leal y sinceramente: la una para nuestra rectitud en la fe, y la otra para nuestra rectitud en la conducta. Mal vive quien de Dios no cree rectamente. Lejos de nosotros el que, para afirmar nuestra libertad, neguemos la presciencia de aquel por cuyo favor somos o seremos libres.

Así, pues, no son inútiles las leyes, ni las reprensiones, ni las exhortaciones, ni las alabanzas, ni los vituperios. Todo esto estaba previsto por Él, y tienen todo el valor que Él previó que tendrían. Incluso las súplicas tienen valor para alcanzar aquello que Él había previsto conceder a quienes lo pidiesen. Y justamente se dan premios a las buenas acciones y se establecen castigos para los delitos. Y no peca el hombre por haber previsto Dios que pecaría; es más, queda fuera de toda duda que cuando peca es él quien peca, porque Aquel cuya presciencia es infalible, conocía ya que no sería el destino, ni la fortuna, ni otra realidad cualquiera, sino el hombre mismo quien iba a pecar. Y si él no quiere, por supuesto que no peca. Pero si no hubiera querido pecar, también esto lo habría previsto Dios.

\section{CAPÍTULO XI}

LA PROVIDENCIA UNIVERSAL DE DIOS, CUYAS LEYES LO ABARCAN TODO

El Dios supremo y verdadero, con su Palabra y el Espíritu Santo, tres que son uno, Dios único todopoderoso, creador y formador de toda alma y 
de todo cuerpo, por cuya participación son felices quienes son realmente, no engañosamente felices; que ha formado al hombre como animal racional, compuesto de alma y cuerpo; que, al pecar el hombre, ni lo dejó impune ni lo abandonó sin misericordia; este Dios, que ha dotado tanto a buenos como a malos del ser, común con las piedras, de la vida vegetativa con las plantas, la vida sensitiva con las animales, la vida intelectual, común únicamente con los ángeles; de quien procede toda regla, toda forma, todo orden; en quien se funda la medida, el número, el peso; a quien todo ser le debe su naturaleza, su especie, su valor, cualquiera que éste sea; de quien provienen los gérmenes de las formas, las formas de los gérmenes y la evolución de gérmenes y de formas; que dio a toda carne su origen, su hermosura, su salud, su fecundidad expansiva, la distribución de sus miembros, su saludable armonía; ese Dios que ha dotado al alma irracional de memoria, de sensación, de instintos, y a la racional, además, de espíritu, de inteligencia, de voluntad; que se preocupó de no dejar abandonados no ya al cielo y a la tierra, o únicamente a los ángeles y hombres, sino ni siquiera las vísceras de la más insignificante y despreciable alimaña, o una simple pluma de ave, ni a una florecilla del campo, ni una hoja de árbol, sin que tuviera una proporción armoniosa en sus partes, y una paz en cierto modo: es totalmente inconcebible que este Dios hubiera pretendido dejar a los reinos humanos, a sus períodos de dominación y de sometimiento fuera de las leyes de su providencia.

\section{CAPÍTULO XII}

Conducta de los ANTIGUOS ROMANOS, QUE LES MERECIÓ DEL Dios VERDADERO, AUNQUE NO ADORADO POR ELLOS, EL CRECIMIENTO DE SU PODERÍO

1. Veamos ahora cuáles fueron las costumbres de los romanos y cuál ha sido la causa por la que les ha prestado su ayuda para el engrandecimiento de su poder el Dios verdadero, en cuyas manos están también los reinos de la tierra. Con vistas a una más detenida exposición sobre este punto, hemos escrito el libro precedente, donde dejamos en claro que en esta materia el poder de los dioses, a quienes daban un culto ridículo, es nulo. Los precedentes capítulos de este libro que acabamos de tratar tienen por objeto acabar con la cuestión del destino, no sea que alguien, ya persuadido de que la propagación y el mantenimiento del Imperio Romano no se debe al culto de tales dioses, se lo vaya ahora a atribuir a no sé qué destino fatal, en lugar de atribuírselo a la voluntad del Dios supremo. 
Aquellos viejos romanos de los primeros tiempos, a juzgar por lo que la historia nos transmite y nos encomia de ellos, no obstante seguir el mismo camino que los demás países — con la única excepción del pueblo hebreo_- dando culto a los dioses falsos, inmolando víctimas no a Dios, sino a los demonios; sin embargo, “eran ávidos de alabanza, desprendidos del dinero; su ambición era una gloria elevada y una fortuna adquirida honradamente" ${ }^{40}$. Esta fue su pasión más ardiente: ella era la razón de su vivir, por ella no dudaron en entregarse a la muerte; esta sola pasión por la gloria llegó a ser tan poderosa que ahogó a todas las demás. Y como la esclavitud les parecía una ignominia, mientras que el ser dueños y señores, una gloria; todo su empeño fue desear que su patria fuera primeramente libre, y luego la dueña del mundo.

Aquí radica el que, reacios a toda dominación monárquica, “crearon magistraturas anuales, repartiendo el poder supremo entre dos a quienes llamaron cónsules, derivado de consulere (deliberar), en lugar de llamarles reyes o señores (dueños), que se relacionan con los términos regnare (reinar) y dominari (imponer su dominio)"41. Aunque mejor parecería hacer derivar reyes (reges) del vocablo regir (regere), así como reino (regnum) del vocablo reyes (reges). Pero les pareció que el fasto regio no era propio de la vida disciplinada de un guía, ni de la benevolencia de un mentor, sino de la soberbia de un tirano.

El resultado fue que tras la expulsión del rey Tarquinio ${ }^{42}$ y la institución de los cónsules, se siguió un período del que habla el mismo Salustio en términos laudatorios para los romanos, así: "Parece increíble lo rápidamente que Roma creció, una vez conseguida su libertad; tal fue su pasión por la gloria”43. Esta avidez por la alabanza y la pasión por la gloria fue quien realizó tantas maravillas, dignas, por cierto, de alabanzas y de gloria, según la estimación de los humanos.

2. El mismo Salustio elogia a dos grandes hombres, ilustres en su época: Marco Catón y Cayo César ${ }^{44}$. Dice que aquella República careció durante mucho tiempo de hombres de gran talla, pero que en su época hubo estos dos de excelentes cualidades, aunque de opuesta forma. Elogia a

40 Salustio, Conjuración de Catilina, 7,6 (2000, p. 9).

41 Ibid., 6,7 (2000, pp. 8-9); Cicerón, Sobre la República, 2,31 (1991, pp. 113114).

42 Se trata del último rey de Roma antes de la instauración de la república. Se estima que su reinado se extendió entre el 534 y el 510 a.C.

43 Salustio, Conjuración de Catilina, 7,3 (2000, p. 9).

44 Ibid., 53-54 (2000, pp. 56-57). Marco Porcio Catón (94-46 a.C.), llamado de Útica, filósofo estoico conocido por su rectitud moral. Gayo César, más conocido como Julio César, se convierte en dictador de Roma en el 48 a.C. 
César por su deseo de una vasta dominación, un poderoso ejército y una guerra nueva, donde pudiera brillar su talento militar. Lo que sucedía era que en las intenciones de estos hombres, colosos por su valor, estaba Belona $^{45}$ azuzando a las desdichadas naciones a la guerra, y excitándolas con su sanguinario látigo ${ }^{46}$, a fin de dar una ocasión de que brillase su valor. Estos eran los resultados de aquella avidez de alabanza y de su pasión por la gloria. Todas estas grandezas fueron la consecuencia de aquel amor a la libertad, primero, y después al dominio, y de aquel ansia de alabanza y de gloria.

De ambas cosas les ha dejado testimonio su insigne poeta. Dice así: "Ordenaba Porsena que se acogiera también al desterrado Tarquinio. Él estaba atenazando la ciudad con un duro asedio. Pero los descendientes de Eneas se lanzaban a las armas por defender su libertad"47. Para ellos, en este tiempo, la grandeza consistía en vivir libres o en morir valerosamente. Pero, cuando ya disfrutaron de libertad, les invadió una tal pasión de gloria, que la sola libertad les pareció poco si no iban en busca del señorío mundial. Significaba mucho para ellos lo que el mismo poeta dice, poniéndolo en boca de Júpiter: "Mas aún, la áspera Juno, que ahora tiene agobiados con su terror el mar, la tierra y el cielo, mejorará de propósito, y conmigo se pondrá de parte de los romanos, ese pueblo togado, dueño del mundo. Tal es mi deseo. Llegará con el correr de los años un tiempo en que la casa de Asáraco someterá a servidumbre a Ptía y a la ilustre Micenas, y será dueña de la vencida Argos" ${ }^{\prime 4}$.

Realmente lo que Virgilio pone en boca de Júpiter, pronosticando el futuro, para él era una evocación de acontecimientos ya realizados, y que los tenía ante sus ojos. Pero yo lo he querido recordar para evidenciar cómo los romanos, después de su libertad, han puesto por las nubes su espíritu dominador, hasta contarlo entre sus grandes alabanzas. Esta es la razón que mueve a Virgilio, más adelante, a anteponer a las artes de los demás países el arte específico romano: regir, dominar, subyugar y conquistar por las armas a los pueblos. Dice así: "Otros habrá que con habilidad forjarán el

\footnotetext{
45 Diosa romana de la guerra.

46 Virgilio, Eneida, VIII, 703 (2000, p. 254).

47 Ibid., VIII, 646-648 (2000, p. 252). La tradición consideraba a Porsena un rey etrusco que asistió a Tarquino. Véase Tito Livio, Historia de Roma desde su Fundación, II, 9 (1990a, pp. 282-283).

48 Virgilio, Eneida, I, 279-283 (2000, p. 18). Esta referencia se hace en el contexto de la legendaria ascendencia troyana de los romanos que relata Virgilio en la Eneida. Argos, Micenas y Ptía eran ciudades griegas que fueron conquistadas por Roma; Asáraco, rey de Troya, fue el bisabuelo de Eneas — es decir, "la casa de Asáraco" son los romanos. Juno, esposa de Júpiter el rey de los dioses romanos, favoreció a los griegos en la Guerra de Troya, despechada como estaba por el famoso juicio de Paris.
} 
bronce hasta darle aliento, así lo creo, y que lograrán sacar del mármol rostros vivientes; sabrán defender las causas con mayor elocuencia; trazarán con el compás los caminos del cielo, y hablaran del nacimiento de los astros. Pero tú, romano, pon tu atención en gobernar los pueblos con tu dominio. Estas serán tus artes: imponer las normas de la paz, perdonar a los vencidos y derrocar a los soberbios”49.

3. Estas artes las practicaban los romanos con tanta mayor habilidad cuanto menos se entregaban a los placeres, y menos se daban al envilecimiento del espíritu y del cuerpo por el ansia de adquirir y aumentar su riqueza, echando a perder por ella sus costumbres, robando a los pobres ciudadanos y derrochando con los viles histriones. Pero cuando Salustio escribía esto y lo cantaba Virgilio, los romanos superaban y doblaban a sus antepasados, pero en la corrupción de costumbres; ya no andaban en busca de honores y gloria con aquellas artes, sino con astucias tramposas. Por ello dice Salustio: "En un principio la ambición movía más el corazón humano que la avaricia. Pero este vicio estaba muy cerca de ser virtud. Porque lo mismo el bueno que el indolente desean la gloria, el honor, el poder. Pero aquél lo hace por medios lícitos, pero éste, al carecer de honrosas habilidades, lo intenta con astucias engañosas"

Estas son las artes honrosas: a través de la virtud (y no precisamente a través de una astuta ambición) llegar al honor, a la gloria y al poder. Por igual, honrados e indolentes los desean para sí; pero aquéllos lo intentan por caminos legales. El camino es la virtud, por el que uno se esfuerza en conseguir algo: la gloria, el honor, el poder.

Testimonio de que los romanos llevaban esto muy dentro son los dos templos, levantados muy cerca uno del otro a la Virtud y al Honor, tomando por dioses lo que no son sino un simple don de Dios. De esto podemos deducir cuál era el fin de la virtud para los hombres de bien, y a dónde la orientaban: al honor. Porque los malos ni siquiera la tenían, aun cuando ambicionaban el honor; pero lo hacían valiéndose de malas artimañas, es decir, con astucias engañosas.

4. Mejor parado que César queda Catón. Dice de él Salustio: "Cuanto menos ambicionaba la gloria, más gloria le venía"51. De hecho la gloria, por la que todos se abrasaban en ambición de conseguirla, es la buena opinión que los hombres se forman de otros hombres. Por eso mejor es la virtud, ya que no depende del testimonio humano, sino que reside en la propia con-

\footnotetext{
${ }^{49}$ Ibid., VI, 847-843 (2000, p. 191).

50 Salustio, Conjuración de Catilina, 11, 1-3 (2000, pp. 11-12).

${ }^{51}$ Ibid., 54, 6 (2000, p. 57).
} 
ciencia. Así, dice el Apóstoll ${ }^{52}$ : Mi gloria el testimonio de mi conciencia ${ }^{53}$. Y en otro pasaje: Cada cual examine su propia actuación y tendrá entonces motivo de satisfacción refiriéndose sólo a sí mismo, no al compañe$r^{54}$. No es, por consiguiente, la virtud quien debe seguir a la gloria, al honor y al poder, deseados por los hombres honrados e intentados por buenos caminos; son ellos los que deben seguir a la virtud. No hay verdadera virtud si no se tiende a aquel fin en el que reside el bien del hombre, mejor que el cual no hay otro. De ahí que los honores que Catón solicitaba, no los debió solicitar. Era la ciudad quien por su virtud debía habérselos concedido sin que él los solicitase.

5. Pero como en aquellos días había dos romanos eminentes en virtud, César y Catón, la de Catón parece acercarse mucho más a la verdad que la de César. Veamos, pues, cómo era por entonces Roma, y cómo lo había sido antes, según el mismo parecer de Catón: "No creáis — dice— que nuestros mayores han hecho grande aquel estado pequeño por las armas. Si fuera así, mucho más hermosa sería hoy nuestra República. Mayor abundancia de aliados, de ciudadanos, aparte de armas y caballería, tenemos nosotros que tuvieron nuestros abuelos. Pero fueron otros los recursos que a ellos los hicieron grandes, y que a nosotros nos faltan en absoluto: dedicación al trabajo dentro de la patria y fuera de ella, una dominación justa, espíritu de libertad en las decisiones, sin las trabas del crimen ni de las pasiones. En lugar de todo esto, nosotros tenemos el lujo y la codicia; oficialmente reina la miseria, y en privado la opulencia; alabamos la riqueza, pero nos entregamos a la indolencia; no somos capaces de distinguir el honrado del perverso; todas las recompensas de la virtud las acapara la ambición. Y no tiene nada de extraño cuando cada uno de vosotros toma las decisiones por su cuenta, cuando en casa os entregáis a los placeres, y aquí, en la política, os rebajáis hasta la esclavitud por el dinero o el favor de los poderosos. Así sucede que todos arremeten contra el Estado como si fuera una hacienda abandonada" 55 .

6. Quien escuche estas palabras de Catón —o de Salustio—, laudatorias de los viejos romanos, pensará que todos, o la mayoría de ellos, eran acreedores de tales elogios. No es así. De otro modo, no sería cierto lo que él mismo escribe y que he citado en el libro II de esta obra ${ }^{56}$. Dice que las

\footnotetext{
52 San Pablo.

532 Corintios, 1,12 .

${ }^{54}$ Gálatas, 6,4.

55 Salustio, Conjuración de Catilina, 52, 19-24 (2000, pp. 53-54).

${ }^{56}$ Salustio, Fragmentos de las Historias, 11 (2000, p. 195). El pasaje es citado literalmente por Agustín en el libro II, 18, no incluido en esta selección.
} 
injusticias de los más poderosos dieron lugar en la política interna a una ruptura entre el pueblo y los patricios, junto con otras escisiones, ya desde el principio. La duración del período en que reinó un derecho justo y bien aplicado, después de expulsada la monarquía, no duró más allá del miedo a Tarquinio, hasta el fin de la pesada guerra que por su causa estaban librando en Etruria. Pero después los patricios trataban al pueblo como si fueran esclavos, los castigaban de un modo tiránico, los expulsaron de sus tierras y acapararon ellos solos, con exclusión de los demás partidos, toda la acción política.

El final de todas estas discordias, unos con afanes de dominio y los otros rechazando el yugo, sólo llegó con la segunda guerra púnica. Una vez más, fue el miedo de una grave catástrofe lo que empezó a mover los ánimos con urgencia, apagando la inquietud de tales perturbaciones con una preocupación aún más grave. La consecuencia fue la concordia ciudadana. Pero unos cuantos, honrados según sus criterios, tenían en su mano la administración de grandes fuerzas. Una vez atenuadas y pasadas estas calamidades, la República fue creciendo gracias a la providencia de ese pequeño grupo de honrados, como atestigua el mismo historiador.

Es Salustio quien de oídas unas veces, y otras en sus lecturas, tuvo noticia de las muchas hazañas que el pueblo romano realizó, en paz y en guerra, por tierra y por mar. Y se interesó por saber qué fue lo que sostuvo tamaña empresa. Sabía que en muchas ocasiones se habían enfrentado un puñado de romanos a enormes legiones de enemigos; tenía noticia de que se habían librado guerras con escasos recursos contra opulentos reyes. Y afirmó que después de muchas reflexiones había llegado a la convicción de que todo esto se debía a la egregia virtud de unos cuantos ciudadanos, logrando que la pobreza venciera a la opulencia, y un grupo reducido, a masas enteras. "Pero una vez que el lujo y la indolencia — prosigue Salustio- corrompieron a los ciudadanos, de nuevo la República, con su magnitud, sustentaba los vicios de generales y magistrados" ${ }^{27}$.

También Catón elogia la virtud de unos cuantos que aspiraban a la gloria, al honor y al poder por caminos legítimos, es decir, por la virtud misma. De ahí que - como el mismo Catón nos recuerda - dentro de la patria había empeño por el trabajo, de forma que el erario público era opulento, y modestas las fortunas privadas. Luego, el vicio, tras corromper las virtudes, volvió las cosas al revés: la hacienda pública era ruinosa, y en privado se vivía la opulencia ${ }^{58}$.

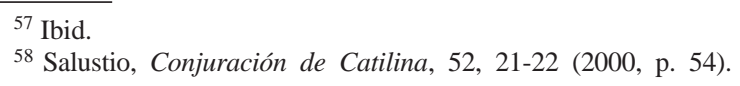




\section{CAPÍTULO XIII}

El AMOR A la AlabanZa ES UN VICIO. PERO AL SERVIR DE FRENO A OTROS VICIOS MAYORES, SE LE CONSIDERA UNA VIRTUD

Los imperios de Oriente brillaron durante largos períodos. Por eso quiso Dios que hubiera también uno en Occidente, posterior en el tiempo, pero más célebre que ellos por la vasta extensión de sus dominios. Fue una concesión que hizo Dios a estos hombres con el fin primordial de atajar los graves males que padecían muchas naciones. Ellos, aunque iban en busca del honor, la gloria y la alabanza, miraban por su patria. Para ella buscaban esta misma gloria, y no dudaron en anteponer la salvación de la patria a su propia vida. Así, este único vicio suyo, el amor a la alabanza, sirvió de contención a la codicia del dinero y a otros muchos vicios.

Juicio de una gran cordura es llamar vicio al amor por la alabanza. Hasta el poeta Horacio ${ }^{59}$ lo llega a percibir en sus versos. Dice así: “¿Te sientes hinchado por el deseo de la alabanza? Hay infalibles remedios en un librito: si lo lees tres veces con atención, te sentirás aliviado” ${ }^{\prime 6}$. Y canta también en uno de sus poemas líricos para reprimir la pasión del dominio: “Tu reino será mucho más vasto si logras dominar tu espíritu ambicioso que si consigues acumular dominios desde la remota Cádiz hasta Libia, y si las dos Cartagos se te rinden”61.

Sin embargo, quienes no refrenan sus pasiones más torpes, invocando el Espíritu con fe transida de piedad, y enamorándose de la belleza inteligible, al menos se vuelven mejores por el deseo de la alabanza y gloria humanas. No digo precisamente que se hagan santos, sino menos viles. Ya Cicerón, en su obra la República, no pudo pasar por alto este pensamiento. Habla allí de la instrucción de un jefe de Estado, y dice cómo se le debe alimentar de gloria, y recordarle cómo sus antepasados han realizado muchas proezas admirables y gloriosas por la pasión de la gloria ${ }^{62}$.

No solamente no ponían los romanos resistencia a tal vicio. Al contrario, pensaban que había que avivarlo, encenderlo, puesto que lo tenían como útil para la patria. Ni siquiera en sus tratados filosóficos Marco Tulio ${ }^{63}$ se aparta de esta peste: lo afirma más claro que la luz del día. Y al hablar de los estudios que es preciso cursar para entrar en posesión del verdadero bien, y no del viento de la humana alabanza, introdujo este dicho general y

\footnotetext{
${ }^{59}$ Horacio (65-8 a.C.), poeta romano.

${ }^{60}$ Horacio, Epístolas 1, 1, 36-37.

${ }^{61}$ Horacio, Oda 2, 2, 9-12.

62 Cicerón, Sobre la República, 5, 7, 9 (1991, p. 155).

${ }^{63}$ Cicerón.
} 
universal: "Es el honor alimento de las artes, Los hombres se inflaman en ardor del estudio buscando la gloria y yacen siempre por tierra las ciencias que están en descrédito" ${ }^{\circ 4}$.

\section{CAPÍTULO XIV}

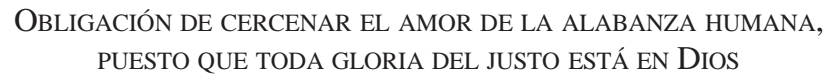

Es preferible, sin duda alguna, resistir a esta pasión que ceder a ella. Porque tanto más se asemeja uno a Dios cuanto está más limpio de esta inmundicia. En la presente vida, aunque no se llega a arrancar su raíz del corazón, porque no deja de salir al paso, tentando incluso a los espíritus muy adelantados, al menos que la pasión por la gloria quede vencida por el amor a la justicia. Si en algún lugar "yacen por tierra los estudios que están en descrédito", si éstos son buenos, si son justos, que se cubra de vergüenza el amor a la gloria y deje paso al amor a la verdad. Llega a ser tan contrario a la fe de un hombre religioso este vicio, cuando la pasión por la gloria supera de corazón al temor o al amor de Dios, que el Señor dejó dicho: ¿Cómo os va a ser posible creer a vosotros, que os dedicáis al intercambio de honores, y no buscáis el honor que viene del único Dios? ${ }^{65} \mathrm{Y}$ a propósito de algunos que habían creído en Él, y se avergonzaban de confesarlo en público, dice el evangelista: Preferían el honor que dan los hombres al que da $\operatorname{Dios}^{66}$.

No fue este el proceder de los apóstoles. Ellos predicaban el nombre de Cristo no sólo en lugares donde estaba en descrédito (volviendo a las palabras de Cicerón: "Yacen siempre por tierra las ciencias que están en descrédito"), sino incluso lo predicaban donde era objeto del mayor odio. Eran fieles a las recomendaciones del Maestro bueno y Médico de las almas: Si uno me niega ante los hombres, yo lo negaré a él ante mi Padre que está en el cielo y ante los ángeles de Dios ${ }^{67}$. Entre maldiciones y oprobios, entre las más graves persecuciones y tormentos crueles, todo este bramido inmenso de la oposición humana no fue capaz de arredrarlos de predicar la salvación a la humanidad. Realizaron obras divinas, hablaron palabras divinas, vivieron una vida divina; derrocaron, en cierto modo, corazones empedernidos; introdujeron en el mundo la paz fundada en la justicia; consiguieron para la Iglesia de Cristo una gloria inmensa; no por eso descansaron en ella como en el fin conseguido de su propia virtud; al con-

${ }^{64}$ Cicerón, Disputaciones Tusculanas, 1,2,4 (2005).

65 Juan 5,44.

66 Juan 12,43 .

${ }^{67}$ Mateo 10, 33; Lucas 12, 9. 
trario, la referían siempre a la gloria de Dios, por cuya gracia eran lo que eran. Y con este mismo fuego procuraban inflamar a quienes guiaban en el amor de aquel Dios que les había de transformar como a ellos.

Para evitar que la razón de su virtud fuera la gloria humana, ya su Maestro les había adoctrinado con estas palabras: Cuidado con hacer vuestras obras de piedad delante de la gente para llamar la atención; si no, os quedáis sin paga de vuestro Padre del cielo ${ }^{68}$. Pero para que no interpretasen exageradamente tal recomendación, y por miedo a agradar a los hombres ocultasen su bondad, con perjuicio del fruto apostólico, les aclaró el motivo por el que debían dejarse ver: Brillen también - les dijovuestras obras ante los hombres; que vean el bien que hacéis y glorifiquen $a$ vuestro Padre del cielo ${ }^{69}$. Así, pues, no para llamar la atención, es decir, con la intención de que se fijen en vosotros, que nada sois por vosotros mismos, sino para que glorifiquen a vuestro Padre del cielo, al cual, si se vuelven, se harán semejantes a vosotros.

A los apóstoles les siguieron los mártires, que superaron a los Escévolas, a los Curcios y a los Decios ${ }^{70}$, no por infligirse a sí mismos torturas, sino por soportar las que se les infligían con una fortaleza más auténtica, con espíritu religioso más verdadero y por ser su número incontable. Pero como éstos eran ciudadanos de la ciudad terrena y se habían propuesto como fin de todas sus obligaciones el mantenerla a salvo y verla reinando no en el cielo, sino en la tierra, no por toda una vida eterna, sino en el fluir de unos que mueren, sucedidos por otros que luego morirán, ¿qué otros valores iban a amar, sino la gloria por la que pretendían sobrevivir como en boca de sus admiradores, aun después de la muerte?

\section{CAPITULO XV \\ GALARDÓN TEMPORAL CON EL QUE DiOS RECOMPENSÓ \\ LAS SANAS COSTUMBRES DE LOS ROMANOS}

A estos ciudadanos de la ciudad terrestre Dios no les había de conceder la vida eterna en su ciudad celestial, y en compañía de sus santos ángeles. El camino para llegar hasta allá es el de la verdadera actitud religio-

\footnotetext{
68 Mateo 6,1.

69 Mateo 5,16.

${ }^{70}$ Héroes romanos que en nombre de la gloria se autoinfligieron daño físico. Mucio Escévola se quemó la mano derecha ("Escévola" significa "el Zurdo"; véase Tito Livio, Historia de Roma..., II, 12 (1990a, pp. 287-290)). Marcos Curcio se lanzó a un barranco ya que un oráculo indicaba que sólo si la mayor fortaleza de Roma se tiraba por el barranco, éste se cerraría (Tito Livio, Historia de Roma..., VII, 6 (1990b, pp. 280285)). Los Decios, padre e hijo, se entregaron a una muerte segura en sendas batallas (Tito Livio, Historia de Roma..., VIII, 9 (1990c, 33-37)).
} 
sa, que sólo se manifiesta cuando se tributa al único Dios verdadero el servicio cultural, llamado latría por los griegos. Si este Dios no les concediese ni siquiera la terrena gloria de lograr un magnífico imperio, no les daría la paga a sus buenas artes, es decir, a sus virtudes, mediante las cuales se esforzaban por conseguir una gloria tan brillante.

Precisamente de aquellos que parecen realizar algún bien con vistas a la gloria humana, dice también el Señor: Ya han cobrado su paga, os lo aseguro $^{71}$. De hecho, estos hombres llegaron a desprenderse de su fortuna por la colectividad, es decir, por el Estado y su tesoro público; frenaron su codicia, miraron sin interés alguno por el bien de la patria; estaban inmunes de todo delito y de todo vicio castigados por sus leyes. Valiéndose de todas estas artes como de un camino legítimo, pusieron su empeño en lograr honores, poder, gloria; en casi todos los países han logrado ser honrados; gran número de ellos han estado sometidos a su poder, bajo la legislación; en casi todos ellos, en fin, su gloria es proclamada hoy en los escritos de los historiadores. No tendrán por qué quejarse de la justicia del supremo y verdadero Dios: Ya han cobrado su paga.

\section{CAPÍTULO XVI}

\section{RECOMPENSA DE LOS SANTOS MORADORES DE LA CIUDAD ETERNA, A QUIENES SON} DE UTILIDAD LOS EJEMPLOS DE LAS VIRTUDES ROMANAS

Pero muy distinta es, incluso aquí abajo, la paga de los santos, que tienen que soportar oprobios por la Ciudad de Dios, odiosa para los enamorados de este mundo. Se trata de una ciudad eterna: allí no nace nadie, porque nadie muere; allí reina la verdadera y plena felicidad (que no es diosa, sino un don de Dios); de ella, como prenda de su posesión, hemos recibido la fe para el tiempo en que, peregrinos, suspiramos por su hermosura; allí no sale el sol sobre malos y buenos: sólo hay un sol, el sol de justicia, que protege a los buenos; allí no habrá que hacer grandes esfuerzos para enriquecer el erario público a expensas de las fortunas privadas: la verdad es su común tesoro.

No ha sido, pues, ensanchado el poderío romano, hasta alcanzar la humana gloria, únicamente para recompensar adecuadamente a estos hombres; lo ha sido también para que los ciudadanos de aquella ciudad eterna, mientras son peregrinos de aquí abajo, se fijen con atención y cordura en sus ejemplos. Verán cómo debe ser amada la patria celeste por la vida eterna, cuando tanto amaron la terrena sus ciudadanos por la gloria humana.

${ }^{71}$ Mateo 6,2. 


\section{CAPÍTULO XVII \\ LAS GUERRAS DE ROMA: FRUTOS QUE LE REPORTARON \\ Y UTILIDAD PARA LOS VENCIDOS}

1. Con respecto a la presente vida de los mortales, que se desliza en un puñado de días y luego se termina, ¿qué interés tiene para el hombre vivir bajo un dominio político u otro, con tal que los gobernantes no nos obliguen a cometer impiedades o injusticias? ¿Qué daño causaron los romanos a los países que sometieron e impusieron sus leyes, si no es el que lo llevaron a cabo mediante encarnizadas guerras? Si esto lo hubiesen conseguido en mutua concordia, los resultados habrían sido mejores; sólo que no habría gloria del triunfador. De hecho los romanos vivían bajo las mismas leyes que imponían a los demás.

Si todo esto se hubiera conseguido sin la intervención de Marte $^{72}$, ni Belona, ni, por consiguiente, hubiera tenido lugar en su actuación la Victoria $^{73}$, sin haber vencedores por no haber habido luchadores, ¿¿no estarían en una misma situación Roma y los demás países? Sobre todo si a continuación se hacía lo que andando el tiempo se hizo con sumo agrado de todos y en un rasgo de gran humanidad: que todos los que formaban parte del Imperio Romano fueran miembros de la comunidad ciudadana, convirtiéndose en ciudadanos romanos. Así, pasaba a ser de todos lo que antes pertenecía a unos pocos. Sólo que aquella plebe que no tenía campos propios debía vivir a expensas de la hacienda pública. A esta manutención contribuirían mucho más gustosamente los pueblos pacíficamente llegados a un acuerdo, y a través de buenos administradores públicos, que si después de vencidos tuvieran que arrancárselo por la fuerza.

2. Yo no veo, en realidad, qué importancia puede tener para la seguridad y la moralidad ciudadana lo que aseguramos ser méritos de los hombres: el que unos sean vencedores y los otros vencidos, a no ser ese orgullo absolutamente vacío de la gloria humana, en el cual ya recibieron su paga quienes, ardiendo en una inmensa pasión por alcanzarla, inflamaron a otros en la ferocidad de las guerras. ¿'No cobran los impuestos de sus tierras? ¿Tienen acaso el privilegio de adquirir unos conocimientos que los demás no tienen? ¿No son muchos de ellos senadores de otros países, sin que conozcan a Roma ni de vista siquiera? Si quitamos la hinchazón del orgullo, ¿qué son todos los hombres más que hombres? Pero, aunque la

${ }^{72}$ Dios romano de la guerra, a veces caracterizado como esposo de la diosa de la guerra, Belona.

${ }^{73}$ Diosa romana de la victoria, especialmente bélica. Equivalente a la diosa griega Nike. 
perversidad mundana admitiese que fueran más honrados los mejores, ni aún así el honor humano debería ser tenido en gran estima: es humo que se lleva el viento.

Pero saquemos provecho hasta de estas realidades que nos concede el Señor nuestro Dios. Fijémonos: ¡cuántas grandezas despreciadas! ¡Cuántas pruebas soportadas! ¡Cuántas ambiciones ahogadas! Y todo por conseguir la gloria humana, estos hombres que han merecido recibirla como paga de tan altas virtudes. ¡Que nos sirva también a nosotros para reprimir nuestro orgullo! y puesto que entre aquella ciudad, en la que se nos ha prometido reinar, y la de aquí abajo, hay tanta distancia cuanta del cielo a la tierra; de la vida eterna, a una alegría temporal; de una sólida gloria, a huecas alabanzas; de la compañía de los ángeles, a la de los mortales; de la luz del sol y de la luna, a la luz de quien es autor del sol y de la luna, no crean nunca los ciudadanos de una tan magnífica patria haber realizado algo grande, cuando por su conquista practiquen alguna obra buena o tengan que soportar algún dolor.

Ahí tenemos a los romanos, que por su patria terrena, ya posesión suya, llevaron a cabo tantas proezas, soportaron tantas incomodidades. $\mathrm{Y}$ esto mucho más cuanto que el perdón de los pecados, que congrega a los ciudadanos para la celestial Patria, tiene un algo de parecido, como si hubiera tenido una misteriosa sombra en aquel asilo fundado por Rómulo ${ }^{74}$, a donde la impunidad de toda clase de crímenes reunió a una multitud, gracias a la cual se fundó la célebre ciudad.

\section{CAPÍTULO XVIII}

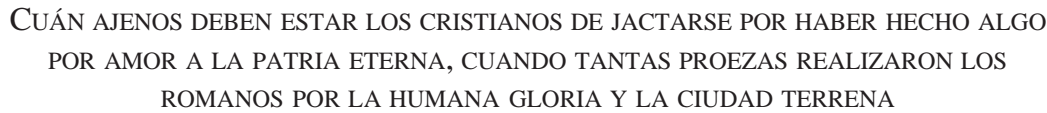

1. ¿Qué tiene de extraordinario el desdeñar por aquella celestial y eterna Patria todas las seducciones de este siglo, por muy encantadoras que sean, cuando por esta patria, terrena y temporal, un Bruto pudo armarse de valor hasta ejecutar a sus propios hijos, obligación que nunca impondrá aquella Patria? ${ }^{75}$ Por supuesto, mucho más costoso es dar muerte a los hijos

${ }^{74}$ Fundador legendario de Roma, supuestamente hijo de Marte junto a su hermano gemelo Remo. Rómulo asesina a Remo para convertirse en único rey de Roma. Tito Livio, Historia de Roma..., I, 4-6 (1990a, pp. 171-176).

75 Bruto fue líder de la revuelta que destituye a los Tarquinos, los últimos reyes romanos, y uno de los dos primeros cónsules de la república. Sus hijos conspiraron para restituir la monarquía y Bruto los condenó a muerte. Tito Livio, Historia de Roma..., II, 2-5 (1990a, pp. 270-276). 
que las obligaciones que esta Patria nos impone: los bienes que teníamos intención de reunir para nuestros hijos, darlos a los pobres o perderlos si se presentase una prueba que nos obligase a ello en nombre de la fe y de la justicia. No nos hacen felices ni a nosotros ni a nuestros hijos las riquezas terrenas: las hemos de perder en vida, o, una vez muertos, se las llevarán quienes no sabemos, o quizás, quizás, quienes no queremos. A nosotros nos hace felices Dios, auténtica riqueza del alma. Pero con respecto a Bruto, el mismo poeta que lo ensalza da testimonio de su desgracia por haber degollado a sus hijos. He aquí sus palabras: "Este padre, enarbolando la bandera sublime de la libertad, condena al suplicio a sus propios hijos, que estaban urdiendo nuevas guerras. ¡Desdichado!, piense lo que piense de estos hechos la posteridad." No obstante, el verso que sigue proporciona un consuelo a su infelicidad: "Ha quedado triunfante el amor a la patria y la infinita pasión por la gloria”76.

He aquí los dos resortes que han impulsado a los romanos a realizar sus admirables proezas: la libertad y la pasión por la gloria humana. Si, pues, por la libertad de unos hombres que han de morir, y por el deseo de una gloria que se reclama a los mortales, un padre ha llegado a ejecutar a sus hijos, ¿qué tiene de extraordinario si por la verdadera libertad, que nos rompe las cadenas del pecado y de la muerte y del dominio del diablo, no buscando humanas alabanzas, sino por el amor de unos hombres que hay que librar no de la tiranía de un Tarquinio, sino de los demonios y del príncipe de los demonios; qué tiene de extraordinario, digo, si estamos dispuestos no ya a matar a nuestros hijos, sino a contar a los pobres de Cristo en el número de nuestros hijos?

2. Hubo otro noble romano, llamado Torcuato, que también ejecutó a su hijo por haber desencadenado una lucha, y no precisamente contra su patria, sino a su favor, pero en contra de sus órdenes, es decir, en contra de la orden del general, su padre ${ }^{77}$. Provocado por el enemigo, luchó con ardor juvenil y quedó vencedor. No obstante, su padre lo ajustició: no quiso consentir que el ejemplo de una orden no acatada fuese peor que el bien reportado por la gloria de un enemigo abatido. A la vista de estos ejemplos, ¿quién se enorgullecerá de haberse desprendido de todos sus bienes terrenos, mucho menos queridos que los hijos, por fidelidad a las leyes de la Patria inmortal?

${ }^{76}$ Virgilio, Eneida, 6, 820-825 (2000, p. 190).

77 Torcuato, general y cónsul romano quien ejecutó a su propio hijo por desobediencia, a pesar de haber triunfado en combate cuerpo a cuerpo. (Tito Livio, Historia de Roma..., VIII, 7 (1990c, pp. 28-30)). 
Furio Camilo ${ }^{78}$, que había librado a Roma del yugo de los veyos, sus enemigos más encarnizados, y había sido víctima de la envidia, de nuevo volvió a liberar a su ingrata patria de la amenaza de los galos, por no tener otra mejor donde vivir gloriosamente. ¿Por qué, entonces, se va a dar importancia, como si hubiera hecho algo grande, aquel que por pertenecer a la Iglesia haya sido víctima quizá de alguna grave y deshonrosa injuria por parte de sus enemigos humanos, sin pasarse a sus contrarios, los herejes, ni fundar él mismo una nueva secta, opuesta a la Iglesia, sino que más bien la defendió con todas sus fuerzas contra la perversidad tan perniciosa de los herejes, no teniendo otra patria, no digo donde vivir con gloria de hombres, sino donde poder adquirir una vida eterna?

Mucio $^{79}$, para hacer las paces con el rey Porsena, que tenía a Roma en gravísimos apuros por una guerra, le dio tal coraje de no haber podido dar muerte al mismo Porsena, matando a otro en su lugar por equivocación, que ante sus propios ojos extendió su mano derecha sobre un altar en llamas, diciéndole que otros muchos romanos, tal y como le estaba viendo a él, se habían conjurado para su exterminio. Porsena, asustado de este coraje y de una tal conjuración, puso fin a aquella guerra firmando inmediatamente la paz. Y en el reino de los cielos, ¿quién va a darse títulos meritorios si por amor a él ha entregado a las llamas no una mano, ni espontáneamente, sino el cuerpo entero, sufriendo la persecución de algún enemigo?

Curcio $^{80}$, vestido con sus armas, espoleó a su caballo a carrera tendida y se lanzó a un precipicio, obedeciendo a un oráculo de sus dioses que le ordenaban arrojar al precipicio lo mejor que ellos, los romanos, tuviesen. No encontraron nada más excelente que sus hombres y sus armas. La consecuencia era clara: debía arrojarse mortalmente a aquel precipicio un guerrero armado. Y ahora, ¿dirá haber hecho algo grande por la Patria eterna quien, teniendo que sufrir a un enemigo de su fe, llegase a morir, no arrojándose él a una muerte como la de Curcio, sino arrojado él por su enemigo? Y mucho menos habiendo recibido de su Señor, Rey él mismo de su Patria, este oráculo infalible: No tengáis miedo a los que matan el cuerpo, pero no pueden matar el alma ${ }^{81}$.

Si los Decios ${ }^{82}$, consagrándose de algún modo por determinadas fórmulas, se entregaron a la muerte para que con su ruina y el apacigua-

78 Tribuno militar, derrotó a los galos en 387-386 a.C., y conquistó la ciudad etrusca de Veyos. Fue acusado de apropiarse injustamente de parte del botín proveniente de Veyos, y fue enviado al exilio. (Tito Livio, Historia de Roma..., V, 21; 32; 49-55 (1990b, pp. 140-142; 157-159; 182-193)).

${ }^{79}$ Escévola. Véase nota 70.

80 Véase nota 70.

81 Mateo 10,28.

82 Véase nota 70. 
miento de los dioses con su sangre quedase libre el ejército romano, ¿se van a enorgullecer de algún modo los santos mártires como si hubieran realizado algo digno por participar de la celeste Patria, donde reside la eterna y auténtica felicidad, si tuvieron que luchar hasta derramar su sangre, sin dejar de amar no sólo a sus hermanos, sino también a sus mismos enemigos homicidas, fieles al precepto del Señor, con fe en el amor y con amor a su fe?

Marco Pulvilo ${ }^{83}$, cuando estaba dedicando el templo de Júpiter, Juno y Minerva ${ }^{84}$ recibió la noticia — falsamente dada por los envidiosos— de la muerte de su hijo para que la turbación de una noticia así le hiciera retirarse, quedándose su colega con la gloria de esta dedicación. Pero él no hizo caso, ordenando incluso que el cadáver fuera arrojado sin sepultura. ¡Hasta este punto la pasión por la gloria había prevalecido en su corazón al dolor por la pérdida de un ser querido! ¿Y vamos a decir que ha hecho algo extraordinario por la predicación del Evangelio (gracias a la cual los ciudadanos de la soberana Patria, después de abdicar sus errores, viven unidos) aquel que, preocupado por la sepultura de su hijo, recibió esta respuesta del Señor: Sígueme y deja que los muertos entierren a sus muertos ${ }^{85}$ ?

M. Régulo ${ }^{86}$, para no quebrantar el juramento dado a sus más encarnizados enemigos, desde la misma Roma volvió a ellos de nuevo. Se dice que los romanos lo querían retener, pero él les contestó que, después de haber sido esclavo de los africanos, no podría conservar ya en Roma la dignidad de un ciudadano honrado. Luego los cartagineses, en vista de que su acción ante el Senado romano fue contra ellos, le infligieron la muerte en medio de atroces tormentos. Y ahora, ¿qué tormentos no deberán despreciarse por la fe en aquella Patria, cuando es esta misma fe quien nos conduce a la felicidad? O ¿cómo pagar al Señor todo el bien que ha hecho ${ }^{87}$ si por la fidelidad a Él debida tuviera un hombre que padecer los mismos tormentos que Régulo padeció por la fidelidad debida a sus más crueles enemigos?

¿Cómo un cristiano se atreverá a engreírse de haber abrazado la pobreza voluntaria para caminar más ligero en la peregrinación de esta vida que nos conduce hasta la Patria, donde se entra en posesión de la verdadera riqueza, el mismo Dios, cuando oye o lee que Lucio Valerio ${ }^{88}$, muerto en

\footnotetext{
${ }^{83}$ Cónsul romano en el 509 y 507 a.C. Tito Livio relata esta historia en Historia de Roma..., II, 8 (1990a, pp. 281-282).

${ }^{84}$ Diosa romana de la sabiduría y las artes, identificada con la diosa griega Atenea, y por ende a veces también considerada diosa de la guerra.

85 Mateo 8,22.

${ }^{86}$ Cónsul romano en 267 y 256 a.C.

87 Salmos 116,12.

88 Tito Livio, Historia de Roma..., III, 16 (1990a, p. 295).
} 
el período de su consulado, fue pobre hasta el extremo de tener que proporcionarle sepultura con las aportaciones voluntarias del pueblo; cuando oye o lee que Quintio Cincinato ${ }^{89}$, dueño de cuatro yugadas de tierra, cultivadas con sus propias manos, desde el arado fue conducido para ser proclamado dictador, magistratura superior a la de cónsul, y una vez vencidos los enemigos, cubriéndose él de gloria, permaneció en la misma pobreza?

¿Quién alzará la voz como si hubiera hecho algo grande, cuando, dejando a un lado las recompensas de este mundo, sólo se haya dejado seducir por el atractivo que le inspira la sociedad de aquella eterna Patria, al tener noticia de que Fabricio no pudo ser apartado de Roma ${ }^{90}$, a pesar de las suntuosas ofertas de Pirro, rey del Epiro, con la promesa incluso de la cuarta parte de su reino, prefiriendo vivir allí en su pobreza como simple ciudadano?

Esta era, en efecto, la realidad: aquellos hombres mantenían la República, es decir, la empresa del pueblo, la empresa de la patria, la empresa común, rica hasta la opulencia, al tiempo que en sus propios hogares eran tan pobres que en cierta ocasión uno de ellos, cónsul por dos veces, fue expulsado de aquel senado de pobres, con la acusación censoria de habérsele encontrado diez libras de plata en vajilla. De tal categoría era su pobreza, que las ganancias de sus triunfos pasaban a enriquecer el tesoro público. Pues bien, ¿̇no tienen aquí un motivo para no darse aires jactanciosos todos aquellos cristianos que, movidos por un deseo más elevado, ponen sus riquezas en común, según el pasaje de los Hechos de los Apóstoles: "Se distribuía a cada uno según su necesidad, y nadie llamaba propio a nada, sino que todo era común”91, y esto por conseguir la compañía de los ángeles, cuando los romanos han hecho casi otro tanto para mantener la gloria de Roma?

3. Todas estas heroicidades y otras parecidas que se pueden encontrar en su literatura, ¿cuándo iban a adquirir una tal celebridad, cuándo se iban a divulgar con tanta fama si el dominio de Roma, extendido a lo largo y a lo ancho de la geografía, no hubiese alcanzado su grandeza a través de brillantes acontecimientos? Así, aquel imperio tan vasto, tan duradero, tan célebre y glorioso por las virtudes de unos hombres tan eminentes, sirvió como recompensa de sus aspiraciones, y para nosotros es una lección ejemplar y necesaria: si por la gloriosa Ciudad de Dios no practicamos las virtu-

\footnotetext{
${ }^{89}$ Designado dictador de Roma en 458 a.C. Tito Livio, Historia de Roma..., III, 26 (1990a, pp. 415-417). La república romana contaba con la posibilidad de otorgar poderes de excepción a un dictador en situaciones de crisis.

${ }^{90}$ Fabricio fue enviado como embajador a Epiro, y rechazó las ofertas de soborno del rey Pirro en 280-279 a.C.

91 Hechos 2,44-45; 4,32.
} 
des que han practicado los romanos, de una manera más o menos parecida, por la gloria de la ciudad terrena, debemos sentir el aguijón de la vergüenza. Y si las practicamos, no tenemos por qué engreírnos orgullosamente, porque, como dice el Apóstol, los sufrimientos del tiempo presente son cosa de nada comparados con la gloria que va a revelarse, reflejada en noso$\operatorname{tros}^{92}$. La vida de aquellos hombres sí se consideraba suficientemente digna de la gloria humana, una gloria del tiempo presente.

De ahí que a la luz del Nuevo Testamento, oculto en el Antiguo, que nos inculca la adoración del único y verdadero Dios, no para obtener beneficios temporales y terrenos, concedidos por la divina Providencia juntamente a buenos y malos, sino por la vida eterna, por las recompensas sin término y por vivir asociados a la ciudad celestial; a la luz — repito- del Nuevo Testamento, los judíos, asesinos de Cristo, con toda justicia han sido entregados para gloria de los romanos. Así, era justo que quienes persiguieron y alcanzaron la gloria terrena con toda clase de virtudes, venciesen a quienes con sus arraigados vicios rechazaron y mataron al Dador de la gloria verdadera y de la ciudadanía eterna.

\section{CAPÍTULO XIX}

DIFERENCIA ENTRE LA PASIÓN DE LA GLORIA Y LA PASIÓN DE DOMINIO

Entre la pasión por la gloria humana y la pasión por el dominio hay, evidentemente, una diferencia. Es fácil que quien se complace excesivamente en la gloria de los hombres sienta también con ardor el deseo de dominio. Sin embargo, los que aspiran a la auténtica gloria, aunque sea de las alabanzas humanas, ponen mucho cuidado en no desagradar a quienes juzgan la vida con equilibrio. Hay, en efecto, muchos aspectos buenos de la conducta, que gran número de hombres valoran correctamente, aunque la mayoría carezcan de ellos. Por estos valores morales de la conducta es como aspiran a la gloria, al poder y al dominio aquellos de quienes dice Salustio: "Este lo hace por un camino legítimo"93.

Pero el que sin tener ambiciones de la gloria que le infunde al hombre temor de desagradar a los jueces de rectos criterios, ambiciona el dominio y el poder, llega incluso con frecuencia a buscar, por los caminos declarados del crimen, aquello que pretende. Por eso, el ambicioso de la gloria, o la busca por caminos legítimos, o bien lo intenta, sin lugar a dudas con astucias y trampas, queriendo aparecer un hombre honrado, sin serlo.

\footnotetext{
92 Romanos 8,18.

93 Salustio, Conjuración de Catilina, 11, 2 (2000, p. 12).
} 
¡Qué gran virtud es en el hombre, ya virtuoso por otros conceptos, el despreciar la gloria! Este desdén lo conoce Dios perfectamente, aunque queda oculto al juicio de los hombres. Todo lo que a sus ojos realice para que vean que desprecia la gloria puede ocurrir que sea tomado por algunos sospechosos como un intento para buscar alabanzas, o, en otras palabras, una mayor gloria personal, sin que pueda demostrarles que es distinto de como sospechan de él. Pero el que desprecia el juicio de los aduladores, desprecia también la temeridad de los sospechosos, aunque no su salvación; si se trata de un hombre realmente bueno: tiene tal poder la bondad de quien ha recibido las virtudes del Espíritu de Dios, que ama incluso a sus enemigos, y los ama hasta el punto de querer la conversión de sus enemigos y calumniadores para tenerlos como compañeros no en la patria terrena, sino en la suprema. Y en cuanto a sus admiradores, aunque tenga en poca estima sus alabanzas, no menosprecia, en cambio, el ser amado por ellos: no quiere engañar a quienes alaban; no sea que decepcione a quienes aman. Esta es la razón por la que el justo ardientemente procura que las alabanzas vayan dirigidas a Aquel que es fuente de cuanto en el hombre merece una justa alabanza.

Pero si hay un ser humano que, despreciando la gloria, está ávido de dominio, éste supera a las bestias, ya sea en crueldad, ya sea en lujuria. Así fueron algunos romanos: no por haber perdido la preocupación por la estima carecieron de ambición de dominio. La historia nos proporciona muchos de estos ejemplos. Pero el primero que alcanzó la cumbre, y, como si dijéramos, el colmo de este vicio, fue el César Nerón ${ }^{94}$, cuya lujuria fue tan corrompida que de él nadie parecía temer arranque alguno viril; y su crueldad fue tal que, de no haberlo conocido, nadie creería en él un solo rasgo afeminado.

También a esta clase de hombres les concede el poder únicamente la providencia del Dios supremo cuando juzga dignas de tales gobernantes las empresas humanas. Sobre este punto es clara la voz de Dios. He aquí las palabras de la divina Sabiduría: Por mí reinan los reyes, y por mí tienen dominio sobre la tierra los tiranos ${ }^{95}$. Y no se piense que el término "tirano" se refiere no precisamente a los reyes perversos y déspotas, sino, según la acepción arcaica, a los valientes. (Así dice un verso de Virgilio: "Será para mí prenda de paz haber estrechado la diestra de un tirano"96.) Para

\footnotetext{
${ }^{94}$ Emperador romano, 54-68. Provocó la persecución de los cristianos en el 65.

95 Proverbios 8,15.

${ }^{96}$ Virgilio, Eneida, 7, 266 (2000, p. 207). El término "tirano" originalmente no tenía una connotación negativa.
} 
evitar esta interpretación, dice en otro lugar claramente la Escritura de Dios: Que nombra rey a un bribón por la perversidad del pueblo ${ }^{97}$.

Ya he explicado suficientemente, según mis posibilidades, cuáles han sido las razones por las que el Dios único, verdadero y justo, ha prestado su ayuda a los romanos, que fueron buenos según ciertos criterios de la ciudad terrena, para conseguir la gloria de tan grandioso imperio. Con todo, pueden existir otras causas ocultas según los diversos merecimientos del humano linaje, conocidas más por Dios que por nosotros. De hecho, entre las personas auténticamente religiosas es incontrovertible que sin la verdadera piedad, es decir, sin el auténtico culto al Dios verdadero, nadie es capaz de poseer la verdadera virtud, y ésta deja de ser verdadera cuando se supedita a la gloria humana. En cuanto a los que no son ciudadanos de la ciudad eterna, llamada por nuestras sagradas letras Ciudad de Dios, son más útiles a la ciudad terrena cuando poseen la virtud, aunque nada más sea la gloria humana, que cuando ni siquiera ésta poseen.

Pero los que, dotados de una piedad verdadera, llevan una vida intachable, si poseen las ciencias del gobierno de los pueblos, no hay nada más feliz para las empresas humanas cuando da la coincidencia de que, por la misericordia de Dios, tienen el poder en sus manos. Esta clase de hombres, por muy excelsas que sean sus virtudes, las atribuyen exclusivamente a la gracia de Dios, que a instancias de sus deseos, de su fe y de sus súplicas se las ha concedido. Son conscientes, al mismo tiempo, de todo lo que les falta hasta llegar a la perfección de la justicia, a la medida de como se practica en aquella sociedad de los santos ángeles, para la cual ellos se esfuerzan en disponerse. Y por mucho que se alabe y se pregone la virtud, que, privada de la verdadera piedad, está al servicio de la gloria humana, no admite comparación con los comienzos más pequeños de los santos, cuya esperanza se apoya en la gracia y en la misericordia del verdadero Dios.

\section{CAPÍTULO XX}

\section{SOMETER LAS VIRTUDES A LA GLORIA HUMANA ES TAN VERGONZOSO COMO SOMETERLAS A LAS PASIONES CORPORALES}

Los filósofos que en la virtud ponen el bien supremo del hombre ${ }^{98}$, pretenden avergonzar a otros filósofos ${ }^{99}$ que aprueban, es cierto, las virtudes, pero las miden por el rasero del placer corporal, su fin último, al que

\footnotetext{
97 Job 34,30 (Vulg.).

${ }^{98}$ Los estoicos. Véase Long (1986), pp. 179-209.

99 Los epicúreos. Véase Long (1986), pp. 61-69.
} 
hay que tender — dicen — y apetecer por sí mismo, y las virtudes únicamente sometidas a é1. Para lograr este objeto suelen pintar, de palabra, un curioso cuadro: el placer (voluptas), como si fuera una delicada reina, sentada en un trono real. A su alrededor, y sometidas a ella, sus esclavas, las virtudes, pendientes del menor gesto de su reina para cumplir lo que ella ordena. Da órdenes a la prudencia para investigar con vigilancia el modo más oportuno de continuar el reinado y la seguridad de la sensualidad. A la justicia le da órdenes para que haga todos los beneficios que estén a su alcance con objeto de conseguir las amistades necesarias para la satisfacción del cuerpo; que no haga injuria a nadie, no sea que la transgresión de las leyes imposibilite la seguridad del placer. Da órdenes a la fortaleza para que si sobreviene un dolor corporal que no arrastre a la muerte, mantenga valientemente en su pensamiento a su señora, es decir, la sensualidad placentera, para que el recurso de las delicias pasadas mitigue el aguijón de los presentes dolores. A la templanza le da órdenes para que ponga mesura en los alimentos y demás deleites, no sea que el exceso inmoderado y perjudicial llegue a alterar la salud corporal, con lo que quedaría gravemente perjudicada su reina, el placer, que, según los epicúreos, reside principalmente en una buena salud corporal.

De esta suerte, las virtudes, con toda su gloriosa dignidad, quedan esclavizadas por el placer, como si fuera una mujerzuela mandona e impúdica. Nada más ignominioso, más deforme, más insoportable que la visión que ofrece este cuadro a los hombres de bien, dicen estos filósofos; y dicen bien. Pero si imaginamos otra pintura parecida, representando las virtudes al servicio de la gloria humana, no creo que quedase debidamente reflejada la belleza que se merece. Porque, aunque la gloria humana no sea una mujer sensual, sí está, y en sumo grado, hinchada y llena de vanidad. Por ello es indigno de la peculiar solidez y firmeza de las virtudes rebajarse como esclavas, de forma que nada programe la prudencia, nada distribuya la justicia, nada soporte la fortaleza y nada modere la templanza, si no es del agrado de los hombres y se somete a la hueca gloria.

Y que no traten de excusarse de este baldón quienes, insensibles a la estima ajena y menospreciando la gloria, se complacen en sí mismos, teniéndose por sabios. Su virtud — si es que existe alguna— está sometida de otra manera a una cierta alabanza humana, ya que quien se complace en sí mismo, no es otra cosa que un hombre. Pero el que tiene una auténtica actitud religiosa, creyendo, esperando y amando a Dios, pone más interés por las cosas que le desagradan a Él que por aquellas — si alguna hay en él— que le agradan no a sí mismo, sino a la verdad. Y todo esto, que podía darle pie a 
la complacencia, lo atribuye únicamente a la misericordia de Aquel a quien teme desagradar, dándole gracias por las llagas curadas y elevando súplicas por las que aún le quedan por curar.

\section{CAPÍTULO XXI}

LA SOBERANÍA DE ROMA HA SIDO DISPUESTA POR EL DIOS VERDADERO, DE QUIEN VIENE TODO PODER Y CUYA PROVIDENCIA LO GOBIERNA TODO

A la vista de lo expuesto no atribuyamos la potestad de distribuir reinos e imperios más que al Dios verdadero. Él es quien da la felicidad, propia del reino de los cielos, a sólo los hombres religiosos. En cambio, el reino de la tierra lo distribuye a los religiosos y a los impíos, según le place, Él, que en ninguna injusticia se complace. $\mathrm{Y}$ aunque hayamos expuesto algo de lo que ha tenido a bien descubrirnos, no obstante es demasiado para nosotros, supera con mucho nuestras posibilidades el desvelar los misterios del hombre y emitir un juicio claro sobre los méritos de cada reino.

Ha sido el único y verdadero Dios, que no abandona al género humano sin sentenciar su conducta, y sin prestar ayuda a su actuación, quien dio a los romanos la soberanía cuando Él quiso y en la medida que Él quiso; Él, quien la dio a los asirios y también a los persas, adoradores únicamente de dos dioses, el uno bueno y malo el otro, según nos revelan sus escrituras. Esto por no citar al pueblo hebreo, del cual ya he hablado suficientemente, creo, y que no dio culto más que a un solo Dios, incluso durante el período de su monarquía. Él quien a los persas dio las mieses sin el culto a la diosa Segetia ${ }^{100}$. Él quien ha concedido tantos y tantos dones terrenos sin adorar a un sinfín de dioses como los romanos designaron, uno para cada cosa, y hasta varios para una misma realidad. Él mismo ha sido quien les concedió la soberanía, sin el culto de los dioses a quienes los romanos atribuían su Imperio.

Algo semejante ha sucedido con las personas: el que entregó a Mario ${ }^{101}$ el poder es el mismo que se lo dio a Cayo César ${ }^{102}$; quien lo entregó a Augusto $^{103}$, lo dio también a Nerón ${ }^{104}$; quien lo puso en manos de los Vespasianos ${ }^{105}$, emperadores humanos en sumo grado, tanto el padre como

${ }^{100}$ Diosa romana de los campos de maíz.

101 General y cónsul romano (157-86 a.C).

102 Julio César, dictador de Roma en el 48 a.C.

103 Primer emperador de Roma, 27 a.C.-14 d.C.

104 Emperador romano, 54-68.

105 Padre e hijo, emperadores romanos entre 69-79 y 79-81, respectivamente. Ambos conocidos por su moderación y justicia. 
el hijo, lo puso también en las del cruel Domiciano ${ }^{106}$; y, para no recorrerlos todos, quien concedió el Imperio al cristiano Constantino ${ }^{107}$, se lo dio también a Juliano el Apóstata ${ }^{108}$, de noble índole, pero traicionado por su ambición de poder y su sacrílega y detestable curiosidad. Esta última le llevó a entregarse a estúpidos oráculos, cuando mandó quemar las naves, cargadas del necesario avituallamiento, seguro como estaba de la victoria. Luego, confiando ardorosamente en sus descabellados planes, pronto pagó con la vida su temeridad, dejando al ejército hambriento y rodeado de enemigos. No hubiera podido escapar de allí si, en contra del famoso augurio del dios Término ${ }^{109}$, tratado en el libro anterior, no se hubieran cambiado las fronteras del Imperio Romano. El dios Término, que no había cedido ante Júpiter, tuvo que ceder ante la necesidad.

Todos estos avatares de la Historia es, sin lugar a dudas, el Dios único y verdadero quien los regula y gobierna, según le place. Quizá los motivos sean ocultos. Pero ¿serán por ello menos justos?

\section{CAPÍTULO XXIV}

\section{FELICIDAD DE LOS EMPERADORES CRISTIANOS; SU AUTENTICIDAD}

Si llamamos felices a algunos emperadores cristianos, no es precisamente por haber reinado largo tiempo, o porque, tras una muerte plácida, dejaron a sus hijos en el poder, o humillaron a los enemigos del Estado, o supieron prevenirse contra la enemistad de sus súbditos rebeldes y los aplastaron. Estos y otros favores, o, si se prefiere, consuelos de esta trabajosa vida merecieron recibirlos algunos de los adoradores de demonios, no pertenecientes al reino de Dios, como estos emperadores. También sucedió así por la misericordia de Dios, para que quienes creen en Él no suspiren por estos favores suyos como si fueran el bien supremo.

Llamamos realmente felices a los emperadores cristianos cuando gobiernan justamente; cuando en medio de las alabanzas que los ponen por las nubes, y de los homenajes de quienes los saludan humillándose excesivamente, no se engríen, recordando que no son más que hombres; cuando someten su poder a la majestad de Dios, con el fin de dilatar al máximo su

\footnotetext{
106 Emperador entre 81 y 96. Conocido por su crueldad, en especial durante la persecución de los cristianos que impulsó.

107 Emperador (306-337). Se convirtió al cristianismo durante su reinado, y, a través del Edicto de Milán en 313, puso fin a las persecuciones de los cristianos.

108 Emperador entre 361-363. Llamado “el apóstata” porque quiso reinstaurar la religión pagana en el Imperio.

109 Dios romano de las fronteras.
} 
culto; cuando temen a Dios, lo aman, lo adoran; cuando tienen más estima por aquel otro reino, donde no hay peligro dividir el poder con otro; cuando son lentos en tomar represalias, y prontos en perdonar; cuando tales represalias las toman obligados por la necesidad de regir y proteger al Estado, no por satisfacer su odio personal; cuando conceden el perdón no para dejar impune el delito, sino por la esperanza de la corrección; cuando, puestos con frecuencia en la desagradable obligación de dictar medidas severas, lo compensan con la dulzura de su misericordia y la magnificencia de sus beneficios; cuando cercenan con tanto más rigor el desenfreno, cuando son más libres de entregarse a él; cuando prefieren tener sometidas sus bajas pasiones antes que a país alguno, y esto no ardiendo en deseos de gloria vana, sino por amor a la felicidad eterna; cuando no son negligentes en ofrecer por sus pecados al Dios verdadero, que es el suyo, un sacrificio de humildad, de propiciación y de súplica.

A estos emperadores los proclamamos felices; ahora en esperanza, y después en realidad, cuando llegue lo que esperamos.

\section{CAPÍTULO XXV}

\section{PROSPERIDAD CONCEDIDA POR DiOS AL EMPERADOR CRISTIANO CONSTANTINO}

Dios, que es bueno, quiso impedir en quienes tenían como un deber adorarle para conseguir la vida eterna, la convicción de que es necesario suplicar a los demonios para conseguir altas dignidades, e incluso la soberanía terrena, dado el supuesto poder de tales espíritus en este campo. Para ello, a Constantino, que no suplicó a los demonios, sino que adoraba al verdadero Dios, lo colmó de tan encumbrados favores terrenos como nadie se atrevería a desear. Le concedió también fundar una ciudad asociada al Imperio Romano ${ }^{110}$, como hija de la propia Roma. Y todo ello sin levantar a los demonios ningún templo, ningún ídolo. Ocupó el trono largos años; mantuvo íntegro y defendió todo el mundo romano como único Augusto. A la hora de organizar y realizar las guerras, quedó plenamente victorioso. Tuvo éxito completo en la lucha contra las tiranías. Murió de avanzada edad, por enfermedad y decrepitud, dejando el poder a sus hijos ${ }^{111}$.

Pero luego, para evitar que cualquier emperador se hiciera cristiano para conseguir la felicidad de Constantino, siendo así que la única razón del ser cristiano es la vida eterna, privó de esta felicidad a Joviano mucho antes

\footnotetext{
110 Constantinopla, fundada en el año 330.

111 Constantino II, Constante y Constancio.
} 
que a Juliano ${ }^{112}$; permitió que Graciano fuera asesinado por una tiránica espada ${ }^{113}$ en circunstancias, es cierto, mucho menos crueles que el gran Pompeyo ${ }^{114}$, adorador de los pretendidos dioses romanos. En efecto, él no pudo ser vengado por Catón ${ }^{115}$, a quien había nombrado heredero, por así decir, de la guerra civil; en cambio, Graciano - a pesar de que las almas religiosas no apetecen tales desahogos- fue vengado por Teodosio ${ }^{116}$, hecho por él partícipe del poder, no obstante tener un joven hermano: más interesado en un fiel consorcio que en un poderío excesivo.

\section{CAPÍTULO XXVI}

Fe y RELIGIOSIDAD DEL AUgusto TEOdosio

1. No se contentó Teodosio con guardarle fidelidad en vida a Graciano. Después de su muerte acogió a su joven hermano Valentiniano ${ }^{117}$ en su imperio, expulsado antes por el asesino Máximo ${ }^{118}$. Recibió al huérfano cristianamente, y veló por él con afecto paternal, en lugar de quitarlo de en medio sin dificultad alguna, desprovisto como estaba de todo recurso, si su alma estuviese inflamada en deseos de ensanchar sus dominios, más que en el amor de hacer el bien. Le conservó su dignidad imperial y le trató con toda delicadeza y generosidad.

Este desenlace encendió peligrosamente la cólera de Máximo. Teodosio, en medio de sus angustiosas preocupaciones, no cayó en curiosidades sacrílegas e ilícitas: envió mensajeros a consultar a un tal Juan ${ }^{119}$, ermitaño en el desierto egipcio, siervo de Dios, cuya fama se iba extendiendo, y que llegó hasta él como dotado de espíritu de profecía. Este le predijo una victoria segura. Exterminado por fin Máximo, repuso con una estimación llena de ternura al joven Valentiniano en la porción de su imperio, de donde

\footnotetext{
112 Joviano sucedió a Juliano el Apóstata (361-363), y duró sólo unos ocho meses como emperador entre junio 363 y febrero 364.

113 Emperador cristiano del Imperio Occidental entre 367 y 383 . Fue asesinado al acercarse las tropas de Máximo que buscaban derrocarlo.

114 Pompeyo (106-48 a.C.) fue miembro del primer triunvirato junto a Julio César y Craso. Luego del quiebre entre César y Pompeyo, este último huyó a Egipto, pero fue asesinado al llegar.

115 Catón de Útica fue nombrado sucesor de Pompeyo, pero se suicidó al ser derrotado este último.

116 Teodosio I, designado emperador del Imperio de Oriente por Graciano en el año 379.

117 Teodosio restituye a Valentiniano II, hermano de Graciano.

118 Emperador entre 383-388. Comandante de las tropas romanas en Bretaña quien derroca a Graciano. Teodosio I lo derrota luego de la expulsión de Valentiniano.

119 San Juan de Egipto (300-394).
} 
había tenido que huir. Murió pronto el joven, no sé si por intrigas o por otra razón, o accidentalmente, y Teodosio acabó con otro tirano, Eugenio ${ }^{120}$, ilegítimamente puesto en el trono del joven emperador, después de haber recibido nueva respuesta profética favorable. La lucha contra el poderoso ejército de Eugenio fue más bien con la oración que con las armas. Soldados que asistieron a este combate nos han descrito como un viento fuerte del lado de Teodosio les arrancaba de las manos las armas arrojadizas, lanzándolas contra los enemigos; y no sólo les arrancaba violentamente todo lo que arrojaban contra ellos, sino que volvía los dardos enemigos contra los propios cuerpos de éstos.

De ahí que el poeta Claudiano ${ }^{121}$, aunque adversario al cristianismo, pudo exclamar en sus elogios a Teodosio: “ ¡Oh tú, predilecto de Dios, por quien Eolo ${ }^{122}$, desde sus antros, despliega los armados huracanes; por quien lucha el éter, y acuden los vientos, conjurados al toque de las trompetas!”

Vencedor, como había creído y predicho, derribó unas estatuas de Júpiter que contra él habían sido erigidas y como consagradas con no sé qué ritos en los Alpes. Los rayos que habían tenido estas estatuas, por ser de oro, fueron pedidos entre bromas (lo permitía la circunstancia de la victoria) por los correos, diciendo que querían ser alcanzados por tales rayos. Teodosio, siguiendo la broma, se los concedió con generosidad.

A los hijos de sus enemigos personales, víctimas no de sus órdenes, sino del torbellino de la guerra, y refugiados en las iglesias antes de ser cristianos, les ofreció la ocasión de convertirse al cristianismo. Los amó con caridad cristiana; sin despojarlos de sus bienes, los colmó de honores. No permitió que nadie, después de la victoria, vengase sus enemistades particulares. En las guerras civiles no se portó como Cinna, Mario, Sila ${ }^{123}$ y otros por el estilo, que, una vez terminadas, parecían no querer darles fin nunca: él se dolió de que hubieran surgido, más bien que intentó el mal de nadie después de terminarlas.

En medio de todos estos vaivenes, y desde el comienzo de su mandato, no cesó de apoyar en sus dificultades a la Iglesia con leyes, las más

\footnotetext{
${ }^{120}$ Proclamado emperador luego de la muerte de Valentiniano II en 392. No fue reconocido por Teodosio I, quien lo derrotó y mató en 394.

121 Poeta romano, nacido en 370 y quien desaparece en el 404. La mayor parte de su poesía consiste en panegíricos a los emperadores como lo que se cita aquí.

122 Dios romano de los vientos. Nótese el aparente sincretismo religioso de estos versos, en los que el cristianismo y el paganismo parecen confundirse. Para este tema en general, véase Brown (1997).

123 Cinna, cónsul romano en el 87 a.C., aliado de Mario, enemigos ambos del dictador Sila. La guerra civil en la que participaron (88-82 a.C.) fue particularmente cruenta y salvaje.
} 
justas y benignas, contra los impíos. El hereje Valente ${ }^{124}$, partidario de los $\operatorname{arrianos}^{125}$, la había perseguido duramente. Se preciaba mucho más de ser un miembro de la Iglesia que de tener bajo su dominio el orbe entero. Dio orden de derribar por todas partes los ídolos de los gentiles, dándose cuenta con lucidez de que la facultad de conceder los bienes, incluso de la tierra, no reside en los demonios, sino en el Dios verdadero.

¿Hay algo más admirable que su religiosa humildad cuando sucedió el gravísimo crimen de los tesalonicenses? ${ }^{126}$ La intercesión de los obispos había conseguido de él una promesa de indulgencia para el crimen; pero presionado por un levantamiento de sus partidarios, se vio obligado a tomar una represalia. Castigado después él por la disciplina eclesiástica, de tal forma hizo penitencia que el pueblo, orando por él, lloró más al ver postrada en tierra la majestad imperial, que la había temido encolerizada por su pecado.

En estas buenas acciones y otras parecidas, que sería prolijo enumerar, llevó siempre consigo el desprendimiento de cualesquiera humos que supone el encumbramiento y la exaltación humana. La recompensa de tales obras es la eterna felicidad, cuyo dispensador es Dios para solos los hombres que realmente vivan una vida religiosa.

Los demás dones de esta vida, como pueden ser los honores y la abundancia de bienes, Dios los concede tanto a malos como a buenos, del mismo modo que les concede el mundo, la luz, la brisa, los campos, el agua, los frutos, como también el alma y el cuerpo del hombre mismo, y los sentidos, y la inteligencia, y la vida. Entre ellos se encuentra el poder, cualquiera que sea su magnitud, y que Dios dispensa según el gobierno de cada tiempo.

2. Así, pues, veo que es preciso también dar una respuesta a aquellos que, refutados y convencidos de su error por pruebas evidentes que demuestran la absoluta inutilidad de la muchedumbre de dioses falsos para lograr los bienes temporales, a los que sólo aspiran los insensatos, siguen todavía empeñados en afirmar que es necesario dar culto a tales dioses no

\footnotetext{
124 Emperador del Imperio Oriental entre 364-378.

125 Doctrina cristiana, posteriormente considerada herética, formulada originalmente por el sacerdote Ario (250-336), que rechazaba la consubstancialidad del Padre, el Hijo y el Espíritu Santo, y que establecía una jerarquía entre ellos. En efecto, por lo tanto, negaba la doctrina de la Santísima Trinidad. Es de notar que Alarico, líder de los visigodos, y cuya invasión de Roma fue la causa inmediata de la composición de La Ciudad de Dios, era arriano.

${ }^{126}$ En el año 390 una muchedumbre en Tesalónica linchó a pedradas al gobernador romano y a otros oficiales en represalia por el encarcelamiento de un auriga de gran popularidad. Teodosio I ordenó a sus soldados castigar ferozmente a la muchedumbre, causando una masacre de proporciones. El obispo San Ambrosio obligó al emperador a hacer una penitencia pública.
} 
por el interés de esta vida, sino por la que nos aguarda después de la muerte.

Creo, en efecto, haber dado cumplida respuesta en los cinco libros precedentes a todos esos que por el apego a este mundo pretenden dar culto a realidades inexistentes, y que se quejan de que se les pone veto a estas posturas infantiles. Los tres primeros libros ya están publicados, y han empezado a correr de mano en mano. He oído que algunos están preparando no sé qué réplica contra ellos. Después ha llegado a mis oídos que ya estaba escrita, pero que sus autores esperaban el momento propicio para editarla sin peligro. Les advierto a éstos que no se hagan ilusiones de conseguir lo que pretenden. Es fácil creer que se ha dado una respuesta, cuando en realidad lo que se ha querido es no callar. ¿̇Hay algo más charlatán que la estupidez? Nunca tendrá más fuerza que la verdad, aunque podrá, si quiere, vocear más que ella.

Pero que pongan atención a todos los puntos, y si por casualidad, en un examen sin prejuicios, llegan a descubrir que, más que replicar, lo que pueden es importunar con su garrulería desvergonzada y con su ligereza entre satírica y mímica, déjense de simplezas y decídanse más bien por la corrección de los sensatos que por las adulaciones de los insensatos. Porque si lo que están esperando no es la ocasión de decir francamente la verdad, sino de lanzar insultos a rienda suelta, ojalá no les sobrevenga lo que dice Cicerón de uno que se llamaba feliz por tener la libertad de hacer el mal: “iPobre de ti, que tenías permiso para pecar!”127

Así que quienquiera que se sienta feliz porque tiene la posibilidad de lanzar improperios, será mucho más feliz si renuncia totalmente a ella. Puede poner desde ahora mismo todas las objeciones que quiera, como en un diálogo de investigación, con tal que renuncie a toda pretenciosa vanidad. Tendrá ocasión de oír, en amigable discusión, una respuesta oportuna, honesta, seria y sincera de sus interlocutores, en la medida de sus posibilidades.

\section{LIBRO XIV}

\section{CAPÍTULO IV}

QUÉ ES VIVIR SEGÚN EL HOMBRE Y QUÉ VIVIR SEGÚN DiOS

1. Cuando el hombre vive según el hombre, y no según Dios, es semejante al diablo. Ni siquiera el ángel debió vivir según el ángel, sino según Dios, para mantenerse en la verdad y hablar la verdad que procede

${ }^{127}$ Cicerón, Disputaciones Tusculanas (2005), 5, 19, 55. 
de Dios, no la mentira, que nace de su propia cosecha. Del hombre dice el mismo Apóstol en otro lugar: Si es que se manifestó la verdad de Dios en mi mentira ${ }^{128}$. Llamó a lo mío mentira, y verdad a lo de Dios. Y así, cuando el hombre vive según la verdad, no vive según él mismo, sino según Dios, pues es Dios quien dijo: Yo soy la verdad ${ }^{129}$. Pero cuando vive según él mismo, según el hombre, no según Dios, vive según la mentira. No se trata de que el hombre mismo sea la mentira, puesto que tiene por autor y creador a Dios, quien no es autor ni creador de la mentira. La realidad es que el hombre ha sido creado recto no para vivir según él mismo, sino según el que lo creó. Es decir, para hacer la voluntad de aquél con preferencia a la suya. Y el no vivir como lo exigía su creación constituye la mentira.

Quiere ser feliz sin vivir de la manera que podía serlo. ¿Hay algo más mentiroso que esta voluntad? No en vano puede afirmarse que todo pecado es una mentira. No se comete un pecado sino queriendo que nos vaya bien o rehuyendo que nos vaya mal. Tiene, pues, lugar la mentira cuando, intentando buscar algún bien, eso mismo nos resulta mal, o cuando procurando buscar algo mejor, nos resulta, en cambio, peor. ¿De dónde procede esto? De que el bien le viene al hombre de Dios, a quien abandona por el pecado. No le viene de sí mismo, pues si vive según él mismo, peca.

2. Hemos dicho que de ahí procedía la existencia de dos ciudades diversas y contrarias entre sí: unos viven según la carne, y otros según el espíritu. Esto equivale a decir que viven unos según el hombre y otros según Dios. Lo dice con toda claridad San Pablo a los corintios: Mientras haya entre vosotros rivalidad y discordia, ¿no está claro que sois carnales y procedéis según el hombre? ${ }^{130}$ Proceder según el hombre es ser carnal, ya que por la carne, es decir, por una parte del hombre se entiende el hombre. Llamó, en efecto, más arriba animales a los que después llama carnales diciendo: ¿Quién conoce a fondo la manera de ser del hombre, si no es el espíritu del hombre que está dentro de él? Pues lo mismo: la manera de ser de Dios nadie la conoce si no es el Espíritu de Dios. Y nosotros no hemos recibido el espíritu del mundo, sino el Espíritu que viene de Dios; así conocemos a fondo los dones que Dios nos ha hecho. Eso precisamente exponemos no con el lenguaje que enseña el saber humano, sino con el que enseña el Espíritu, explicando temas espirituales a hombres de espíritu. Pero el hombre animal no puede hacerse capaz de las cosas que son del Espíritu de Dios, le parecen una locura ${ }^{131}$. Y a éstos, es decir,

\footnotetext{
128 Romanos 3,7.

129 Juan 14,6.

1301 Corintios 3,3.

1311 Corintios 2,11-14.
} 
a esos hombres animales dice poco después: $Y$ así es, hermanos, que yo no he podido hablaros como a hombres espirituales, sino como a carnales $^{132}$.

También aquí, según ese estilo figurado, se entiende el todo por la parte. Tanto por el alma como por la carne, que son partes del hombre, puede significarse el todo, que es el hombre. Al igual que no se significa otra cosa que hombres cuando se lee: Ninguna carne será justificada por las obras de la ley ${ }^{133}$; o cuando está escrito: Bajaron con Jacob a Egipto setenta y cinco almas ${ }^{134}$. En el primer caso, por toda la carne se entiende el hombre, y en el segundo, setenta y cinco hombres por las setenta y cinco almas. También donde se dijo: No con el lenguaje que enseña el saber humano, podía haber dicho: "No con el lenguaje que enseña el saber carnal”; lo mismo que cuando dice: Procedéis según el hombre, podía hacer dicho: "según la carne". Pero esto se evidencia mejor en lo que añadió: Porque diciendo uno: Yo soy de Pablo, y el otro: Yo de Apolo, ¿no os quedáis en ser hombres? ${ }^{135}$ Las expresiones de antes: Sois animales y sois carnales las expresó con más exactitud: Sois hombres; que quiere decir: vivís según el hombre, no según Dios; si vivierais según Dios, seríais dioses.

\section{CAPÍTULO XXVIII}

Propiedades de las dos CiUdAdes, LA TERRENA y LA CELESTE

Dos amores han dado origen a dos ciudades: el amor de sí mismo hasta el desprecio de Dios, la terrena; y el amor de Dios hasta el desprecio de sí, la celestial. La primera se gloría en sí misma; la segunda se gloría en el Señor. Aquélla solicita de los hombres la gloria; la mayor gloria de ésta se cifra en tener a Dios como testigo de su conciencia. Aquélla se engríe en su gloria; ésta dice a su Dios: Gloria mía, tú mantienes alta mi cabeza ${ }^{136}$. La primera está dominada por la ambición de dominio en sus príncipes o en las naciones que somete; en la segunda se sirven mutuamente en la caridad los superiores mandando y los súbditos obedeciendo. Aquélla ama su propia fuerza en los potentados; ésta le dice a su Dios: Yo te amo, Señor; tú eres mi fortaleza ${ }^{137}$.

\footnotetext{
1321 Corintios 3,1 .

133 Romanos 3,20.

134 Génesis 46,27.

1351 Corintios 3,4.

136 Salmos 3,4.

137 Salmos 18,2.
} 
Por eso, los sabios de aquélla, viviendo según el hombre, han buscado los bienes de su cuerpo o de su espíritu o los de ambos; y pudiendo conocer a Dios, no le honraron ni le dieron gracias como a Dios, sino que se desvanecieron en sus pensamientos, y su necio corazón se oscureció. Pretendiendo ser sabios, exaltándose en su sabiduría por la soberbia que los dominaba, resultaron unos necios que cambiaron la gloria del Dios inmortal por imágenes de hombres mortales, de pájaros, cuadrúpedos y reptiles (pues llevaron a los pueblos a adorar a semejantes simulacros, o se fueron tras ellos), venerando y dando culto a la criatura en vez de al Creador, que es bendito por siempre $e^{138}$.

En la segunda, en cambio, no hay otra sabiduría en el hombre que una vida religiosa, con la que se honra justamente al verdadero Dios, esperando como premio en la sociedad de los santos, hombres y ángeles, que Dios sea todo en todas las cosas ${ }^{139}$.

\section{LIBRO XV}

\section{CAPÍTULO IV}

CONTIENDA Y PAZ DE LA CIUDAD TERRENA

La ciudad terrena, que no será eterna (después de su condenación al último suplicio ya no será ni ciudad), tiene aquí abajo un cierto bien, tomando parte en la alegría que pueden proporcionar estas cosas. Y como no hay bien alguno exento de penurias para sus amadores, esta ciudad se halla dividida entre sí la mayor parte del tiempo, con litigios, guerras, luchas, en busca de victorias mortíferas o ciertamente mortales. Porque cualquier parte de ella que se levanta en son de guerra contra otra parte busca la victoria sobre los pueblos, quedando ella cautiva de los vicios. Y si al vencer se enorgullece con soberbia, su victoria lleva consigo la muerte; pero si, reflexionando sobre su condición y los accidentes comunes, se siente más atormentada por la adversidad que puede sobrevenirle, que engallada por la prosperidad, esa victoria es meramente mortal pues no puede tener sometidos siempre a los que ha subyugado con tal victoria.

No se puede decir justamente que no son verdaderos bienes los que ambiciona esta ciudad, siendo ella en ese su género humano mejor. Busca cierta paz terrena en lugar de estas cosas ínfimas, y desea alcanzarla incluso con la guerra; y si vence y no hay ya quien resista, habrá llegado la paz que

\footnotetext{
138 Romanos 1,21-25.
}

1391 Corintios 15,28 
no podían tener las partes adversarias entre sí, mientras luchaban con infeliz miseria por las cosas que no podían poseer ambas a la vez. Esta es la paz que solicitan las penosas guerras, ésta es la que consigue la victoria tenida por gloriosa. Y cuando triunfan los que luchaban por causa más justa, ¿quién puede dudar en dar el parabién por la victoria y haber llegado a la paz deseable? Bienes son éstos y dones, sin duda, de Dios. Pero si se menosprecian los otros mejores, que pertenecen a la ciudad celeste, morada de la victoria segura, en eterna y suprema paz, y se buscan estos bienes con tal ardor que se los considera únicos o se los prefiere a los tenidos por mejores, la consecuencia necesaria es la desgracia, aumentando la que ya existía.

\section{CAPÍTULO V}

PRIMER AUTOR DE LA CIUDAD TERRENA Y FRATRICIDA. ECO QUE TUVO EN LA IMPIEDAD DEL FUNDADOR DE ROMA AL MATAR A SU HERMANO

El primer fundador de la ciudad terrena fue un fratricida. Dominado por la envidia, dio muerte a su hermano, ciudadano de la ciudad eterna y peregrino en esta tierra. No nos debe extrañar si después de tanto tiempo este primer ejemplo, o, como dicen los griegos, arquetipo, encontró un eco en la fundación de la célebre ciudad que había de ser cabeza de esta ciudad terrena y había de dominar a muchos pueblos. También allí, según el crimen que nos cuenta uno de sus poetas, "los primeros muros se humedecieron con la sangre fraterna" ${ }^{140}$. La fundación de Roma tuvo lugar cuando nos dice la historia romana que Rómulo mató a su hermano Remo, con la diferencia de que aquí los dos eran ciudadanos de la ciudad terrena.

Ambos buscaban la gloria de ser los fundadores del Estado romano. Pero no la podían tener los dos tan grande como uno sólo; quien quería esa gloria de dominio lo tendría más reducido si su poder quedaba disminuido por la participación del hermano vivo. Para tener, pues, uno el dominio entero fue preciso liquidar al otro; creció con el crimen en malicia lo que con la inocencia hubiera sido un bien mejor, aunque más pequeño.

Los hermanos Caín y Abel no tenían entre sí tal apetencia de cosas terrenas; ni el fratricida tuvo envidia de su hermano porque su dominio se iba a reducir si llegaban a dominar ambos (Abel no buscaba dominar en la ciudad que fundaba su hermano); estaba más bien dominado por la envidia diabólica con que envidian los malos a los buenos, sin otra causa que el ser buenos unos y malos los otros. En verdad que jamás llega a ser menor la

${ }^{140}$ Lucano, Farsalia 1, 95 (2001, p. 9). 
posesión de la bondad porque llegue o haya llegado ya otro copartícipe; antes la bondad es una posesión que se dilata tanto más cuanto con más concordia domina el amor individual de los que la poseen. Es más, no será capaz de esta posesión el que no quisiera tenerla en común; y la verá tanto más acrecentada cuanto más ame en ella al que la condivide.

Lo que sucedió entre Rómulo y Remo manifiesta cómo está divida entre sí la ciudad terrena; lo que tuvo lugar entre Caín y Abel puso de manifiesto las enemistades entre las dos ciudades, la de Dios y la de los hombres. Luchan entre sí los malos, y lo mismo hacen buenos y malos. En cambio, los buenos, si son perfectos, no pueden luchar entre sí; pueden hacerlo los que progresan sin ser perfectos, pero de tal modo que el bueno lucha contra otro en la misma parte que contra sí mismo; como en todo hombre, la carne lucha con sus apetencias contra el espíritu y el espíritu contra la carne $e^{141}$. Por consiguiente, el deseo espiritual puede entablar combate contra las apetencias carnales de otro, o las carnales de uno contra las espirituales de otro, como pueden entablarlo entre sí buenos y malos; incluso los mismos apetitos carnales entre sí de dos buenos, no perfectos todavía, como luchan entre sí los malos, hasta que la salud de los que están en recuperación llegue a la victoria definitiva.

\title{
CAPÍTULO VI
}

\begin{abstract}
ENFERMEDADES QUE SOPORTAN EN LA PEREGRINACIÓN DE ESTA VIDA, COMO PENA DEL PECADO, INCLUSO LOS MIEMBROS DE LA CIUDAD DE DIOS, Y DE LAS CUALES SON CURADOS POR LA MEDICINA DEL MISMO
\end{abstract}

Esta enfermedad, es decir, la desobediencia de que hemos hablado en el libro decimocuarto, es el castigo de la primera desobediencia. No es, por lo tanto, una naturaleza, sino un vicio de la misma. Por ello se dice a los buenos que van progresando y viven de la fe en esta peregrinación: Llevad unos las cargas de los otros, que con eso cumpliréis la ley de Cristo ${ }^{142}$. Y también se les dice en otro lugar: Por favor, hermanos, llamad la atención a los ociosos, animad a los apocados, sostened a los débiles, sed pacientes con todos. Mirad que nadie devuelva a otro mal por mal ${ }^{143}$. Y también: Si a un individuo se le cogiere en algún desliz, vosotros, los hombres de espíritu, recuperad a ese tal con mucha suavidad; estando tú sobre aviso,

\footnotetext{
141 Gálatas 5,17.

142 Gálatas 6,2.

1431 Tesalonicenses 5,14-15.
} 
no vayas a ser tentado también tú144. En otro lugar: Que la puesta del sol no os sorprenda en vuestro enojo ${ }^{145}$. Y en el Evangelio: Si tu hermano te ofende, ve y házselo ver, a solas entre los dos ${ }^{146}$. Hablando de los pecados, en los que se puede seguir el escándalo de muchos, dice también el Apóstol: A los que pequen repréndeles públicamente para que los demás escarmienten $^{147}$.

Por eso también, con relación al perdón mutuo, existen muchas prescripciones y se exige cuidado especial a fin de mantener la paz, sin la cual no se puede ver a Dios ${ }^{148}$, cuyo ejemplo es el terror de exigir al siervo los diez mil talentos que se le habían perdonado por no haber condonado él a un consiervo suyo la deuda de cien denarios. Después de propuesta esta parábola, añadió Jesús: Pues lo mismo os tratará mi Padre del cielo si no perdonáis de corazón cada uno a su hermano ${ }^{149}$. De esta guisa son curados los ciudadanos de la ciudad de Dios que peregrinan en la tierra y suspiran por la paz de la patria celeste. Pero el Espíritu Santo obra en lo íntimo a fin de que surta algún efecto la medicina que se emplea exteriormente.

Por lo demás, aunque el mismo Dios, valiéndose de la criatura sometida a sí mismo, se dirija bajo una apariencia humana a los sentidos humanos, y a los del cuerpo, y a los semejantes que tenemos en los sueños, si no dirige la mente y obra sobre ella con su gracia interior, ningún fruto sacará el hombre de la predicación de la verdad. Pero esto lo hace el Señor separando a los que son objeto de ira de los que lo son de misericordia; se sirve así de una distribución oculta, pero justa, que él bien conoce.

Presta Dios su ayuda con admirables y ocultos modos cuando el pecado que habita en nuestros miembros — pena más bien del pecado— no reina, como nos amonesta el Apóstol, en nuestro cuerpo mortal para satisfacer sus antojos ${ }^{150}$, ni nosotros le presentamos nuestros cuerpos como arma de iniquidad, y entonces el hombre se vuelve, bajo la guía de Dios, a su sana razón, que cesa ya de complacerse en el mal, la mantendrá ahora en el sereno dominio de sí misma y reinará después sin pecado alguno en la paz eterna, habiendo conseguido salud e inmortalidad acabadas.

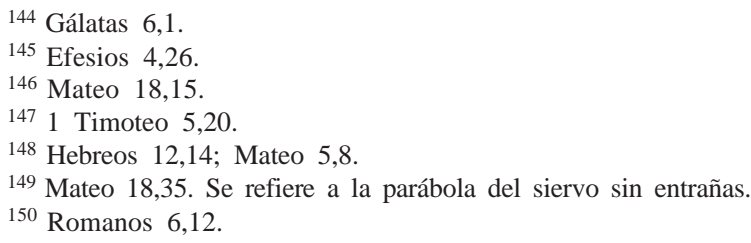




\section{CAPÍTULO VII}

Motivo y OBSTinACiÓn DE CAín EN SU CRIMEN; LA PALABRA DE Dios NO LOGRÓ APARTARLO DE SU CRIMINAL INTENCIÓN

1. ¿Qué le aprovechó a Caín lo que hemos expuesto, según nuestros alcances, cuando le habló Dios por una criatura sometida a sus mandatos, como solía hablar a los primeros padres, usando como buen amigo de una forma apropiada? ¿No llevó a cabo, aun después de haberle amonestado la palabra divina, el crimen concebido de asesinar a su hermano? Había Dios hecho distinción entre los sacrificios de ambos, mirando con agrado los del uno y con displicencia los del otro, cosa que con toda seguridad se conoció por algún signo sensible que lo atestiguaba. Hizo Dios esto porque eran malas las obras de Caín y buenas las de Abel. De lo cual se entristeció mucho Caín y quedó abatido su rostro. Así está escrito: El Señor dijo a Caín: ¿Por qué estás triste y ha empalidecido tu rostro? ¿No es verdad que si ofreces bien y no divides bien, pecas? Cálmate, él se convertirá a ti y tú le dominarás ${ }^{151}$. En esta amonestación de Dios a Caín: ¿No es verdad que si ofreces bien y no divides bien, pecas?, no está claro el sentido, y por eso ha dado lugar a muchos sentidos su oscuridad, cuando intenta cada intérprete de las divinas Escrituras exponerlo en armonía con la regla de fe.

Bien se ofrece el sacrificio cuando se ofrece al único Dios verdadero, a quien solamente se deben sacrificios. Pero no se divide justamente si no se tienen bien en cuenta los lugares, los tiempos, las cosas que se ofrecen, el que lo ofrece, a quién se ofrece, a quiénes se distribuye para alimento lo que se ha ofrecido. Por división hemos de entender aquí el discernimiento: si se ofrece donde no conviene, o lo que no conviene aquí, sino en otra parte; si se ofrece cuando no conviene, o lo que no conviene entonces, sino en otro tiempo; si se ofrece lo que nunca, ni en parte alguna debió ofrecerse; o también cuando el hombre se reserva cosas mejores que las que ofrece a Dios, o cuando se hace partícipe del sacrificio a un profano o a quien no está bien hacerlo. En cuál de estos extremos desagradó Caín a Dios, no puede descubrirse fácilmente. Pero nos dan pie para interpretarlo las palabras del apóstol San Juan hablando de estos hermanos: No como Caín, que estaba de la parte del malo y asesinó a su hermano. $Y$ ¿por qué lo asesinó? Porque sus propias acciones eran malas, y las de su hermano, justas $^{152}$. En lo cual se nos da a entender que no se agradó a Dios en sus obsequios porque dividía mal, dando algo suyo a Dios, pero reservándose a sí mismo para sí.

\footnotetext{
${ }^{151}$ Génesis 4,6-7.

1521 Juan 3,12.
} 
Esto hacen todos los que, siguiendo no la voluntad de Dios, sino la suya, es decir, no viviendo con un corazón puro, sino perverso, ofrecen, sin embargo, a Dios sus presentes, con los que piensan hacérsele propicio, no para que ayude a curar sus depravados deseos, sino a saciarlos. Esto es peculiar de la ciudad terrena: rendir culto a Dios o a los dioses, para con su ayuda salir airosos en las victorias y la paz terrena, no por amor del bien, sino por el ansia de dominar. Los buenos, ciertamente, usan de este mundo para gozar de Dios; los malos, al contrario, quieren usar de Dios para gozar del mundo. Todos ellos creen al menos en su existencia, incluso en su cuidado de las cosas humanas. Porque hay otros peores, que no creen ni en eso.

Conocido por Caín que Dios había mirado con agrado el sacrificio de su hermano y no el suyo, debió, como es lógico, arrepentirse e imitar a su buen hermano, en vez de emularlo con soberbia. Pero se entristeció y su rostro se abatió. Este es el pecado que sobre todo repudia Dios, entristecerse por el bien de otro, sobre todo del hermano. Esto es lo que le reprocha al preguntarle: ¿Por qué estás triste y ha empalidecido tu rostro? Dios veía la envidia hacia su hermano y se lo reprochaba. Para los hombres, a quienes se oculta el corazón del otro, puede ser ambiguo y totalmente incierto si aquella tristeza era fruto de la malicia con que conscientemente había desagradado a Dios, o de la bondad de su hermano, en que se complació Dios al mirar su sacrificio. Pero al explicar Dios el motivo de no haber aceptado su sacrificio, le pone de manifiesto que debía estar descontento justamente contra sí, más que injustamente contra su hermano, ya que era injusto por una división injusta, es decir, por no vivir rectamente, e indigno de la aprobación de su ofrenda, y más injusto aún al odiar sin motivo a su hermano.

2. Cierto, no le despacha sin una recomendación santa, justa y buena; le dice: Cálmate, hacia ti su vuelta, y tú le dominarás. ¿Se refiere a su hermano? En modo alguno. ¿A quién se refiere, pues, sino al pecado? Pues había dicho: Pecaste, y a continuación añadió: Cálmate, hacia ti su vuelta, y tú le dominarás. Puede entenderse que la conversión del pecado debe ser la conversión hacia el hombre, de suerte que se dé cuenta que no debe cargar sobre nadie, sino sobre sí mismo, el pecado. Pues ésta es una medicina de saludable penitencia y una oportuna petición de perdón, de suerte que donde dice: Hacia ti su vuelta, no se entienda "será", sino "sea", a guisa de mandato, no de predicción. Entonces, en efecto, domina uno su pecado cuando no se lo pone ante sí defendiéndolo, sino que lo somete a sí haciendo penitencia; de otra manera será él esclavo de su dominio si le presta cierta protección cuando se comete. 
Por pecado puede entenderse también la concupiscencia carnal, de la que dice el Apóstol: Las apetencias de la carne son contrarias a las del espíritu ${ }^{153}$. Entre los frutos de la carne enumera la envidia, que aguijaba a Caín y le excitaba a la muerte de su hermano; por eso se sobrentiende "será”, esto es, hacia ti su vuelta será, y tú le dominarás. Pues cuando se siente conmovida la misma parte carnal, que llama pecado el Apóstol al decir: No soy yo el que realiza eso, es el pecado que habita en míl ${ }^{154}$ (aun los filósofos llaman vicios a esta parte del espíritu que no debe arrastrar a la mente, sino ser dominada por ella y apartada por la razón de las obras ilícitas), cuando se siente estimulada a obrar depravadamente, si se calma y obedece al Apóstol que dice: No abandonéis vuestros miembros al pecado para servir de instrumento a la iniquidad ${ }^{155}$, se torna, domeñada y vencida, al espíritu, de suerte que queda sometida a la razón.

Esto es lo que le ordenó Dios a quien se abrasaba en las llamas de la envidia contra su hermano y, en vez de imitarle, deseaba hacerle desaparecer. Cálmate, le dice; aparta tu mano del crimen; no reine el pecado en tu cuerpo mortal obedeciendo a sus deseos, ni abandones tus miembros al pecado como instrumento de iniquidad. Hacia ti su vuelta será si, en vez de darle rienda suelta al pecado, lo refrenas con calma. $Y$ tú le dominarás; es decir, cuando no se le permita obrar exteriormente, bajo el poder del espíritu que le va dirigiendo con benevolencia, se acostumbra a no agitarse ni interiormente.

Algo semejante se dijo también en el mismo libro sobre la mujer cuando, después del pecado, preguntando y juzgando Dios, recibieron la sentencia de condenación: el diablo en figura de serpiente, y la mujer y el marido en sí mismos. Habiéndole dicho a ella: Multiplicaré tus trabajos y tus gemidos, y parirás los hijos con dolor, añade a continuación: Te convertirás a tu marido y él te dominará156. Lo que se dijo a Caín sobre el pecado, o sobre la concupiscencia viciosa de la carne, se dice en este lugar sobre la mujer que pecó: donde se debe entender que el varón para regir a la mujer debe asemejarse a la mente que rige la carne. Por eso dice el Apóstol: Amar a su mujer es amarse a sí mismo, y nadie ha odiado nunca a su propio cuerpo ${ }^{157}$.

Debemos sanar estos males como nuestros, no condenarlos como si fueran ajenos. Empero Caín recibió aquel mandato del Señor como prevaricador; y, creciendo la envidia, tendió asechanzas a su hermano y le mató.

\footnotetext{
153 Gálatas 5,17.

154 Romanos 7,17.

155 Romanos 6,13.

156 Génesis 3,16.

157 Efesios 5,28-29.
} 
Tal era el fundador de la ciudad terrena. ¿Cómo significó a los judíos, que dieron muerte a Cristo, pastor de la grey humana, a quien prefiguraba Abel, pastor de rebaños? Todo ello es una alegoría profética, de que me abstengo de hablar ahora; además recuerdo haberlo tratado ya en la obra contra Fausto el maniqueo ${ }^{158}$.

\section{LIBRO XVIII}

\section{CAPÍTULO XLVII}

¿Hubo ANTES DEL CRISTIANISMO, FUERA DEL PUEBLO DE ISRAEL, HOMBRES QUE PERTENECIERAN A LA COMUNIDAD DE LA CIUDAD CELESTE?

Por eso, si algún extranjero, esto es, no nacido de Israel, ni recibido por aquel pueblo en el canon de las Sagradas Letras, de quien se diga que ha profetizado de Cristo, ha llegado o llega a nuestro conocimiento, podemos citarlo nosotros para mayor abundancia. No porque nos sea necesario, ya que podría faltar, sino porque no hay inconveniente en creer que ha habido entre otros pueblos hombres a quienes se ha revelado este misterio y que se han visto impulsados a anunciarlo, ya hayan sido participantes de la misma gracia, ya la hayan conocido adoctrinados por los ángeles malos, de quienes sabemos han confesado a Cristo presente, a quien no reconocían los judíos ${ }^{159}$.

$\mathrm{Ni}$ creo que los mismos judíos pretendan osadamente que nadie ha pertenecido al pueblo de Dios fuera de los israelitas, de donde comenzó la descendencia de Israel, con la reprobación del hermano mayor ${ }^{160}$. En efecto, no hubo otro pueblo que propiamente fuera llamado pueblo de Dios; pero no podemos negar que hubo también en los otros pueblos algunos hombres que pertenecieron, por comunicación no terrena, sino celeste, a los verdaderos israelitas ciudadanos de la patria celeste. Si se atrevieran a negar esto se les convencería fácilmente con el santo y admirable Job, que no era indígena ni prosélito, esto es, advenedizo del pueblo de Israel, sino que procedía de la nación idumea, donde había nacido y donde murió ${ }^{161}$. Y, sin embargo, es tal la alabanza que le tributan las divinas Letras que ningún coetáneo suyo se le puede igualar en santidad y piedad. Sobre el tiempo de su existencia nada encontramos en las Crónicas; sin embargo, atendiendo a

158 Agustín de Hipona, Escritos Antimaniqueos (2º (1986).

159 Véase Mateo 8,29; Marcos 1,24; Lucas 4,34.

160 Se refiere a la preferencia divina por Jacob a pesar de ser menor que su hermano Esaú, ambos hijos de Isaac. Véase Génesis 25,19-37,1.

${ }^{161}$ Véase Job 1,1. 
su libro, que por su valor admitieron los israelitas en el canon, podemos colegir que vivió tres generaciones después de Israel.

No puedo dudar que la divina Providencia intentó por medio de éste hacernos sabedores de que pudieron existir también entre otros pueblos quienes vivieron según Dios y le agradaron, perteneciendo, por tanto, a la Jerusalén espiritual. Cierto que no se debe creer haya sido concedido esto a nadie, sino a quien Dios ha revelado al único mediador entre Dios y los hombres; el hombre Cristo Jesús ${ }^{162}$. Su venida en la carne fue anunciada a los santos antiguos como se nos anunció a nosotros ya su presencia. Así será una única fe en Él mismo la que lleve a Dios a todos los predestinados a la ciudad de Dios, a la casa de Dios, al templo de Dios. Cierto que las profecías de otros acerca de la gracia de Dios por Cristo Jesús pueden tomarse como preparadas por los cristianos. Por eso, si hay quien suscite controversias sobre esto, el argumento más fuerte para convencer a los extraños y hacerlos nuestros, si obran con rectitud, es que se divulguen precisamente las profecías divinas sobre Cristo que están escritas en los libros de los judíos. Es claro que arrancados éstos de sus lares y dispersados por el orbe entero para dar este testimonio, se ha extendido por todas partes la Iglesia de Cristo.

\section{LIBRO XIX}

\section{CAPÍTULO IV}

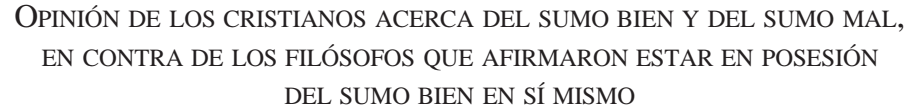

1. ¿Cuál es — se nos preguntará- la respuesta de la ciudad de Dios a todos estos interrogantes, comenzando por los supremos bienes y males? He aquí la respuesta: la vida eterna es el sumo bien; la muerte eterna, el sumo mal. Debemos, pues, vivir ordenadamente, de forma que consigamos aquélla y evitemos ésta. Está escrito: El justo, gracias a su fe, tiene vida ${ }^{163}$. Nosotros, de hecho, no vemos todavía nuestro bien: es, por ello, necesario que lo busquemos mediante la fe. Ni tampoco la rectitud de vida nos viene de nosotros mismos, sino que a los que creen y a los que piden presta su ayuda el dador de nuestra misma fe, la cual, a su vez, nos hace creer en su ayuda.

162 Véase 1 Timoteo 2,5.

163 Habacuc 2,4; Romanos 1,17; Gálatas 3,11; Hebreos 10,38. 
Ellos, en cambio, han pensado que los bienes y males últimos se hallan en esta vida, situando el sumo bien en el cuerpo o en el alma, o en ambos a la vez. Por decirlo más claramente: en el placer, en la virtud o en ambos juntamente; en la tranquilidad, en la virtud o en ambos a la vez; en el placer juntamente con la tranquilidad, en la virtud o en todos a la vez; en los bienes primordiales de la naturaleza, en la virtud o en ambos ${ }^{164}$. Estos filósofos — digo—, con una desvariada pretensión, han querido ser felices en esta tierra, y alcanzar por sí mismos la felicidad. Se burla de ellos la Verdad por las palabras del profeta: Conoce el Señor los pensamientos del hom$b r e^{165}$; o como evidencia el testimonio del apóstol Pablo: El Señor se da cuenta de lo fútiles que son los planes de los listos ${ }^{166}$.

2. ¿Y quién sería capaz de describir todas las miserias de esta vida ni siquiera con ríos de elocuencia? Ya Cicerón, en su libro Sobre el consue$l l^{167}$, con ocasión de la muerte de su hija, se explayó, como pudo, en lamentaciones de esta vida. Pero ¡qué corto se queda! Los llamados bienes primordiales de la naturaleza, ¿cuándo, dónde y cómo pueden de hecho encontrarse aquí abajo sin que estén sujetos a la incertidumbre fluctuante de la casualidad? ¿Qué dolor al acecho del placer, o preocupación al del descanso, no son una continua amenaza para el cuerpo del sabio? La amputación de algún miembro o la parálisis corporal quebrantan la integridad humana; la deformidad, la belleza; los achaques, la salud; la fatiga, la fortaleza; la pesadez o la torpeza, la agilidad. ¿Y cuál de estos males no puede abatirse sobre la carne del sabio? El equilibrio corporal y sus movimientos, cuando son elegantes y armoniosos, se cuentan también entre los bienes primordiales de la naturaleza. Pero ¿qué sucederá si una maligna enfermedad ataca con temblores los miembros? ¿Y si la espina dorsal llegara a curvarse hasta obligar al hombre a poner las manos en el suelo, como si fuera un cuadrúpedo? Toda la elegancia de movimientos y de equilibrio, toda la belleza corporal, ¿¿no queda echada a perder?

¿Y qué diremos de los bienes llamados primarios del espíritu? Dos bienes enumeran estos filósofos en primer lugar en orden a la percepción y a la comprensión de la verdad: el sentido y la inteligencia. ¿Qué restará en el hombre del sentido si — por no citar más que estos dos males— se queda sordo y ciego? ¿ Y adónde irán a parar la razón y la inteligencia, dónde estarían aletargados si el hombre tiene la desgracia de volverse loco por una

${ }^{164}$ Se refiere a las doctrinas de diversas escuelas filosóficas: estoicos, epicúreos y escépticos (académicos).

165 Salmos 94,11.

1661 Corintios 3,20.

${ }^{167}$ Se trata de una obra perdida de Cicerón. 
enfermedad? ¡Cuántas extravagancias no hacen y dicen los frenéticos, ajenas y hasta contrarias muchas veces a sus intenciones y género de vida! Bien pensado, sea que lo imaginemos, sea que lo presenciemos, apenas somos capaces de contener las lágrimas; incluso a veces ni lo somos siquiera. ¿Y qué decir de quienes padecen los asaltos de los demonios? ¿Dónde tienen oculta o sepultada su inteligencia cuando el espíritu maligno utiliza a su gusto el cuerpo y el alma del poseso? ¿Y quién asegura que una tal desgracia no se puede cernir sobre el sabio en este mundo?

Por otra parte, ¿'hasta qué punto es auténtica y total la percepción de la verdad en esta existencia carnal? Porque así leemos en ese libro colmado de verdad, el Libro de la Sabiduría: El cuerpo mortal es lastre del alma y la tienda terrestre abruma la mente pensativa ${ }^{168}$. El impulso o deseo de acción - si es que la expresión traduce fielmente lo que los griegos entienden por ormé- y que ellos tienen entre los bienes básicos de la naturaleza ${ }^{169}$, ¿no es él mismo el origen de los movimientos y actos dignos de lástima que nos horrorizan cuando llega a trastornarse el sentido y embrutecerse la razón?

3. Miremos ahora la virtud, que no cae dentro de los principios de la naturaleza, puesto que se les añade más tarde a través de la educación. Ella reclama para sí el primer puesto entre los bienes del hombre. ¿Y qué hace en este mundo sino una guerra sin tregua a los vicios, no los externos, sino los interiores; no los ajenos, sino más bien los propios de cada persona? Sobre todo, esa virtud que en griego se llama sophrosyné y en latín temperantia (templanza), ¿no lucha contra las pasiones de la carne para ponerles freno, no sea que arrastren hacia alguna desgracia al espíritu que en ellas consiente? Sí, el vicio existe. Oigamos al Apóstol: Las apetencias carnales son contrarias al espíritu; a este vicio se opone la virtud, puesto que, como dice él mismo, las apetencias del espíritu son contrarias a la carne, porque los dos - dice él一 están en conflicto. Resultado: que no hacéis lo que queréis ${ }^{170}$. ¿Y qué queremos nosotros cuando deseamos la consumación del bien supremo sino que las apetencias de la carne no sean contrarias a las del espíritu, y que desaparezca en nosotros el vicio este, contra el cual luchan las apetencias del espíritu? Y como en esta vida no somos capaces de ello, por más que lo intentamos, procuremos, al menos con la ayuda de Dios, no rendir el espíritu, cediendo a las apetencias carnales que están en pugna con él, ni dejarnos arrastrar conscientemente hacia la consumación del pecado.

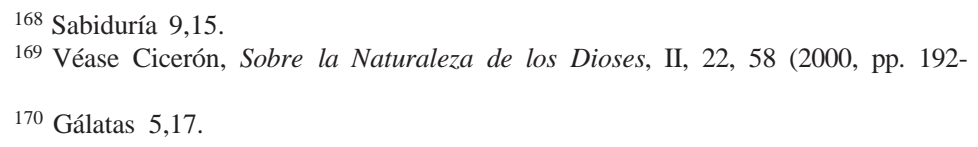


¿Cómo vamos a creer, mientras dure esta guerra interior, que ya hemos alcanzado la felicidad, esa felicidad a la cual anhelamos llegar mediante la victoria? Imposible. ¿Quién es sabio en tan alto grado que ya no tenga absolutamente ninguna lucha con las pasiones?

4. Examinemos ahora la virtud llamada prudencia. ¿'Toda su vigilancia no consiste en discernir los bienes de los males para procurar unos y evitar los otros, de forma que no se deslice ningún error? ¿Y no está con ello evidenciando que nosotros nos hallamos en medio del mal, o que el mal se halla entre nosotros? Ella nos enseña que el mal está en caer en el pecado, consintiendo en las bajas pasiones, $\mathrm{Y}$ el bien en no consentirlas y evitarlo. Con todo, ese mal, al que la prudencia nos enseña a resistir y cuya victoria logramos mediante la templanza, ni una ni otra virtud consigue eliminar de esta vida.

Hablemos de la justicia. Su objeto es dar a cada uno lo suyo (de aquí que en el mismo hombre haya un orden natural justo: el alma se somete a Dios y la carne al alma. Así, alma y carne están a Dios sometidas). Pero ¿̇no está demostrando que aún se encuentra penando en esté trabajo más bien que descansando por haberlo terminado? El alma tanto menos está sometida a Dios, cuanto menos Dios está presente en su pensamiento. Y tanto menos la carne está sometida al alma, cuanto más lucha con sus apetencias contra el espíritu. Y mientras estemos arrastrando esta debilidad, este achaque, esta peste, ¿cómo nos atreveremos a llamarnos liberados si no lo estamos todavía? ¿Cómo nos vamos a llamar bienaventurados con aquella felicidad definitiva?

Veamos también qué nos dice la virtud llamada fortaleza. Participará de toda la sabiduría que se quiera; pero es ella un testimonio irrefutable de los males humanos al sentirse obligada a tolerarlos con la paciencia. No comprendo cómo han tenido desfachatez los estoicos para negar que éstos son verdaderos males, llegando a reconocer que si se agrandasen hasta el punto de no poder o no deber soportarlos el sabio, está obligado a inferirse la muerte a sí mismo y emigrar de esta vida. En hombres como éstos, que pretenden encontrar aquí abajo el sumo bien y conseguir por sí mismos la felicidad, el orgullo ha llegado a un tal grado de aturdimiento, que el sabio según sus cánones, ese sabio que ellos describen con pinceladas de pasmosa vanidad, aunque llegue a quedarse ciego, sordo, mudo, paralítico, atormentado de dolores, cubierto, en fin, de todas las desgracias de este tipo que se puedan decir o imaginar, hasta el punto de sentirse obligado a suicidarse, todavía tienen la desfachatez de llamar bienaventurada a una vida así171.

${ }^{171}$ Los estoicos consideraban que el suicidio es legítimo en circunstancias extremas. Véase Long (1986), p. 206. 
¡Oh qué vida tan feliz que recurre a la muerte para ponerle fin! Si es una vida feliz, continúese viviendo en ella. Pero si por unos males como éstos se pretende escapar de ella, ¿cómo va a ser feliz? ¿Conque son males estos que triunfan sobre un bien que es fortaleza, y no sólo la obligan a rendirse ante ella, sino que hacen disparatar diciendo que una vida así es feliz, pero que hay que huir de ella? ¿Cómo se puede estar tan ciegos para no ver que si es feliz no hay por qué escapar de ella? Pero si se ven obligados a confesar que hay que abandonarla por el peso de sus calamidades, ¿qué razón hay para no reconocer desgraciada esta vida, humillando su orgullosa cerviz? Una pregunta: ¿El célebre Catón ${ }^{172}$ se suicidó por paciencia o más bien por su impaciencia? Nunca habría hecho lo que hizo si hubiera sabido soportar pacientemente la victoria de César. ¿Dónde está su fortaleza? Se rindió, sucumbió, fue derrotada hasta abandonar esta vida, hasta desertar, hasta huir de ella. ¿O es que ya no era feliz? Luego entonces era desgraciada. ¿Y cómo es que no eran males los que convertían la vida en desgraciada y repudiable?

5. Hasta los mismos que confiesan ser males estos que hemos citado, como son los peripatéticos ${ }^{173}$, como son los viejos académicos ${ }^{174}$, de cuya secta Varrón ${ }^{175}$ se muestra defensor, hablan en términos más tolerables. Con todo, caen en un chocante error: el creer que la vida feliz se da en medio de todos esos males, aunque sean tan horrendos que se los debe huir con el suicidio de quien los padece. "Males son —nos dice Varrónlos tormentos y suplicios corporales, y tanto peores cuanto mayores puedan ser. Para liberarte de ellos se hace necesario huir de esta vida.” ¿De qué vida, por favor? "De esta vida — responde-, tiranizada por tamaños males.” Entonces, ¿de verdad es feliz esta vida en medio de esos mismos males que la hacen, como tú dices, repulsiva? ¿O la llamas feliz porque tienes la posibilidad de escapar de esos males con la muerte? ¿Y qué te parece si por una decisión divina te vieras coaccionado a permanecer viviendo, sin posibilidad de morir ni de verte libre de tales sufrimientos? Me imagino que al menos así tú llamarías desdichada a una tal vida. No es precisamente feliz una vida por la posibilidad de abandonarla en seguida. Tú mismo la llamas

172 Catón de Útica (94-46 a.C.) se suicidó, siguiendo principios estoicos, luego de que Julio César derrotara a su aliado Pompeyo.

173 Escuela filosófica, seguidores de Aristóteles.

${ }^{174}$ Seguidores de la filosofía platónica, cuyo nombre se remite a la Academia de Platón. Se distinguen de los nuevos académicos que adoptaron el escepticismo luego de que el platonismo se transformara significativamente.

175 Varrón (116-27 a.C.), intelectual romano de amplio registro a quien Agustín admira profundamente ya que su interpretación de la filosofía platónica, en especial en su aplicación a la naturaleza de la religión romana, parece, según Agustín, anticipar la creencia en un solo Dios. Véase O’Daly (1999), pp. 101-134, y pp. 236-238. 
desgraciada si fuera interminable. Ninguna desgracia, en realidad, nos debe parecer nula por ser breve, ni tampoco — lo que sería aún más absurdo— precisamente por ser breve una desgracia la vamos a llamar felicidad.

¡Qué fuerza tendrán estos males que — según estos filósofos— obligan al hombre, incluso al sabio, a privarse de aquello que le hace hombre! Dicen —y dicen bien — que éste es, por así decirlo, el primer y más agudo grito de la naturaleza humana: mirar por sí mismo y huir instintivamente de la muerte; estimarse a sí mismo hasta el punto de desear con fuerte impulso continuar siendo un viviente y apetecer la unión de su alma con su cuerpo.

¡Qué fuerza tendrán estos males que arrancan el instinto natural que nos lleva a evitar la muerte por todos los medios, con todas nuestras fuerzas, con todos nuestros impulsos! Y lo vence de tal manera que, lo que antes se trataba de evitar, ahora se busca y se apetece, y si una mano ajena no se lo proporciona, el propio hombre se lo infiere a sí mismo.

¡Cuál será la fuerza de estos males, que convierten en homicida a la virtud de la fortaleza!, si es que aún podemos seguir llamando fortaleza a la que está tan rendida ya por estas desgracias, que no solamente se vuelve incapaz de custodiar por la paciencia al hombre, que tiene encomendado, para servirle de guía y protección, como virtud que es, sino que ella misma se siente constreñida a matarlo. Cierto, el sabio debe tolerar pacientemente incluso la muerte, pero venida de otra parte. Ahora bien, según estos filósofos, cuando el mismo sabio se siente en la obligación de procurarse la muerte a sí mismo, es preciso confesar sin rodeos que no se trata únicamente de males: son males insoportables los que le llevan a perpetrarlo.

Una vida que transcurre oprimida bajo el peso de males tan fuertes, tan agudos, o bajo la amenaza de su eventualidad, jamás la llamaríamos feliz si los hombres que así hablan, lo mismo que se rinden ante la desgracia cuando se causa la muerte, vencidos bajo el duro golpe de las calamidades, se dignasen rendirse ante la verdad, vencidos también por razones de peso, en su búsqueda de la vida feliz, y si se quitaran de la cabeza la posibilidad de disfrutar del sumo bien en esta vida mortal: aquí las mismas virtudes, que son —no lo dudamos- el tesoro más preciado y más útil del hombre en este mundo, cuanto más eficaz protección son contra los peligros, las calamidades, los dolores, tanto son más evidentes testimonios de sus desventuras.

Si hablamos de las virtudes verdaderas - y éstas nunca las podrán tener más que aquellos que vivan una vida auténticamente religiosa - no se las dan de poderosas como para librar de toda miseria a los hombres que las poseen (no son mentirosas estas virtudes para proclamar esto); más bien procuran la felicidad de la vida humana —igual que su salvación — mediante la esperanza del siglo futuro, ella que en medio de tantas y tamañas 
calamidades se ve obligada a ser infeliz en este siglo. Porque, ¿cómo va a ser bienaventurada si aún no está a salvo? Por eso, Pablo, el apóstol, al referirse no ya a los hombres sin prudencia, ni paciencia, ni templanza, ni a los malvados, sino a los que llevan una vida verdaderamente religiosa, y con unas virtudes también auténticas, dice: Con esta esperanza nos salvamos. Ahora bien, una esperanza de lo que se ve ya no es esperanza. ¿Quién espera lo que ya ve? En cambio, si esperamos algo que no vemos, estamos aguardando, gracias a la paciencia ${ }^{176}$. Estamos salvados, pues, en esperanza, así como somos bienaventurados en esperanza. Lo mismo la salvación que la bienaventuranza no las poseemos como presentes, sino que las esperamos como futuras, y esto gracias a la paciencia. Estamos en medio de males que debemos tolerar pacientemente hasta que lleguemos a los bienes aquellos donde todo será un gozo inefable, donde nada existirá que debamos ya soportar. Una tal salvación que tendrá lugar en el siglo futuro será precisamente la suprema felicidad. Y como estos filósofos no la ven, se niegan a creer en esta felicidad. Así es como intentan fabricarse aquí una felicidad absolutamente quimérica sirviéndose de una virtud tanto más falseada cuanto más llena de orgullo.

\section{CAPÍTULO V \\ LA VIDA EN SOCIEDAD, AUNQUE PARECE NECESARIA, ESTÁ LLENA DE DIFICULTADES}

El sabio — afirman todos estos filósofos- debe vivir en sociedad. Esta afirmación la suscribimos nosotros con mucha más fuerza que ellos. En efecto, ¿de dónde tomaría su origen, cómo iría desarrollándose y de qué manera conseguiría el fin que se merece esta ciudad de Dios — sobre la que trata esta obra y cuyo libro diecinueve tenemos entre manos — si la vida de los santos no fuese una vida en sociedad? Con todo, ¿quién será capaz de enumerar cuántos y cuán graves son los males de la sociedad humana, sumida en la desdicha de esta vida mortal? ¿Quién podrá calibrarlos suficientemente? Presten oídos a uno de sus cómicos que, con aprobación de todos, expresa el sentir de los hombres: "Me he casado con una mujer: ¡No hay calamidad más grande! Me han nacido los hijos: ¡Nuevas preocupaciones!” ¿Y qué decir de los trapos sucios que el mismo Terencio nos saca a relucir del amor?: "Injurias, celos, enemistades, la guerra; y de nuevo la paz" ${ }^{177}$. ¿ No están llenos los aconteceres humanos de todo esto? ¿No sucede así con demasiada frecuencia incluso en las amistades más limpias de

176 Romanos 8,24-25.

177 Terencio, Eunuco, I, 1,14-18. 
amigos? ¿No es verdad que por todas partes la vida humana está llena de todas estas miserias, de injurias, celos, enemistades, de guerra, de una manera infalible? En cambio, el bien de la paz es problemático, puesto que ignoramos el corazón de aquellos con quienes la quisiéramos tener, y si hoy podemos conocerlo, mañana nos serán desconocidas sus intimidades.

¿Quiénes suelen o, al menos, deberían ser más amigos entre sí que los que conviven en una misma casa? Y, sin embargo, ¿quién está allí seguro cuando con frecuencia se dan allí tamañas contrariedades debidas a ocultos manejos, contrariedades tanto más amargas cuanto más dulce había sido la paz que se creía verdadera, pero que se simulaba con refinada astucia? Hasta el corazón del hombre penetra esta herida, haciéndole lanzar un gemido de dolor como el de Cicerón: "No hay insidias más ladinas que las que se cubren bajo la apariencia del deber o con el título de alguna obligación amistosa. El adversario que lo es a plena luz, con un poco de cuidado lo puede esquivar. Pero esta plaga oculta, intestina, doméstica, no solamente está ahí, sino que te echa el lazo antes de que puedas descubrirla o investigarla"178. Esta es la razón por la que aquella consigna, incluso divina, los enemigos del hombre son los de su casa ${ }^{179}$, la oímos con gran dolor de nuestro corazón. Un hombre, aunque tuviere tal fortaleza que pudiera soportar con serenidad los ocultos manejos que contra él trama una simulada amistad, o aunque estuviera tan alerta que fuera capaz de esquivarlos con acertadas decisiones, es imposible, si él personalmente es bueno, que no sufra cruelmente por la maldad de estos hombres pérfidos cuando comprueba que eran unos perversos, tanto si lo han sido siempre y se han estado fingiendo honrados, como si se han hecho unos malvados después de haber sido buenos. Si el propio hogar, refugio universal en medio de todos estos males del humano linaje, no ofrece seguridad, ¿qué será la sociedad estatal, que cuanto más ensancha sus dominios, tanto más rebosan sus tribunales de pleitos civiles o criminales, y que aunque a veces cesen las insurrecciones y las guerras civiles, con sus turbulencias - y más frecuentemente aún - con su sangre, de cuyas eventualidades pueden verse libres de vez en cuando las ciudades, pero de su peligro jamás?

\section{CAPÍTULO VI}

ERROR DE LOS JUICIOS HUMANOS CUANDO LA VERDAD PERMANECE OCULTA

¿Qué diremos de las sentencias emitidas por los hombres sobre los hombres que no pueden faltar en la vida ciudadana, por muy en paz que

178 Cicerón, In Verrem Actio 2, I, 15 (1990).

179 Mateo 10,36. 
transcurra? ¿Qué idea nos hacemos de ellas? ¡Qué tristes, qué deplorables son! Emiten veredictos quienes no son capaces de ver la conciencia de los sometidos a juicio. Y, como consecuencia, para averiguar la verdad más de una vez se ven en la necesidad de someter a tortura a testigos inocentes en una causa que nada les concierne. ¿Y no es peor todavía cuando, por una causa propia, alguien es torturado, y por averiguar si es culpable se aplican tormentos, pagando el inocente unas ciertísimas penas por un delito incierto, no por descubrirse que lo ha cometido, sino por ignorarse que no lo ha cometido? He aquí que con frecuencia la ignorancia del juez es la desgracia del inocente. Pero lo que es aún más intolerable, lo que clama al cielo, lo que es digno de regarse, si fuera posible, con ríos de lágrimas, es que el juez torture a un acusado para no matar por ignorancia a un inocente, sucediendo, por la calamitosa ignorancia, que manda ajusticiar al torturado e inocente precisamente por haberlo hecho torturar en evitación de una muerte siendo inocente.

Si uno, en efecto, siguiendo la sabiduría de estos filósofos eligiera marcharse de esta vida antes que seguir soportando por más tiempo los tormentos, está confesando haber cometido lo que no había cometido. Una vez condenado y ajusticiado, todavía el juez ignora si acaba de matar a un inocente o a un culpable al someterlo a tortura para evitar la muerte de un inocente por ignorancia. Lo ha torturado para saber si era inocente, y lo ha matado porque no sabía si lo era. En tales tinieblas de la vida social, un juez con sabiduría ¿¿se sentará en el tribunal o no se sentará? Se sentará, naturalmente. Se lo impone y le arrastra al desempeño de este cargo la sociedad humana, a la que él tiene como un crimen abandonar. ¡Y, en cambio, no tiene como un crimen el torturar a testigos inocentes en causas ajenas! ¡ $\mathrm{Ni}$ es un crimen para él castigar a aquellos que en el curso del interrogatorio, vencidos por la violencia de las torturas, y confesando falsamente su culpabilidad, ya eran inocentes cuando fueron torturados! ¡Ni tampoco el que algunos, aunque no sean condenados a muerte, mueren la mayoría de las veces en las torturas o a consecuencia de ellas! ¡Ni tiene como un crimen el que a veces los mismos acusadores, deseando quizá ser útiles a la sociedad humana, por no permitir la impunidad de los delitos, y a pesar de que dicen la verdad, no les es posible probar sus acusaciones por haber testigos falsos que se obstinan en la mentira, y por endurecerse el mismo reo en no confesar a pesar de los tormentos, son condenados estos acusadores por un juez que desconoce la verdad! Males como éstos, tan numerosos y de tanto volumen, no son tenidos como pecados para él. No realiza estos desmanes un juez lleno de sabiduría por el afán de hacer daño; es efecto de su ignorancia invencible, es efecto de su obligación de dar sentencia, a pesar 
de su ignorancia. ¡Pero se lo exige la humana sociedad! ¡He aquí, realmente, la miseria del hombre, bien que no la malicia del sabio! Y a él, que por una inevitable ignorancia, y por una sentencia obligatoria, tortura a inocentes, castiga a quienes no tienen culpa, ¿̇le parecerá poco el no sentirse reo, si es que no llega incluso a sentirse dichoso? ¡Cuánto más sensato y digno de un hombre puesto en tal necesidad sería reconocer la propia miseria y, aborreciéndola en sí mismo, clamar a Dios si le queda algún sentimiento de piedad: Sácame, Señor, de mis aprietos! ${ }^{180}$.

\section{CAPÍTULO VII}

LA DIVERSIDAD DE LENGUAS, FUENTE DE DIVISIÓN SOCIAL. MISERIA DE LAS GUERRAS, INCLUSO DE LAS LLAMADAS JUSTAS

Después de la ciudad, de la urbe, viene el orbe de la tierra, el llamado tercer grado de la sociedad humana: el hogar, la urbe y el orbe, en una progresión ascendente. Aquí ocurre como con las aguas: cuanto más abundantes, tanto más peligrosas.

Tenemos en primer lugar la diversidad de lengua, causa de distanciamiento de un hombre con otro hombre. Imaginemos, por ejemplo, a dos hombres, ignorantes cada uno de la lengua del otro, que se encuentran y no pasan de largo, sino que deben permanecer juntos por alguna razón: con más facilidad convivirían dos animales, mudos como son, de especies diferentes, que estos dos hombres. Al no poderse comunicar sus sentimientos, debido a la sola diversidad de idioma, de nada les sirve a estos hombres ser tan semejantes por naturaleza. Hasta tal punto esto es así, que más a gusto está un hombre con su perro que con otro hombre extranjero.

Pero se han tomado medidas — se replicará - para que el Estado dominador imponga no sólo su yugo, sino también su propia lengua a las naciones sometidas, mediante tratados de paz, de manera que no falten, es más, haya abundancia de intérpretes. Sí, es cierto. Pero, todo esto ¿̇e ha conseguido? ¿A precio de cuántas y cuán enormes guerras, de cuán descomunales catástrofes humanas, de cuánta sangre derramada? Y cuando todo esto ha pasado ya, todavía no ha terminado la desdicha de esas mismas calamidades. Porque, aunque no han faltado ni faltan naciones enemigas extranjeras contra las que siempre se ha estado en guerra —y se está-, no obstante, la extensión misma del imperio ha engendrado guerras de peor clase: guerras de partidos, es decir, guerras civiles, que destrozan la humanidad de la manera más triste, tanto cuando rompen las hostilidades, para

180 Salmos 25,17. 
terminar de una vez, como cuando viven en el temor de una nueva insurrección. Si yo pretendiera hacer una descripción del número y variedad de las catástrofes que tienen su origen en estas calamidades, de lo penoso y horrendo de sus inevitables secuelas, aunque sería incapaz de lograrlo como se merece, ¿hasta dónde nos llevaría este interminable discurso?

Pero el hombre instruido en la sabiduría — nos replicarán ellossólo declarará guerras justas. ¡Como si no debiera deplorar — si recuerda que es hombre- mucho más el hecho de tener que reconocer la existencia misma de guerras justas! Porque de no ser justas nunca debería emprenderlas, y, por tanto, para el hombre sabio no existiría guerra alguna. Es la injusticia del enemigo la que obliga al hombre formado en la sabiduría a declarar las guerras justas. Esta injusticia es la que el hombre debe deplorar por ser injusticia del hombre, aunque no diera origen necesariamente a una guerra. Males como éstos, tan enormes, tan horrendos, tan salvajes, cualquiera que los considere con dolor debe reconocer que son una desgracia. Pero el que llegue a sufrirlos o pensarlos sin sentir dolor en su alma, y sigue creyéndose feliz, está en una desgracia mucho mayor: ha perdido hasta el sentimiento humano.

\section{CAPÍTULO VIII \\ INSEGURIDAD DE LA AMISTAD ENTRE LOS BUENOS, DADOS LOS TEMIBLES E INEVITABLES PELIGROS DE ESTA VIDA}

¡Cuidado no nos acontezca esa ignorancia rayana en la demencia, no infrecuente, por cierto, en esta nuestra mísera condición, que llega a tomar un enemigo por amigo y viceversa! ¿Qué consuelo nos queda en una sociedad humana como ésta, plagada de errores y de penalidades, sino la lealtad no fingida, y el mutuo afecto de los buenos y auténticos amigos? Pero cuantos más tengamos repartidos por doquier, tanto más se agranda nuestro temor de que les suceda alguno de tantos males como se amontonan por este mundo. No nos causa preocupación solamente el que puedan ser víctimas del hambre, la guerra, la enfermedad o la cautividad, y de que puestos en esta servidumbre tengan que sufrir males que ni somos capaces de imaginar. Lo que nos preocupa con una amargura infinitamente mayor es que puedan caer en la infidelidad, la malicia o la perversión. Y cuando algo así nos sobreviene (y ocurre tanto más frecuentemente cuanto más numerosos y dispersos están los amigos) y la noticia llega hasta nosotros, ¿quién se dará cuenta del fuego que abrasa nuestro corazón, sino quien lo siente en su propio ser? Preferiríamos enterarnos de su muerte, aunque también esta 
noticia nos causaría dolor. Si la vida de tales amigos era para nosotros un verdadero placer, por el consuelo de su amistad, ¿cómo va a ser posible que su muerte no nos cause tristeza alguna? Y si alguien llega a prohibir esta tristeza, prohíba también, si le es posible, las amistosas charlas, ponga su veto, destruya el afecto entre amigos, rompa con despiadado estupor los lazos espirituales de todo afecto humano, o bien dé normas para usar de todo ello de manera que el corazón no quede inundado por ninguna de sus dulzuras. Y si esto resulta de todo punto imposible, ¿cómo no nos va a ser amarga la muerte de quien nos es dulce la vida? De aquí arranca esa especie de lamento de todo corazón que aún se conserve humano, esa llaga, esa úlcera que para cerrarse necesita atenciones consoladoras. Decir que se restañan estas heridas tanto más pronto y sin dificultad cuanto mejor dispuesto esté el ánimo, no equivale a decir que la herida no existe.

Es verdad que la muerte de los seres más queridos, especialmente de aquellos cuyos servicios son más indispensables a la sociedad, nos causa aflicción, unas veces más mitigada y otras más cruel. Pero en lo que se refiere a los que amamos con afecto, preferiríamos verlos o saberlos muertos antes que caídos en la infidelidad o en la corrupción de sus costumbres; en otras palabras, antes que muertos en el alma.

Llena está la tierra de este enorme cúmulo de desgracias. De ahí el texto de la Escritura: ¿No es, acaso, una tentación la vida del hombre sobre la tierra? ${ }^{181}$ Esta misma razón hace exclamar al Señor: $¡ A y$ del mundo por los escándalos! ${ }^{182} \mathrm{Y}$ de nuevo: Al crecer —dice—la maldad se enfriará la caridad en la mayoría ${ }^{183}$. De aquí que debemos felicitar a nuestros amigos ya muertos, y si bien su muerte nos causa tristeza, ella misma nos da un consuelo más seguro: de hecho para ellos se han terminado los males que destrozan o corrompen, o al menos exponen a ambos peligros incluso a los hombres de bien.

\section{CAPÍTULO X}

RECOMPENSA QUE AGUARDA A LOS SANTOS POR LA SUPERACIÓN DE LAS PRUEBAS DE ESTA VIDA

Ni siquiera los santos, fieles adoradores del único, verdadero y supremo Dios, están inmunes de las falacias diabólicas y sus tentaciones de todas clases. De hecho, en este valle de miserias, en estos días llenos de

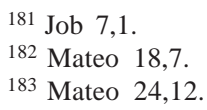


maldad, no está de más vivir en esta alarma: nos sirve para mantenernos en una búsqueda anhelante y cada vez más ardiente de aquella seguridad, donde la paz llega a su plenitud y se mantiene lejos de todo riesgo. Allí se darán cita los dones naturales, es decir, aquellas prendas con que el autor de toda naturaleza ha obsequiado a la nuestra. Se trata no sólo de dones excelentes, sino perdurables; no sólo de dones propios del espíritu, llevados a la perfección por la sabiduría, sino también del cuerpo, que se transformará con la resurrección. Allí brillarán las virtudes, pero no en pugna con vicio o mal alguno: disfrutarán, como recompensa de su victoria, de una paz eterna, que ningún adversario será capaz de turbar.

He aquí la bienaventuranza final, he aquí la perfección suprema que no se extinguirá jamás. Aquí abajo nos llamamos, en realidad, felices cuando disfrutamos de paz, esa paz recortada que es posible encontrar en una vida honrada. Pero si comparamos tal felicidad con la bienaventuranza que llamamos final, se queda en una mera desventura. Cuando nosotros, hombres mortales, disfrutamos de esa paz que es posible encontrar aquí, si nuestra vida es ordenada, la virtud se sirve rectamente de sus bienes. Y cuando esta paz nos falta, también la virtud sabe usar para bien incluso los males que el hombre arrastra. Pero solamente existe verdadera virtud cuando, junto con todos los bienes de que ella hace recto uso y los actos realizados en el recto uso de bienes y males, sabe referirse a sí misma hacia aquel fin donde disfrutaremos de una tal paz, que mejor y más profunda no será posible.

\section{CAPÍTULO XI}

\section{BEATITUD DE LA PAZ ETERNA, EN LA QUE LOS SANTOS ENCUENTRAN SU FIN, LA VERDADERA PERFECCIÓN}

Después de lo dicho podemos concluir que nuestros supremos bienes consisten en la paz, de igual modo que lo habíamos afirmado de la vida eterna. En efecto, muy señaladamente en uno de los sagrados salmos, y refiriéndose a esta misma ciudad de Dios —objeto de esta nuestra exposición tan trabajosa-, se dice: Glorifica al Señor, Jerusalén; alaba a tu Dios, Sión; que ha reforzado los cerrojos de puertas, y ha bendecido a tus hijos dentro de ti; ha puesto paz en tus fronteras ${ }^{184}$. Cuando se hayan asegurado los cerrojos de sus puertas, ya nadie más entrará en ella, y nadie de ella saldrá ya. Por sus fronteras debemos entender aquí esa paz suprema que ahora intentamos explicar. Ya el misterioso nombre de la ciudad, Jerusa-

184 Salmos $147,12-14$ 
lén, citado más arriba, significa "visión de paz". Pero dado que la palabra paz se utiliza con frecuencia incluso mezclada entre las realidades perecederas, en las que ciertamente no se halla la vida eterna, para designar el fin de esta ciudad, en el que consistirá su bien supremo, hemos preferido la expresión "vida eterna” más bien que "paz".

Dice el Apóstol a propósito del citado fin: Ahora, en cambio, emancipados del pecado, y entrados al servicio de Dios, tenéis como fruto la santificación y como fin la vida eterna ${ }^{185}$. Pero como por otra parte los que no gozan de una cierta familiaridad con las Sagradas Escrituras pueden entender la expresión "vida eterna" aplicada a los malvados, sea en el sentido de algunos filósofos, que defienden la inmortalidad del alma; sea incluso como la cree nuestra fe, que a los impíos les asigna interminables castigos - de hecho no podrán sufrir eternos castigos más que viviendo eternamente-; he ahí por qué el fin de esta ciudad, en el que consistirá el bien supremo, lo debemos llamar "la paz de la vida eterna", o bien "la vida eterna en paz”. Así será más fácil su comprensión para todos.

Tan estimable es la paz, que incluso en las realidades terrenas y transitorias normalmente nada suena con un nombre más deleitoso, nada atrae con fuerza más irresistible; nada, en fin, mejor se puede descubrir. Voy a hablar con cierto detenimiento de este tesoro que es la paz. Estoy seguro de que no me haré pesado a los lectores: lo pide el fin de esta ciudad de la que estamos tratando; lo pide aquello mismo que a todos nos es tan grato: la propia dulcedumbre de la paz.

\title{
CAPÍTULO XII
}

\author{
LAS MISMAS CRUELDADES DE LA GUERRA Y TODAS LAS \\ PREOCUPACIONES HUMANAS DESEAN VIVAMENTE LLEGAR A LA PAZ FINAL. \\ TODO SER LA APETECE POR NATURALEZA
}

1. Cualquiera que observe un poco las realidades humanas y nuestra común naturaleza reconocerá conmigo que no existe quien no ame la alegría, así como tampoco quien se niegue a vivir en paz. Incluso aquellos mismos que buscan la guerra no pretenden otra cosa que vencer. Por tanto, lo que ansían es llegar a una paz cubierta de gloria. ¿Qué otra cosa es, en efecto, la victoria más que la sumisión de fuerzas contrarias? Logrado esto, tiene lugar la paz. Con miras a la paz se emprenden las guerras, incluso por aquellos que se dedican a la estrategia bélica, mediante las órdenes y el combate. Está, pues, claro que la paz es el fin deseado de la guerra. Todo hombre,

185 Romanos 6,22. 
incluso en el torbellino de la guerra, ansía la paz, así como nadie trabajando por la paz busca la guerra. Y los que buscan perturbar la paz en que viven no tienen odio a la paz; simplemente la desean cambiar a su capricho. No buscan suprimir la paz; lo que quieren es tenerla como a ellos les gusta. Y, en definitiva, aunque por una insurrección rompan con otros, nunca conseguirán el fin pretendido, a menos que mantengan la paz —una paz, al menos en apariencia - entre los propios miembros de la conspiración o conjura.

Los mismos bandoleros, cuando intentan atacar la paz ajena con más seguridad y más violencia, procuran tenerla entre sus compinches. Y en el supuesto de que haya uno que sobresalga en fuerza, pero tan desconfiado de sus camaradas que no quiera saber nada con ninguno, obrando por su cuenta, tendiendo emboscadas y derribando a cuantos puede, despojando a sus víctimas, sean atacados o asesinados, con todo mantiene sin falta al menos una sombra de paz con aquellos que no puede eliminar y a quienes quiere ocultar sus fechorías. En casa procura, con su mujer y sus hijos y demás que allí convivan, mantenerse pacífico. Naturalmente, satisfecho de que al menor signo se le obedezca sin rechistar. Y si no, monta en cólera, riñe, castiga, y, si fuera necesario, restablece por el terror la paz de su hogar. Es consciente de que no puede haber paz si no están sometidos a una cabeza — que en su casa es él - todos los componentes de la sociedad familiar. Supongamos que le brindaran el dominio sobre una multitud, una ciudad o una nación, por ejemplo, con una sumisión como la que quería imponer en su propia casa: entonces ya no andaría escondido en guaridas como un ladrón, sino que se pondría sobre un pedestal como rey a plena luz, sólo que su perversión y su codicia seguirían intactas.

Es un hecho: todos desean vivir en paz con los suyos, aunque quieran imponer su propia voluntad. Incluso a quienes declaran la guerra intentan apoderarse de ellos, si fuera posible, y una vez sometidos imponerles sus propias leyes de paz.

2. Imaginemos un hombre con los rasgos que le atribuye el canto de la poesía ficticia de las fábulas. Quizá por su insociable salvajismo nos apetecería, en lugar de hombre, llamarle semihombre. Su reino estaba reducido a la espantosa soledad de una caverna. Tan conocida era su maldad, que no tenía otro nombre sino el de Malo — que es lo que en griego significa kakos, su nombre propio ${ }^{186}$ - Sin esposa con quien intercambiar unas blandas palabras, sin hijo alguno con quien entretenerse durante su infancia y educarlo en su adolescencia. Sin disfrutar de una amistosa conversa-

${ }^{186}$ La historia de Hércules y Caco se encuentra en Virgilio, Eneida, 8, 190-312 (2000, pp. 236-240); y en Ovidio, Fastos, I, 545-587 (2001, pp. 44-46). 
ción, ni siquiera la de su padre, Vulcano ${ }^{187}$, cuya felicidad hubiera podido aventajar al menos en esto: en no haber engendrado él otro monstruo semejante. Jamás daba nada a nadie; al contrario, robaba lo que le venía en gana a quien podía y cuando podía. Con todo, en su antro solitario, cuyo suelo, según la descripción, estaba siempre caliente de la sangre de alguna matanza reciente, nada ansiaba sino la paz, una paz en la que nadie le molestase, ni turbase su reposo con violencias o amenazas. Deseaba, en fin, estar en paz con su propio cuerpo, y cuanto más lo estaba, tanto mejor se sentía. En efecto, daba órdenes a sus miembros obedientes; y cuando era necesario apaciguar cuanto antes su naturaleza mortal, sublevada contra él por la indigencia, y provocando la rebeldía del hambre para apartar y excluir el alma del cuerpo, robaba, mataba, devoraba. Salvaje y feroz como era, cuidaba, sin embargo — de una manera salvaje y feroz-, de tener en paz su vida y su salud. Si la misma paz que él procuraba tener en su caverna y en sí mismo la hubiera querido tener también con los demás, nunca le hubiéramos llamado malo, ni monstruo, ni semihombre. Y si la deformidad de su cuerpo y las horrendas llamas que vomitaba alejaban de su compañía aterrorizados a los hombres, quizá su crueldad no partía tanto de una pasión por hacer daño, cuanto de una necesidad de sobrevivir.

Pero este hombre no existió en realidad, o —más verosímil aún— no existió con los rasgos que nos lo ha dibujado la huera poesía. Porque si Caco no hubiera sido acusado excesivamente, los elogios a Hércules se quedarían cortos. De hecho un hombre de tal calaña - mejor, un semihombre, ya lo he dicho - no lo creemos real, como tantas y tantas fantasías de los poetas. Las mismas fieras, en su mayor crueldad —él también participó de su fiereza: se le llamó, además, semifiera—, custodian la propia especie con una cierta paz: conviven juntas, se fecundan, paren, cuidan y nutren a sus cachorros, siendo en su mayoría insociables y hurañas. No, por cierto, como las ovejas, los ciervos, las palomas, los estorninos, las abejas, sino más bien como los leones, las zorras, las lechuzas. ¿Qué tigre no arrulla, manso, a sus cachorros, y los acaricia blandamente, olvidado de su fiereza? ¿Qué milano, por muy solitario que vuele sobre su presa, no fecunda a su pareja, y entreteje el nido, incuba los huevos y alimenta a sus polluelos, y conserva, como si fuera para con su propia madre, la hogareña convivencia con toda la paz que le es posible? ¡Cuánto más el hombre se siente de algún modo impulsado por las leyes de su naturaleza a formar sociedad con los demás hombres y a vivir en paz con todos ellos en lo que esté de su mano! ¡Si hasta los mismos malvados emprenden la guerra en busca de la paz para los suyos! Si les fuera posible, someterían bajo su dominio a todos los

${ }^{187}$ Dios romano del fuego. 
hombres para que todo y todos estuvieran al servicio de uno sólo. ¿Qué les mueve sino el que acepten estar en paz con él, sea por amor, sea por temor? ¡He aquí cómo la soberbia trata de ser una perversa imitación de Dios! Detesta que bajo su dominio se establezca una igualdad común, y, en cambio, trata de imponer su propia dominación a sus iguales en el puesto de Dios. Detesta la justa paz de Dios, y ama la inicua paz impuesta por ella misma. Pero lo que no puede lograr de manera alguna es dejar de amar la paz de una forma u otra. No existe vicio tan contrario a la naturaleza que borre incluso sus últimos vestigios.

3. De ahí que la paz de los malvados, al lado de la de los justos, no merece el nombre de paz a los ojos de quien sabe anteponer la rectitud a la perversión y el orden al caos. A pesar de todo, el mismo caos necesariamente ha de estar en paz con alguna de las partes en las que se halla, o con las que consta. De otro modo dejaría por completo de existir.

Supongamos a un hombre suspendido cabeza abajo. La situación de su cuerpo y el orden de sus miembros son caóticos: lo que la naturaleza exige estar encima está debajo, y lo que exige estar debajo está encima. Este desorden ha trastornado la paz corporal y, como consecuencia, causa un dolor. A pesar de todo, el alma está en paz con su cuerpo y se preocupa de su salud; por eso hay un hombre que sufre. Y si, acosada por los sufrimientos, el alma se alejara, si los miembros mantienen su trabazón durante algún tiempo es gracias a una paz que existe entre sus partes, y por eso todavía alguien continúa suspendido. Y este cuerpo terreno, si tiende hacia la tierra y está como retenido por un vínculo de suspensión, es porque aspira al orden que pide su propia paz y está reclamando, por la voz de su pesantez, el lugar de su reposo. Una vez exánime y despojado de todo sentido, no se apartará ya de la paz según el orden de su naturaleza, sea porque ya la posee, sea porque hacia ella tiende. De hecho, si se le aplican al cadáver ciertas sustancias y un tratamiento que impidan la corrupción y la disolución de su integridad, una cierta paz conserva unidas las partes unas a otras, haciendo posible la colocación del cuerpo íntegro en un lugar de la tierra apropiado y, por ende, pacífico. Pero si no se le aplica ningún tratamiento, abandonándolo al proceso natural, tiene lugar una como revolución de vapores hostiles, desagradables a nuestros sentidos — no otra cosa es el hedor percibido - hasta que se reúna con los elementos del mundo, integrándose en las leyes de su paz, poco a poco, partícula por partícula.

Nada hay que pueda sustraerse de las leyes del supremo Creador y ordenador, que regula la paz del universo. En efecto, aunque del cadáver de un animal grande nazcan diminutos animalillos, todos estos seres minúsculos, en virtud de la misma ley del Creador, obedecen en sus propios y 
diminutos principios vitales a la paz de su salud. Y aunque las carnes de unos animales sean devoradas por otros, siempre encuentran las mismas leyes, extendidas por doquier, con el fin de armonizar en la paz los elementos convenientes para la conservación de cada especie, sea cualquiera el sitio a donde vayan a parar, o los elementos a que llegue a unirse, o las sustancias en que se cambie o se transforme.

\section{CAPÍTULO XIII}

LA PAZ UNIVERSAL: NO PUEDE SUSTRAERSE A LA LEY DE LA NATURALEZA EN MEDIO DE CUALESQUIERA PERTURBACIONES; BAJO EL JUSTO JUEZ SE LLEGA SIEMPRE A LOGRAR, EN VIRTUD DEL ORDEN NATURAL, LO QUE SE HA MERECIDO POR LA VOLUNTAD

1. La paz del cuerpo es el orden armonioso de sus partes. La paz del alma irracional es la ordenada quietud de sus apetencias. La paz del alma racional es el acuerdo ordenado entre pensamiento y acción. La paz entre el alma y el cuerpo es el orden de la vida y la salud en el ser viviente. La paz del hombre mortal con Dios es la obediencia bien ordenada según la fe bajo la ley eterna. La paz entre los hombres es la concordia bien ordenada. La paz doméstica es la concordia bien ordenada en el mandar y en el obedecer de los que conviven juntos. La paz de una ciudad es la concordia bien ordenada en el gobierno y en la obediencia de sus ciudadanos. La paz de la ciudad celeste es la sociedad perfectamente ordenada y perfectamente armoniosa en el gozar de Dios y en el mutuo gozo en Dios. La paz de todas las cosas es la tranquilidad del orden. Y el orden es la distribución de los seres iguales y diversos, asignándole a cada uno su lugar.

Los desgraciados, por tanto, que en cuanto tales ciertamente no están en paz, no gozan de la tranquilidad del orden, sin perturbación alguna. Sin embargo, como su desgracia es merecida y justa, tampoco pueden estar en ella misma fuera de un orden. No unidos, por supuesto, a los bienaventurados, sino separados de ellos, pero siempre por la ley del orden. Estos, en cuanto están exentos de turbación, se ajustan a la situación en que están con una cierta adaptación. Por eso en ellos queda un resto de la tranquilidad del orden, un resto de paz. Y si es verdad que por gozar de una relativa seguridad se disminuyen sus sufrimientos, en realidad son desgraciados, puesto que no se encuentran donde ya deben estar seguros y sin padecimiento. Pero todavía serían más desgraciados si no están en paz con la misma ley que regula todo el orden natural. Cuando sufren tiene lugar la perturbación de la paz en la parte afectada por el sufrimiento. En cambio, 
todavía subsiste la paz en la parte que no atenaza el sufrimiento, ni sufre alteración su integridad. Porque así como se da una vida sin dolor, y el dolor no puede darse sin vida alguna, de idéntica forma puede existir una paz sin guerra, pero jamás una guerra sin alguna paz. No en cuanto a la guerra en sí, sino desde el punto de vista de la planificación de quienes la llevan a cabo por uno u otro bando, todo lo cual tiene una existencia como naturalezas que son. Y éstas no podrían existir en modo alguno si no permanecieran bajo alguna paz, llámese como quiera.

2. Consiguientemente existen naturalezas en las que no hay mal alguno, e incluso en las que no lo puede haber. En cambio, una naturaleza en la que esté ausente todo bien no puede darse. Y, por tanto, ni siquiera la naturaleza del diablo, en cuanto tal naturaleza, es un mal. Ha sido su perversidad la que lo ha hecho malo. De hecho, él no se mantuvo en la verdad ${ }^{188}$, pero no pudo escapar al juicio de la verdad. No se mantuvo en la tranquilidad del orden, pero tampoco pudo huir del poder del ordenador. El bien divino que él participa por naturaleza no lo sustrae a la justicia de Dios, la cual le pone orden en el castigo. Y Dios aquí no persigue al bien por Él creado, sino al mal por el diablo cometido. Ni tampoco le retira a la naturaleza todo lo que le dio, sino que le priva de algo, y algo le deja para que haya quien sufra por lo que le falta. El mismo dolor es un testimonio del bien sustraído y del bien que aún permanece. De otro modo, el bien que permanece nunca podría dolerse del bien que le falta. La maldad del que peca es tanto más refinada cuanto más se complace en el daño cometido contra la justicia. El que sufre una tortura, si con ella no consigue bien alguno, se duele del detrimento causado a su salud. Y como la justicia y la salud son bienes ambos, y de la pérdida del bien hay que dolerse, más bien que alegrarse (a no ser que tenga lugar una compensación mejor; por ejemplo, mejor es la justicia del espíritu que la salud del cuerpo), se deduce, por consiguiente, que es mucho más ordenado el dolor del malvado en el suplicio que su gozo en el delito cometido. La alegría de la deserción del bien es testimonio en el pecado de una malvada voluntad, así como el dolor del bien perdido es testimonio en el castigo de una naturaleza buena. El que sufre la paz perdida de su naturaleza, sufre en virtud de los restos de paz que le hacen posible el sentir como algo deseable la misma naturaleza. En el supremo castigo justamente sucede que los inicuos e impíos deploren en sus tormentos los daños ocasionados a los bienes de su naturaleza, conscientes de que sus privaciones vienen de Dios con la mayor justicia, por ser despreciado en su amabilísima generosidad.

188 Juan 8,44. 
Dios, el autor sapientísimo, y el justísimo regulador de todo ser, ha puesto a este mortal género humano como el más bello ornato de toda la tierra. Él ha otorgado al hombre determinados bienes apropiados para esta vida: la paz temporal a la medida de la vida mortal en su mismo bienestar y seguridad, así como en la vida social con sus semejantes, y, además, todo aquello que es necesario para la protección o la recuperación de esta paz, como es todo lo que de una manera adecuada y conveniente está al alcance de nuestros sentidos: la luz, la oscuridad, el aire puro, las aguas limpias y cuanto nos sirve para alimentar, cubrir, cuidar y adornar nuestro cuerpo. Pero todo ello con una condición justísima: que todo el mortal que haga recto uso de tales bienes, de acuerdo con la paz de los mortales, recibirá bienes más abundantes y mejores, a saber: la paz misma de la inmortalidad, con una gloria y un honor de acuerdo con ella en la vida eterna con el fin de gozar de Dios y del prójimo en Dios. En cambio, el que abuse de tales bienes no recibirá aquéllos, y éstos los perderá.

\section{CAPÍTULO XIV}

EL ORDEN Y LA LEY, TANTO CELESTE COMO TERRESTRE. ESTA INCLUSO CUANDO

ALGUIEN DOMINA, VELA POR LA SOCIEDAD HUMANA, Y, AL HACERLO, A ELLA SE OBEDECE

Toda utilización de las realidades temporales es con vistas al logro de la paz terrena en la ciudad terrena. En la celeste, en cambio, mira al logro de la paz eterna. Supongamos que fuésemos animales irracionales; nada apeteceríamos fuera de una ordenada armonía de las partes del cuerpo y la calma de las apetencias. Nada, pues, fuera de la tranquilidad de la carne y la abundancia de placeres, de manera que la paz del cuerpo favoreciese a la paz del alma. Porque si falta la paz del cuerpo se pone impedimento a la del alma, carente de razón, al no poder lograr la calma de los apetitos. Ambos, principio vital y cuerpo, se favorecen mutuamente la paz que tienen entre sí, es decir, la del orden de la vida y de la buena salud. Los animales demuestran amor a la paz de su cuerpo cuando esquivan el dolor, y a la de su alma cuando buscan el placer de sus apetitos para saciar su necesidad. Del mismo modo, huyendo de la muerte evidencian claramente cuánto aman la paz que mantiene unidos alma y cuerpo.

Pero en lo que al hombre se refiere, como está dotado de un alma racional, todo aquello que de común tiene con las bestias lo somete a la paz del alma racional, y de esta forma primero percibe algo con su inteligencia, y 
luego obra en consecuencia con ello, de manera que haya un orden armónico entre pensamiento y acción, que es lo que hemos llamado paz del alma racional. Para lograrlo debe aspirar a sentirse libre del impedimento del dolor, de la turbación del deseo y de la corrupción de la muerte. Así, cuando haya conocido algo conveniente, sabrá adaptar su vida y su conducta a este conocimiento.

Pero dada la limitación de la inteligencia humana, para evitar que en su misma investigación de la verdad caiga en algún error detestable, el hombre necesita que Dios le enseñe. De esta forma, al acatar su enseñanza estará en lo cierto, y con su ayuda se sentirá libre. Pero como todavía está en lejana peregrinación hacia el Señor todo el tiempo que dure su ser corporal y perecedero, le guía la fe, no la visión ${ }^{189}$. Por eso, toda paz corporal o espiritual, o la mutua paz entre alma y cuerpo es con vistas a aquella paz que el hombre durante su mortalidad tiene con el Dios inmortal para tener así la obediencia bien ordenada según la fe bajo la ley eterna.

Dios, como maestro, le ha enseñado al hombre dos preceptos fundamentales: el amor a Dios y al prójimo. En ellos ha encontrado el hombre tres objetos de amor: Dios, él mismo y el prójimo. Quien a Dios ama no se equivoca en el amor a sí mismo. Por consiguiente, debe procurar que también su prójimo ame a Dios, ese prójimo a quien se le manda amar como a sí mismo; por ejemplo, la esposa, los hijos, los de su casa, todos los hombres que le sea posible. Pero también él debe ser ayudado a esto mismo por el prójimo si alguna vez lo necesita. Así es como logrará la paz — en cuanto le sea posible - con todos los hombres, esa paz que consiste en la concordia bien ordenada de los hombres. Y el orden de esta paz consiste primero en no hacer mal a nadie y luego en ayudar a todo el que sea posible.

La primera responsabilidad que pesa sobre el hombre es con relación a los suyos, que es a quienes tiene más propicia y fácil ocasión de cuidar, en virtud del orden natural o de la misma vida social humana. Dice a este respecto el Apóstol: Quien no mira por los suyos, en particular por los de su casa, ha renegado de la fe y es peor que un descreído ${ }^{190}$. De aquí nace también la paz del hogar, es decir, la armonía ordenada en el mandar y en el obedecer de los que conviven juntos. En efecto, mandan aquellos que se preocupan; por ejemplo, el marido a la mujer, los padres a sus hijos, los dueños a sus criados. Y obedecen los que son objeto de esa preocupación; por ejemplo, las mujeres a sus maridos, los hijos a sus padres, los criados a sus amos. Pero en casa del justo, cuya vida es según la fe, y que todavía es

\footnotetext{
1892 Corintios 5,6-7.

1901 Timoteo 5,8.
} 
lejano peregrino hacia aquella ciudad celeste, hasta los que mandan están al servicio de quienes, según las apariencias, son mandados. Y no les mandan por afán de dominio, sino por su obligación de mirar por ellos; no por orgullo de sobresalir, sino por un servicio lleno de bondad.

\section{CAPÍTULO XV}

LA LIBERTAD NATURAL Y LA ESCLAVITUD. ESTA TIENE COMO PRIMERA CAUSA EL PECADO. EL HACE QUE UN HOMBRE DE MALA VOLUNTAD, AUNQUE NO PERTENEZCA A OTRO HOMBRE, SEA ESCLAVO DE SUS PROPIAS PASIONES

Este es el orden que exige la naturaleza; así ha creado Dios al hombre: Que tenga dominio - le dice- sobre los peces del mar, sobre las aves del cielo y sobre todos los reptiles de la tierra ${ }^{191}$. Al ser racional, creado a su imagen, no lo ha querido hacer dueño más que de los seres irracionales. No ha querido que el hombre dominara al hombre, sino el hombre a la bestia. Los primeros justos fueron puestos más bien como pastores de rebaños que como regidores de hombres. Trataba Dios de insinuarnos, incluso por este medio, cuáles son las exigencias del orden natural, y cuáles las exigencias de la sanción del pecado. La situación de esclavitud —ahora se comprende- es una justa imposición hecha al pecador. De hecho no encontramos en pasaje alguno de la Escritura el término esclavo antes de que Noé, varón justo, lo empleara para castigar el pecado de su hijo ${ }^{192}$. Ha sido, pues, el pecado quien ha acarreado este concepto, no la naturaleza.

El origen latino de la palabra esclavo (servus) parece ser que radica en los que por derecho de guerra podían ser ajusticiados, pero los vencedores a veces les "conservaban" la vida, haciéndoles siervos (servi), llamados así de servare (conservar). Todo lo cual no sucede tampoco sin la culpa del pecado. En efecto, aunque se luche en una guerra justa, el adversario lucha cometiendo pecado. Y toda victoria, conseguida incluso por los malos, humilla a los vencidos, según un divino designio, corrigiendo o castigando los pecados. Testigo de ello es aquel hombre de Dios, Daniel, que en su estado de cautiverio confesaba a Dios sus pecados y los de su pueblo, declarando con piadoso dolor que ésta era la causa de su cautividad ${ }^{193}$.

La causa primera de la esclavitud es, pues, el pecado, que hace someterse un hombre a otro hombre con un vínculo de condición social. Y todo ello no sucede sin un designio de Dios, en quien no existe la injusticia,

\footnotetext{
191 Génesis 1,26.

192 Génesis 9,25.

193 Daniel 9,3-19.
} 
y que sabe distribuir castigos diferentes, según la culpa de cada reo. Así afirma el soberano Señor: Quien comete pecado es esclavo del pecado ${ }^{194}$. Por esto sucede que muchos hombres religiosos son esclavos de amos inicuos, quienes, sin embargo, no son libres: Pues cuando uno se deja vencer por algo, queda hecho su esclavo ${ }^{195}$. Por cierto que trae más cuenta servir a un hombre que a la pasión, la cual, por no citar más que una: la pasión de dominio, destroza con su misma tiránica dominación el corazón de los mortales. Por otra parte, en este orden de la paz, según el cual unos están sometidos a otros, así como la humildad favorece a los que sirven, así también la soberbia perjudica a los que ejercen dominio. Pero por naturaleza, tal como Dios creó en un principio al hombre, nadie es esclavo de otro hombre o del pecado.

A pesar de todo, esta misma esclavitud, fruto del pecado, está regulada por una ley que le hace conservar el orden natural y le impide perturbarlo. Porque si no se hubiera quebrantado esta ley, no habría lugar a castigo alguno de esclavitud. Por esta razón el Apóstol recomienda incluso a los esclavos que se sometan de corazón a sus amos, y les sirvan de buena gana ${ }^{196}$. De este modo, si no pueden emanciparse de sus dueños, convertirán su esclavitud en una, por así decir, libertad, sirviendo con afectuosa fidelidad, en lugar de servir bajo un temor hipócrita, hasta que pase la injusticia y se aniquile toda soberanía y todo humano poder, y Dios lo sea todo para todos ${ }^{197}$.

\section{CAPÍTULO XVI}

\section{EL JUSTO DERECHO DE DOMINIO}

Nuestros santos patriarcas, aunque tuvieron esclavos, administraban la paz doméstica distinguiendo la condición de los hijos de la de los esclavos en lo referente a los bienes temporales. Pero en lo relativo al culto a Dios, en quien estriba la esperanza de los bienes eternos, miraban con la misma solicitud por todos los miembros de su casa. Todo ello es tan de acuerdo con el orden natural que el nombre de paterfamilias (padre de familia) surgió de esta realidad, y se ha extendido tanto que incluso los tiranos se precian de tal nombre. Y los que son auténticos padres de familia cuidan de que todos los de su casa, como si se tratara de hijos, honren y

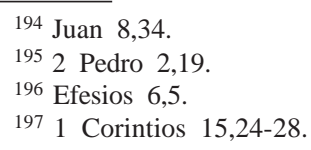


estén a bien con Dios, vivamente anhelantes de llegar a la casa celestial, donde ya no habrá necesidad de mandar a los mortales, puesto que no será necesario cuidar de ellos, felices ya en aquella inmortalidad. Y en la espera de llegar allá, más les toca soportar a los padres por mandar, que a los esclavos por servir.

Cuando alguien en la casa se opone a la paz doméstica por su desobediencia, se le corrige de palabra, con azotes o con otro género de castigo justo y lícito, según las atribuciones que le da la sociedad humana y para la utilidad del corregido, a fin de integrarlo de nuevo en la paz de la que se había separado. Porque igual que no se presta ningún beneficio a quien se ayuda a perder un bien mayor que el que ya tenía, así tampoco está exento de culpa quien por omisión deja caer a otro en un mal más grave. La inocencia lleva consigo la obligación no sólo de no causar daño a alguien, sino de impedir el pecado y de corregir el ya cometido. De esta manera el castigado se corregirá en cabeza propia, o los demás escarmentarán en la ajena.

La familia debe ser el principio y la parte mínima de la ciudad. Y como todo principio hace referencia a un fin en su género, y toda parte se refiere a la integridad del todo por ella participado, se desprende evidentemente que la paz doméstica se ordena a la paz ciudadana, es decir, que la bien ordenada armonía de quienes conviven juntos en el mandar y en el obedecer mira a la bien ordenada armonía de los ciudadanos en el mandar y obedecer. Según esto, el padre de familia debe tomar de las leyes de la ciudad aquellos preceptos que gobiernen su casa en armonía con la paz ciudadana.

\section{CAPÍTULO XVII}

\section{ORIGEN DE LA PAZ Y DE LA DISCORDIA ENTRE LA SOCIEDAD CELESTIAL}

$$
\text { Y LA CIUDAD TERRENA }
$$

La familia humana que no vive de la fe busca la paz terrena en los bienes y ventajas de esta vida temporal. En cambio, aquella cuya vida está regulada por la fe está a la espera de los bienes eternos prometidos para el futuro. Utiliza las realidades temporales de esta tierra como quien está en patria ajena. Pone cuidado en no ser atrapada por ellas ni desviada de su punto de mira, Dios, y procura apoyarse en ellas para soportar y nunca agravar el peso de este cuerpo corruptible, que es lastre del alma ${ }^{198}$. He aquí que el uso de las cosas indispensables para esta vida mortal es común a estas dos clases de hombres y de familias. Lo que es totalmente diverso es

198 Sabiduría 9,15. 
el fin que cada uno se propone en tal uso. Así, la ciudad terrena, que no vive según la fe, aspira a la paz terrena, y la armonía bien ordenada del mando y la obediencia de sus ciudadanos la hace estribar en un equilibrio de las voluntades humanas con respecto a los asuntos propios de la vida mortal.

La ciudad celeste, por el contrario, o mejor la parte de ella que todavía está como desterrada en esta vida mortal, y que vive según la fe, tiene también necesidad de esta paz hasta que pasen las realidades caducas que la necesitan. Y como tal, en medio de la ciudad terrena va pasando su vida de exilio en una especie de cautiverio, habiendo recibido la promesa de la redención y, como prenda, el don del Espíritu. No duda en obedecer a las leyes de la ciudad terrena, promulgadas para la buena administración y mantenimiento de esta vida transitoria. Y dado que ella es patrimonio común a ambas ciudades, se mantendrá así la armonía mutua en lo que a esta vida mortal se refiere.

Pero la ciudad terrena ha tenido sus propios sabios, rechazados por la enseñanza divina, que, según sus teorías, o tal vez engañados por los demonios, han creído como obligación el tener propicios, respecto de los asuntos humanos, a multitud de dioses. Cada realidad humana, según ellos, caería, en cierto modo, bajo la responsabilidad de un dios: a uno le correspondería el cuerpo, a otro el alma; y dentro del mismo cuerpo, a uno la cabeza, a otro la nuca, y así cada miembro a otros tantos dioses. Y en el alma algo semejante: a uno el ingenio, a otro la ciencia, a otro la ira, a otro la concupiscencia. Y en el campo de las realidades concernientes a la vida, a uno le asignan el ganado, a otro el trigo, a otro el vino, a otro el aceite, a otro los bosques, a otro el dinero, a otro la navegación, a otro las guerras y las victorias, a otros los casamientos, a otro el parto y la fecundidad, y así sucesivamente. $\mathrm{Y}$ dado que la ciudad celestial sólo reconoce a un Dios como digno de adoración y de rendirle el culto que en griego se llama latreia, y cree con religiosa fidelidad que es exclusivo de Dios, el hecho es que no puede tener comunes las leyes religiosas con la ciudad terrena. De aquí surgió un desacuerdo inevitable. Comenzó a ser un peso para quienes pensaban de otra forma, y tuvo que soportar sus iras, sus rencores, la violencia de sus persecuciones. Sólo en alguna ocasión logró contener la animosidad de sus adversarios por el temor al gran número de sus adeptos y siempre con el divino auxilio.

Esta ciudad celeste, durante el tiempo de su destierro en este mundo, convoca a ciudadanos de todas las razas y lenguas, reclutando con ellos una sociedad en el exilio, sin preocuparse de su diversidad de costumbres, 
leyes o estructuras que ellos tengan para conquistar o mantener la paz terrena. Nada les suprime, nada les destruye. Más aún, conserva y favorece todo aquello que, diverso en los diferentes países, se ordena al único y común fin de la paz en la tierra. Sólo pone una condición: que no se pongan obstáculos a la religión por la que — - según la enseñanza recibida- debe ser honrado el único y supremo Dios verdadero.

En esta su vida como extranjera, la ciudad celestial se sirve también de la paz terrena y protege, e incluso desea - hasta donde lo permita la piedad y la religión-, el entendimiento de las voluntades humanas en el campo de las realidades transitorias de esta vida. Ella ordena la paz terrena a la celestial, la única paz que al menos para el ser racional debe ser reconocida como tal y merecer tal nombre, es decir, la convivencia que en perfecto orden y armonía goza de Dios y de la mutua compañía en Dios.

Cuando haya llegado a este su destino ya no vivirá una vida mortal, sino absoluta y ciertamente vital. Su cuerpo no será ya un cuerpo animal, que por sufrir corrupción es lastre del alma, sino un cuerpo espiritual, libre de toda necesidad, sumiso por completo a la voluntad. En su caminar según la fe por país extranjero tiene ya esta paz, y guiada por la fe vive la justicia cuando todas sus acciones para con Dios y el prójimo las ordena al logro de aquella paz, ya que la vida ciudadana es, por supuesto, una vida social.

\section{CAPÍTULO XXI}

\section{SEGÚN LAS DEFINICIONES QUE ESCIPIÓN DA EN EL DIÁLOGO DE CICERÓN, ¿HA EXISTIDO ALGUNA VEZ EL ESTADO ROMANO?}

1. Llega ya el momento de decir con la mayor concisión y claridad posibles lo que he prometido aclarar en el segundo libro de esta obra, a saber: que en las definiciones formuladas por Escipión en la obra ciceroniana titulada La República jamás ha existido un Estado romano ${ }^{199}$. Define él con brevedad el Estado (res publica) como una "empresa del pueblo". Si esta definición es verdadera, nunca ha existido un Estado romano, porque nunca ha sido empresa del pueblo, definición que él eligió para el Estado. Define el pueblo, efectivamente, como una multitud reunida en sociedad por la adopción en común acuerdo de un derecho y por la comunión de intereses. Qué entienda él por adopción de un derecho, lo va explicando a través de la discusión, y demuestra así cómo no puede gobernarse un Estado sin

${ }^{199}$ Véase Libro II, capítulo 21, incluido en esta selección. 
justicia. Porque donde no hay justicia no puede haber tampoco un derecho. Lo que se hace según derecho se hace con justicia. Pero lo que se hace injustamente es imposible que sea según derecho. Y no podemos llamar derecho ni tenerlo como tal a las injustas determinaciones de los hombres, siendo así que estos mismos hombres sostienen que el derecho dimana de la fuente de la justicia, y desmienten como espuria la afirmación que suelen repetir algunos espíritus torcidos, que es derecho lo que reporta utilidad al más fuerte. Así que donde no hay verdadera justicia no puede haber una multitud reunida en sociedad por el acuerdo sobre un derecho, es decir, no puede haber un pueblo, según la citada definición de Escipión, o, si preferimos, de Cicerón. Y si no hay pueblo, tampoco habrá empresa del pueblo, sino una multitud cualquiera que no merece el nombre de pueblo. Ahora bien, si e1 Estado (res publica) es la empresa del pueblo, y no hay pueblo que no esté asociado en aceptación de un derecho, y tampoco hay derecho donde no existe justicia alguna, la conclusión inevitable es que donde no hay justicia no hay Estado.

La justicia, por otra parte, es la virtud que da a cada uno lo suyo. Ahora bien, ¿qué justicia humana es aquella que arranca al hombre del Dios verdadero para hacerlo esclavo de los impuros demonios? ¿Es esto darle a cada uno lo suyo? ¿O es que robarle la hacienda a quien la había comprado, dándosela a otro que no tenía ningún derecho sobre ella, lo llamaremos injusto, y si uno se sustrae a sí mismo de la autoridad de Dios, que lo ha creado, y se hace esclavo de los espíritus malignos, a esto lo llamaremos justo?

2. Mucho se discute, es cierto, con gran agudeza y acaloramiento, en contra de la injusticia y a favor de la justicia, en la misma obra La república. En un principio se toma partido por la injusticia en contra de la justicia, argumentando que si no es a base de injusticias no es posible mantener ni llevar adelante el Estado. El principio que quedaba sólidamente establecido era la injusticia de que unos hombres estuvieran al servicio de otros que ejercían dominio sobre ellos. Ahora bien, si una ciudad dominadora, capital de un vasto Estado, no adopta esta injusticia, no puede ejercer sus dominios sobre las provincias.

A estos argumentos respondieron los partidarios de la justicia: tal servidumbre es justa puesto que a esos mismos hombres les reporta una ventaja, y es para su mayor bien cuando se hace como es debido, es decir, cuando a los indeseables se les arrebata la posibilidad de cometer delitos. Se logra con ello que estén mejor bajo el dominio de otro, que antes con su 
independencia. Se añade a continuación, para reforzar el argumento, un ejemplo ilustre tomado como de la naturaleza, y se dice: “¿Por qué Dios domina al hombre, el alma al cuerpo, la razón a la pasión y demás partes viciosas del espíritu?” Este ejemplo muestra bien a las claras que la sumisión es útil para algunos y, naturalmente; el sometimiento a Dios es útil para todos. El alma sometida a Dios es con pleno derecho dueña del cuerpo, y en el alma misma la razón sometida a Dios, el Señor, con pleno derecho es dueña de la pasión y demás vicios. Por lo tanto, cuando el hombre no se somete a Dios, ¿qué justicia queda en él? Si el alma no está sometida a Dios, por ningún derecho puede ella dominar el cuerpo ni la razón los vicios. Y si en un hombre así está ausente toda justicia, por supuesto lo estará también en un grupo integrado por tales individuos. Luego en este caso no existe aceptación de un derecho que constituye como pueblo a una multitud de hombres, cuya empresa común la llamamos Estado.

¿Y qué decir de los intereses, por cuya comunión se asocia este grupo de hombres para llamarse pueblo, según la definición formulada? Aunque bien considerado, ni siquiera interés alguno se puede seguir a quienes viven en la impiedad, como sucede a todo el que no se hace servidor de Dios y, en cambio, sirve a los demonios, seres tanto más impíos cuanto más empeño ponen en reclamar sacrificios para sí mismos como a dioses, siendo como son los espíritus más inmundos. No obstante, me parece suficiente lo que acabamos de decir sobre la aceptación de un derecho, de donde se desprende, según esta definición, que no hay pueblo cuya empresa pueda llamarse pública si no hay justicia.

Podrán replicar que el Estado romano no se entregó a los espíritus impuros, sino a los dioses buenos y santos. ¿Habrá que repetir de nuevo una y otra vez los mismos argumentos que ya hemos expuesto suficientemente, incluso hasta la saciedad? Si alguien ha llegado en su lectura hasta aquí, pasando por libros anteriores, ¿podrá quedar todavía con la menor sombra de duda de que los romanos han adorado a dioses perversos e inmundos, a menos que se trate de un estúpido en grado superlativo, o de un intrigante sinvergüenza? Pero, en fin, voy a callarme sobre la casta de esos seres a quienes ellos ofrecían sacrificios; que hable la ley del Dios verdadero, donde leemos: El que ofrezca sacrificios a los dioses, fuera del Señor, será exterminado ${ }^{200}$. No ha permitido el sacrificio, pues, ni a los dioses buenos ni a los malos quien da este precepto con una amenaza de tal gravedad.

200 Éxodo 22,19. 


\section{CAPÍTULO XXIII}

\section{$[\ldots]$}

Conclusión, pues: cuando falta la justicia de que hemos hablado, en virtud de la cual el único y supremo Dios, según la ley de su gracia, da órdenes a la ciudad que le obedece de no ofrecer sacrificios más que a Él sólo, y como consecuencia que en todos los hombres, miembros de esta ciudad y obedientes a Dios, el alma sea fiel dueña del cuerpo, y la razón de los vicios, según un orden legítimo; y que lo mismo que un solo justo, así también una comunidad y un pueblo de justos vivan de la fe, fe que se pone en práctica por el amor, un amor por el que el hombre ama a Dios, como debe ser amado, y al prójimo como a sí mismo; cuando, pues, falta esta justicia no hay una comunidad de hombres asociados por la adopción en común acuerdo de un derecho y una comunión de intereses. Si esto falta — dando como verdadera la anterior definición de pueblo—-, ciertamente no existe un pueblo. Y, por tanto, ni tampoco Estado (res publica), ya que no hay empresa común del pueblo donde no hay pueblo.

\section{CAPÍTULO XXIV}

SIGUIENDO OTRA DEFINICIÓN, PUEDEN CON TODO DERECHO LLAMARSE PUEBLO Y ESTADO NO SÓLO ROMA, SINO TAMBIÉN OTROS REINOS

Pero si la realidad "pueblo" la definimos de otra manera, por ejemplo: "Es el conjunto multitudinario de seres racionales asociados en virtud de una participación concorde en unos intereses comunes”, entonces, lógicamente, para saber qué clase de pueblo es debemos mirar qué intereses tiene. No obstante, sean cualesquiera sus intereses, si se trata de un conjunto no de bestias, sino de seres racionales, y está asociado en virtud de la participación armoniosa de los bienes que le interesan, se puede llamar pueblo con todo derecho. Y se tratará de un pueblo tanto mejor cuanto su concordia sea sobre intereses más nobles, y tanto peor cuanto más bajos sean, éstos. De acuerdo con esta definición, que es nuestra, el pueblo romano es verdadero pueblo, y su empresa, una empresa pública, un Estado, sin lugar a dudas. La historia es testigo de los intereses que este pueblo tuvo en sus primeros tiempos y cuáles en etapas posteriores; de la conducta que le arrastró a rebeliones cruentas, y de aquí a las guerras sociales y civiles, rompiendo y corrompiendo esta concordia, que es —digámoslo así- la salud de un pueblo. De todo esto ya hemos hablado abundantemente en los 
libros precedentes. No por eso voy a negar que Roma sea un pueblo, o que su empresa sea un Estado, con tal que se mantenga de algún modo el conjunto multitudinario de seres racionales asociados en virtud de la participación en unos intereses comunes.

Lo que acabo de decir respecto de este pueblo y de este Estado entiéndase, asimismo, afirmado y sentido de Atenas y demás Estados griegos, de Egipto, de aquel antiguo imperio asirio, Babilonia, cuando sus Estados eran dueños de grandes o pequeños imperios y, en general, de cualquier otro Estado de la tierra. La ciudad de los impíos carece de la auténtica justicia, en general, rebelde como es a la autoridad de Dios, que le manda no ofrecer sacrificios más que a Él y, consiguientemente, al alma ser dueña del cuerpo y a la razón de los vicios de una manera justa y constante.

\section{CAPÍTULO XXV}

NO PUEDEN EXISTIR VIRTUDES VERDADERAS DONDE FALTA

LA VERDADERA RELIGIÓN

Por más laudable que parezca el dominio del alma sobre el cuerpo y de la razón sobre las pasiones, si tanto el alma como la razón no están sometidas a Dios, tal, como el mismo Dios lo mandó, no es recto en modo alguno el dominio que tienen sobre el cuerpo y las pasiones. ¿De qué cuerpo, en efecto, puede ser dueña un alma, o de qué pasiones, si desconoce al verdadero Dios y no se somete a su dominio, sino que se prostituye a los más viciosos y corruptores demonios? Por eso, hasta las virtudes que estos hombres tienen la impresión de haber adquirido, mediante las cuales mantienen a raya el cuerpo y las pasiones, con vista al logro o conservación de cualesquiera valores, pero sin referirlas a Dios, incluso ellas mismas son vicios más bien que virtudes. Y aunque algunos las tengan por verdaderas y nobles virtudes, consideradas en sí mismas y no ejercitadas con alguna otra finalidad, incluso entonces están infatuadas, son soberbias, $y$, por tanto, no se las puede considerar como virtudes, sino como vicios. Pues así como lo que hace vivir a la carne no procede de ella, sino que es algo superior, así también lo que hace al hombre vivir feliz no procede del hombre, sino que está por encima del hombre. Y dígase lo mismo no sólo del hombre, sino también de cualquier otra potestad o virtud celeste. 


\section{CAPÍTULO XXVI}

La paz de los pueblos alejados de Dios. De ella SE SiRVE EL PUeblo DE DIOS DURANTE SU EXILIO EN ESTE MUNDO PARA FOMENTAR LA RELIGIÓN

Así como el alma es el principio vital de la carne, así también Dios es la vida bienaventurada del hombre. De ello dicen las sagradas Letras de los hebreos: Dichoso el pueblo cuyo Dios es el Señor ${ }^{201}$. Desgraciado, por tanto, el pueblo alejado de este Dios. Con todo, también él ama la paz, una cierta paz que le es propia y que no hay por qué despreciar. Cierto que no disfrutará de esta paz al final, porque no la ha utilizado debidamente antes de ese final. Y a nosotros nos interesa también que durante el tiempo de esta vida disfrute de esta paz, puesto que mientras están mezcladas ambas ciudades, también nos favorece la paz de Babilonia. De esta ciudad se libera el pueblo de Dios por la fe, es verdad, pero teniendo que convivir con ella durante el tiempo de su destierro. De aquí que el mismo Apóstol encomendase a la Iglesia orar por los reyes y autoridades, añadiendo estas palabras: Para que tengamos una vida tranquila y sosegada, con la mayor piedad y amor posibles ${ }^{202}$. Ya el profeta Jeremías, junto con el anuncio al antiguo pueblo de Dios de su futura cautividad, y con el mandato divino de que fuesen dócilmente a Babilonia, ofreciendo sus mismos padecimientos como un servicio a Dios, les aconsejó también que orasen por la ciudad, y les dijo: Porque su paz será la vuestra ${ }^{203}$. Una paz todavía temporal, por supuesto, común a buenos y malos.

\section{CAPÍTULO XXVII}

LA PAZ DE LOS SERVIDORES DE DIOS, CUYA PERFECTA TRANQUILIDAD NO ES POSIBLE LOGRARLA EN ESTA VIDA TEMPORAL

Pero esa otra paz peculiar nuestra la tenemos ya aquí al lado de Dios por la fe, y en la eternidad la tendremos a su lado por visión directa. Bien es verdad que tanto la paz común a unos y otros, como la nuestra propia, podemos considerarla más bien como un alivio de nuestra desgracia que como un disfrute de la felicidad. De hecho, nuestra misma santificación (iustitia), aunque sea verdadera porque dice relación al último y verdadero bien, sin embargo, es tan limitada en esta vida que más bien consiste en la

\footnotetext{
201 Salmos 144,15.

2021 Timoteo 2,2.

203 Jeremías 29,7.
} 
remisión de los pecados que en la perfección de las virtudes. Testigo de ello es la oración de toda la ciudad de Dios, exiliada en estas tierras. Así clama por boca de todos sus miembros: Perdónanos nuestras deudas, así como nosotros perdonamos a nuestros deudores ${ }^{204}$. Y la eficacia de tal oración no se aplica a quienes, por no tener obras, tienen muerta su $\mathrm{fe}^{205}$, sino a aquellos cuya fe se pone en práctica por el amor ${ }^{206}$. La razón, por más que esté sometida a Dios, al hallarse bajo esta condición mortal y en este cuerpo corruptible — que es lastre del alma ${ }^{207}$ — no puede dominar perfectamente las malas inclinaciones. De ahí la necesidad para los justos de tal oración. En efecto, aunque llegue a dominar estas malas inclinaciones, no es capaz de hacerlo sin una lucha contra ellas. Y, naturalmente, en esta mansión de miseria, incluso al más valiente luchador, y al que ya tiene dominio de sus enemigos, después de vencerlos y someterlos, algún pecado se les desliza, si no ya fácilmente en sus obras, sí al menos en las palabras, tan resbaladizas, o en los pensamientos, tan difíciles de controlar. Y, por tanto, mientras se está tratando de dominar nuestros viciosos instintos, no se disfruta de plena paz, puesto que los que ofrecen resistencia necesitan peligrosos combates hasta su rendición; por otra parte, el triunfo sobre los ya rendidos no ofrece una tranquilidad segura, sino que es necesario mantenerlos a raya con estrecha vigilancia. En medio de todas estas tentaciones, a las que alude brevemente la divina Palabra en estos términos: ¿No es cierto que la vida del hombre sobre la tierra es una tentación? ${ }^{208}$, ¿quién tendrá la presunción de vivir sin necesidad de decirle a Dios: Perdónanos nuestras deudas, más que un hombre infatuado? No se trata aquí de un gran hombre; es más bien un presumido, un jactancioso, al cual, con plena equidad, rechaza quien ofrece gracia a los humildes. A este respecto está escrito: Dios se enfrenta con los arrogantes, pero concede gracia a los humildes ${ }^{209}$.

En esta vida, por tanto, la santidad (iustitia) de cada uno consiste en que el hombre esté sometido a Dios con docilidad, el cuerpo lo esté al alma y las inclinaciones viciosas a la razón, incluso cuando éstas se rebelan, sea sometiéndolas, sea oponiéndoles resistencia; consiste, además, en pedirle al mismo Dios la gracia para hacer méritos, el perdón de las faltas, así como en darle gracias por los bienes recibidos.

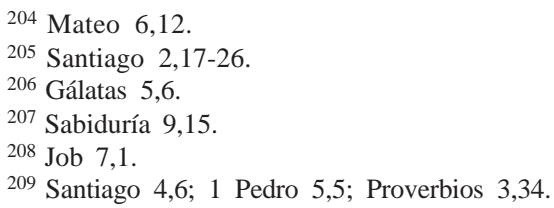


Pero en aquella paz final, hacia donde debe tender y por la que hay que conseguir esta santidad, nuestra naturaleza, recuperada su integridad por la inmortalidad y la incorrupción, no tendrá inclinaciones viciosas; nada se enfrentará contra nadie, ni por parte de sí mismo ni de algún otro; y no será necesario que la razón tenga sometida bajo su control a las inclinaciones viciosas — que habrán ya desaparecido_- Dios mandará al hombre, el alma al cuerpo, y al obedecer será tanta la suavidad y la facilidad, cuanta será la felicidad en el gozo de vivir y de reinar. Y todo esto será eterno en todos y cada uno, y habrá certeza de su eternidad. La paz de esta felicidad, o la felicidad de esta paz, constituirá el supremo bien.

\section{CAPÍTULO XXVIII}

\section{DESTINO FINAL DE LOS IMPÍOS DESPUÉS DE SU MUERTE}

Por el contrario, a los que no pertenecen a esta ciudad de Dios les aguarda una eterna desgracia, también llamada muerte segunda ${ }^{210}$, porque allí ni se puede decir que el alma esté viva — separada, como está, de la vida de Dios-, ni se puede decir que lo esté el cuerpo, atenazado por eternos tormentos. He ahí por qué esta segunda muerte será más atroz que la primera, puesto que no podrá terminar con la muerte.

Ahora bien, lo mismo que la desgracia se opone a la felicidad y la muerte a la vida, así parece oponerse la guerra a la paz. Por eso, lo mismo que hemos hablado y ensalzado la paz como el bien supremo, podemos preguntarnos cuál será, cómo habremos de entender que será la guerra como el mal supremo. Quien se haga esta pregunta que ponga atención a lo que la guerra tiene de dañino y pernicioso. Descubrirá que no es más que el hallarse las cosas en oposición, en pugna las unas contra las otras. ¿Qué guerra más encarnizada y amarga se puede uno imaginar que la voluntad luchando contra las pasiones, y las pasiones contra la voluntad, de tal forma que ninguno ponga fin con su victoria a tales hostilidades, y al mismo tiempo la violencia del dolor luchando contra la naturaleza corporal, sin que jamás se rinda ninguno de los contendientes? En este mundo, cuando tal conflicto tiene lugar, o vence el dolor poniendo fin la muerte al sentido, o vence la naturaleza, eliminando la salud al dolor. En cambio, en el otro mundo el dolor persiste causando sufrimiento, y la naturaleza continúa percibiéndolo. Ambos persistirán para que no desista el castigo.

$$
[\ldots]
$$

${ }^{210}$ Apocalipsis 2,11; 20,6; 21,8. 


\section{LIBRO XXII}

\section{CAPÍTULO XXIII}

Males Particulares Que, ADEMÁS DE LOS COMUNES A BUENOS Y MALOS, SIRVEN PARA EJERCITAR A LOS JUSTOS

A más de los males de esta vida, comunes a buenos y a malos, tienen en ella los justos sus propios trabajos: luchan contra los vicios, y se encuentran expuestos a las tentaciones y peligros de tales combates. Unas veces con más reciedumbre, otras con más calma, no deja la carne de ser opuesta en sus deseos al espíritu y el espíritu en los suyos a la carne, no haciendo lo que queremos ${ }^{211}$, aplastando totalmente la mala concupiscencia, sino que, ayudados por la divina gracia, procuremos someterla no consintiendo en sus atractivos. Vigilemos de continuo para que no nos engañe una falsa apariencia de verdad, ni nos embauque el discurso elegante, ni se desplieguen ante nosotros las tinieblas del error, ni se tome lo bueno por malo ni lo malo por bueno, ni el miedo nos aparte de nuestras obligaciones, ni se ponga el sol durante nuestro enojo ${ }^{212}$, ni la enemistad nos provoque a devolver mal por mal ${ }^{213}$, ni nos consuma una tristeza indigna y sin medida, ni la mente ingrata se muestre tarda en corresponder a los beneficios, ni la buena conciencia se deje abatir por maldicientes rumores, ni nos fascine la sospecha temeraria, ni quebrante nuestro espíritu la ajena sospecha falsa, ni reine el pecado en nuestro cuerpo mortal para someternos a sus deseos, ni se sujeten nuestros miembros como arma de iniquidad al pecado ${ }^{214}$, ni vaya nuestro ojo tras los malos deseos, ni se sobreponga el ansia de la venganza, ni se entretenga la vista o el pensamiento en el deleite que arrastra al mal, ni se escuche de buen grado la palabra desvergonzada o indecente, ni se haga lo que no es lícito, aunque agrade; finalmente, que en esta contienda rebosante de trabajos y peligros no esperemos conseguir la victoria por nuestras propias fuerzas, ni la atribuyamos a ellas si la hemos conseguido, sino a la gracia de aquel de quien nos dice el Apóstol: Demos gracias a Dios, que nos da esta victoria por medio de nuestro Señor Jesucristo ${ }^{215}$. Así como dice también en otro lugar: Todo esto lo superamos de sobra gracias al que nos amón ${ }^{16}$.

\footnotetext{
${ }^{211}$ Gálatas 5,17.

212 Efesios 4,26.

213 Romanos 12,17.

214 Romanos 6,12-13.

2151 Corintios 15,57.

${ }^{216}$ Romanos 8,37.
} 
Tengamos presente con todo, por mucho valor que despleguemos en la lucha contra los vicios, y aunque los hayamos superado ya y sometido, tengamos presente que mientras estamos en este cuerpo no nos faltará nunca motivo para decir a Dios: Perdónanos nuestras deudas ${ }^{217}$. En cambio, en el reino donde estaremos para siempre con cuerpos inmortales ni habrá lucha alguna ni deudas; ni las habría habido nunca en parte alguna si nuestra naturaleza hubiera permanecido recta como fue creada. Y por ello también esta situación conflictiva en que nos debatimos y de la que deseamos vernos libres con la última victoria, es propia de los males de esta vida, que con el testimonio de tantas y tan graves miserias comprobamos se halla entregada a la condenación.

\section{CAPÍTULO XXIV \\ Bienes DE QUe el Creador ha COlmado ESTA VIDA, AUNQUE SUJETA A LA CONDENACIÓN}

1. Es tiempo ya de considerar la calidad y cantidad de bienes con que la bondad del mismo que administra cuanto ha creado colmó esa misma miseria del género humano, en que campea la alabanza de la justicia que castiga. En primer lugar, ni aun después del pecado tuvo a bien retirar la bendición que había dado antes del pecado diciendo: Creced, multiplicaos, llenad la tierra ${ }^{218}$, y permaneció en el linaje humano la fecundidad otorgada; así como tampoco el vicio del pecado, por el que se nos infligió la muerte inevitable, pudo suprimir la admirable virtud de las semillas, ni la más admirable aún, productora de esas mismas semillas, virtud depositada y como inoculada en los cuerpos humanos. Por el contrario, corren juntos en este río, en ese torrente del género humano los dos elementos: el mal que se arrastra desde el primer padre y el bien que otorga el Creador. En el mal original hay dos cosas: el pecado y la pena; en el bien original, otras dos: la propagación y la conformación ${ }^{219}$.

Por lo que se refiere a nuestro plan presente, ya hemos hablado bastante sobre esos dos males: el uno, procedente de nuestra audacia, esto es, el pecado; el otro, el castigo, del juicio de Dios. Ahora me propongo tratar de los bienes de Dios, que comunicó a la misma naturaleza, viciada

\footnotetext{
217 Mateo 6,12.

218 Génesis 1,28.

219 Con estos dos términos Agustín explica el mandato divino de la reproducción. La propagación significa la diseminación de la raza humana en la Tierra; la conformación, al deber de replicar ontológicamente al ser humano para continuar el trazado divino iniciado en la Creación.
} 
como estaba y condenada, y continúa concediendo hasta ahora. En realidad, al lanzar sobre ella esa condenación, ni le arrebató todo lo que le había dado (de otra manera ni existiría siquiera), ni la emancipó de su potestad, incluso cuando la sujetó al diablo, para su castigo, ya que ni al mismo diablo ha excluido de su imperio. La subsistencia misma de la naturaleza diabólica es obra de su mano soberana, como lo es cualquier cosa que de algún modo existe.

2. Pasemos a aquellos dos bienes que dijimos manaban como de la fuente de su bondad en la naturaleza viciada por el pecado y condenada al castigo. El primero, la propagación, lo otorgó junto con su bendición a las obras del mundo, de las cuales descansó el día séptimo; la conformación o perfeccionamiento la está llevando a cabo hasta el presente. Si efectivamente sustrajera su potencia eficaz, ni podrían continuar su curso y cumplir el tiempo con la regularidad de sus movimientos, ni permanecerían en el mínimo que tienen de criaturas. Dios, pues, creó al hombre en tales condiciones que le añadió la fecundidad generadora de otros hombres, asociándoles la misma posibilidad de la propagación, aunque no la necesidad; bien que se la quitó a quienes le plugo y se quedaron estériles. Sin embargo, no le quitó el género humano esa bendición de engendrar otorgada a la primera pareja. Pero esta propagación, aunque no fue suprimida por el pecado, no es, sin embargo, como hubiera sido si nadie hubiera pecado. Desde que el hombre, colocado en tal honor, por su pecado fue comparado con los animales ${ }^{220}$, engendra de modo semejante a ellos, aunque no se ha apagado en él el destello de la razón, que le hace ser a imagen de Dios.

Claro que si no concurriera la conformación a esta propagación no tendría lugar según sus propias formas y modos, ya que si no se hubiera dado la unión entre el hombre y la mujer, y, con todo, quisiera Dios llenar la tierra de hombres, lo mismo que creó uno sin esa unión, hubiera podido crearlos a todos; y, en cambio, aunque ellos tuvieran esas relaciones, no podrían engendrar sin su obra creadora. Como dice el Apóstol sobre la formación espiritual, por la cual se forma el hombre en orden a la piedad y la justicia: ni el que planta significa nada, ni el que riega tampoco, cuenta el que hace crecer, o sea, Dios ${ }^{221}$, otro tanto tendríamos que decir a este propósito: "Ni quien se acuesta con alguien, ni el que siembra, es algo, sino Dios que da la forma. Ni la madre que lleva lo concebido y lo alimenta ya dado a luz es algo, sino Dios que da el desarrollo”. Efectivamente, Él mismo

220 Salmos 49,13; 21.

2211 Corintios 3,7. 
con su operación, que continúa hasta el presente, es el que hace que las semillas cumplan sus tiempos y, despojadas de ciertas envolturas latentes e invisibles, adopten la hermosura de estas formas que contemplamos.

Él también, uniendo y asociando por modos maravillosos las naturalezas incorpórea y corpórea, aquélla para dar órdenes y ésta para obedecer, produce el ser animado. Obra esta tan grande y admirable que no sólo en el hombre, animal racional, y por ello más excelente y aventajado que todos los seres animados terrenos, sino hasta en el más insignificante ratoncillo deja atónita la mente de quien con atención lo medita y le hace prorrumpir en alabanzas del Creador.

3. Es Él quien ha dado la mente al alma humana, aunque en el infante la razón y la inteligencia se encuentren como adormecidas, como si no existieran, y han de ser excitadas y ejercitadas con el desarrollo de la edad para llegar a hacerse capaces de la ciencia y de la doctrina, y hábiles para percibir la verdad y el amor del bien. Con esa capacidad ya puede el hombre gustar la sabiduría y adornarse con las virtudes. Con ellas, con la prudencia, la fortaleza, la justicia y la templanza luchará contra los errores y restantes vicios innatos, y los superará, no llevado del deseo de cosa alguna, sino del sumo e inmutable bien. Y aunque no llegue a conseguirlo, ¿quién puede explicar cabalmente, ni siquiera pensarlo, qué bien tan grande, qué obra admirable del Omnipotente en esa misma capacidad de tales bienes otorgada por obra divina a la naturaleza racional?

Además del arte del bien vivir y de llegar a la felicidad inmortal, arte que llamamos virtud, y que se da solamente por la gracia de Dios, que está en Cristo, a los hijos de la promesa y del reino, ¿no es obra del ingenio humano el descubrimiento y ejercicio de tantas y tan excelentes artes, en parte necesarias y en parte por placer? ¿Y no da testimonio esa excelente pujanza de la mente y de la razón, aun en estas cosas superfluas y hasta peligrosas y supersticiosas que apetece, no da testimonio del inmenso tesoro que encierra su naturaleza, de que pudo descubrir, aprender o practicar tales artes? Ahí tenemos las obras maravillosas y estupendas a que ha llegado la industria humana en la confección de vestidos y en la construcción; las metas alcanzadas en la agricultura y en la navegación; la perfección que ha imaginado y logrado en la fabricación de ciertos vasos y en la variedad de estatuas y pinturas; las realizaciones que ha llevado a las tablas, tan admirables para los espectadores como increíbles de ser conseguidas y exhibidas para los oyentes; los formidables recursos descubiertos en la caza, muerte y doma de las bestias salvajes; cuántas clases de venenos, de armas y máquinas contra los mismos hombres, y cuántos medicamentos 
y recursos ha inventado también para la defensa y reparación de la vida corporal; cuántos condimentos y excitantes del placer y la gula; qué multitud y variedad de signos para manifestar e inculcar las ideas, en las que juega un papel tan principal la palabra y la escritura; qué recursos del lenguaje, qué abundancia de ritmos diversos para deleitar los espíritus; qué cantidad de instrumentos musicales, qué variedad en el canto para recreo del oído; con qué sagacidad ha adquirido una inmensa pericia de las dimensiones y de los números, del giro y orden de las estrellas. ¿Quién podría, finalmente, expresar el vasto conocimiento con que se ha enriquecido sobre las cosas mundanas, en especial si queremos recorrer cada sector en particular, no considerando todo en montón? Y ya, para terminar ¿quién será capaz de apreciar con qué grandeza brilló el ingenio de herejes y filósofos en la defensa de sus errores y falsedades?

Hablamos sólo de la naturaleza de la mente humana, que caracteriza a esta vida mortal, no de la fe y del camino de la verdad, con que se consigue la vida inmortal. Siendo el Dios verdadero y supremo el creador de naturaleza tan excelente, gobernando Él cuanto hizo y teniendo el supremo poder y la suprema justicia, no hubiera caído aquélla en las miserias actuales ni después de ellas caminaría a las eternas — con excepción de sólo los que se han de librar-, si no hubiera precedido un pecado enorme en el primer hombre, del que nacieron los demás.

4. Hemos también de parar la atención en el mismo cuerpo: aunque lo tengamos común con las bestias y sea más débil que muchas de ellas, ¿qué bondad de Dios, qué providencia de tan alto Creador no brilla en él? ¿o están en él ordenados los sentidos y dispuestos los restantes miembros, no está toda su configuración y su estatura adaptada, manifestando que fueron hechos para el servicio del alma racional?

No fue, de hecho, creado el hombre como los animales irracionales que vemos inclinados hacia la tierra; la forma del cuerpo levantada hacia el cielo le exhorta a centrarse en las cosas de arriba. Y esa maravillosa agilidad de su lengua y de sus manos, tan idónea y apropiada para hablar y para escribir, lo mismo que para realizar obras de las más variadas artes y oficios, ¿no muestra con suficiente claridad la excelente cualidad de un alma a quien se ha dado un cuerpo tal para su servicio?

Aunque, dejando a un lado las necesidades de esas obras, la conveniencia de todas las partes es tan armoniosa y se corresponde con simetría tan hermosa que no se podría afirmar si en la creación del cuerpo se tuvo más en cuenta la utilidad que la belleza. Realmente, no vemos en el hombre 
nada creado que tenga un fin utilitario y a la vez no sea una expresión de belleza. Esto nos aparecería más claro si conociéramos las proporciones que unen entre sí todas estas partes. Quizá pudiera llegar a investigarlas la habilidad humana con una atención especial en los detalles que aparecen al exterior. En cambio, no es fácil que nadie llegue a descubrir las partes que están ocultas y alejadas de nuestras miradas, como las sinuosidades de las venas, nervios y vísceras, lugares secretos de las partes esenciales de la vida. Aunque la diligencia cruel de los médicos que llaman anatómicos ha desgarrado los cuerpos de los muertos y hasta de los que mueren entre sus manos mientras cortan y examinan, y aunque ha escudriñado asaz inhumanamente hasta lo más recóndito en las carnes humanas para llegar a conocer qué es lo que había que curar, cómo habían de hacerlo y en qué lugares había que aplicar el remedio; sin embargo, ¿hemos de decir que no pudo nadie encontrar — porque no osó buscar- esas proporciones de que consta la disposición que los griegos llaman armonía, extrínseca e intrínseca de todo el cuerpo a la manera de un instrumento de música? Si se hubieran podido conocer esas medidas o proporciones, incluso en las vísceras interiores (que no muestran ningún atractivo), sería tal la belleza que encandilaba a la razón, que la tendría por muy superior a la belleza aparente que le entra por los ojos.

Hay, por otra parte, algunos elementos en el cuerpo que sólo muestran cierta belleza, no utilidad alguna; como ocurre con las mamilas en el pecho del varón, con la barba de su rostro, que no es ciertamente una defensa, sino un adorno del varón, como lo indica el rostro lampiño de la mujer, que, como más débil, sería preciso proteger con más seguridad. Por consiguiente, si no hay miembro alguno, al menos en los más destacados (de lo cual no duda nadie), que esté acomodado a su función sin que a la vez tenga belleza, $y$, por otra parte, existen algunos en que se encuentra sólo belleza sin utilidad, claramente se deduce, según mi opinión, que en la creación del cuerpo se antepuso la dignidad a la necesidad. Esta sabemos es pasajera, y ha de venir un tiempo en que nos gozaremos mutuamente de sola la belleza sin mezcla de pasión. Lo cual ha de ceder, sobre todo, en alabanza del Creador, a quien se dice en el salmo: Te vistes de belleza y majestad $^{222}$.

5. Ahora bien, ¿¿qué composición literaria podría reflejar dignamente la belleza y utilidad de las demás criaturas que otorgó la prodigalidad divina para recreo y provecho del hombre, aunque arrojado y condenado a estos trabajos y miserias? Harto brilla y resplandece en la fúlgida y variada hermo-

${ }^{222}$ Salmos 104,1. 
sura del cielo, la tierra y el mar; en las frondosidades de los bosques, los colores y aromas de las flores; en la multitud y diversidad de parleras y pintadas aves; en la multiforme hermosura de tantos y tan grandes animales, de los cuales suscitan mayor admiración los que son más pequeños (más nos sorprendemos ante las obras de las hormigas y las abejas que ante los desmesurados cuerpos de las ballenas); en el espectáculo grandioso del mismo mar, cuando se nos presenta engalanado de diversos colores como otros tantos vestidos, y ya aparece verde con mil matices, ya purpúreo, ya azulado. ¿Con qué placer no se contempla también cuando se embravece, y se origina mayor deleite por recrear al que lo contempla sin azotar ni sacudir al navegante? Y ¿qué diremos de la abundancia de alimentos esparcidos por todas partes contra el hambre? ¿Qué de la diversidad de exquisitos sabores contra el hastío, derramados en las riquezas de la naturaleza, no inventados por el trabajo y la habilidad de los cocineros? ¿Qué recursos para defender y recuperar la salud no se encuentran en tantas cosas? ¡Qué grata sucesión en la alternación del día y de la noche, qué acariciadora la temperatura del ambiente! ¡Y cuánta materia para confeccionar los vestidos tanto en los frutos como en los animales! ¿Quién sería capaz de enumerar todo esto?

Sólo estos ejemplos, que he querido citar como en resumen, si quisiera soltarlos como envoltorios bien cerrados y desarrollarlos, ¿cuánto tendría que detenerme en cada uno de ellos, que tantísimos misterios encierra en sí? Y hay que tener presente que todo esto no es sino consuelo de los miserables y condenados, no recompensa de los bienaventurados. ¿Cuáles serán, pues, aquellas recompensas si estos consuelos son tantos, tan grandes y de tal calidad? ¿Qué no dará a los que predestinó a la vida quien ha dado todo esto, incluso a los que predestinó a la muerte? ¿De qué bienes no hará partícipes en la vida bienaventurada a aquellos por quienes ha querido que su Hijo unigénito soportara hasta morir males tan grandes en esta vida calamitosa? Por eso, el Apóstol, hablando de esos predestinados al reino, dice: Quien no escatimó a su propio Hijo, sino que lo entregó por todos nosotros, ¿cómo es posible que con Él no nos lo regale todo?223

Ahora bien, cuando se cumpla esta promesa, ¿qué seremos, cómo nos encontraremos, qué bienes recibiremos en aquel reino si con la muerte de Cristo por nosotros hemos recibido ya tal prenda? ¿Cómo estará entonces el espíritu del hombre sin vicio alguno a que estar sujeto ni al cual ceder, ni contra el cual, aún loablemente, combatir, inmerso en la paz de una virtud acabada? Y ¿cuán inmenso, cuán hermoso y seguro no será allí el conocimiento de todas las cosas, sin lugar a error y sin esfuerzo para adqui-

223 Romanos 8,32. 
rirlo, abrevándose en la mismísima fuente de la sabiduría de Dios, con felicidad suprema, sin dificultad alguna? ¿Cómo estará entonces el cuerpo, sometido en todo al espíritu, totalmente vivificado por él, sin necesidad de alimento alguno? Porque ya no será entonces animal, sino espiritual, conservando ciertamente la sustancia de la carne, pero sin resto de corrupción carnal.

\section{CAPÍTULO XXX}

\section{LA FELICIDAD ETERNA DE LA CIUDAD DE DiOS, Y EL SÁBADO PERPETUO}

1. ¡Qué intensa será aquella felicidad, donde no habrá mal alguno, donde no faltará ningún bien, donde toda ocupación será alabar a Dios, que será el todo para todos! ${ }^{224}$ No sé qué otra cosa se puede hacer allí, donde ni por pereza cesará la actividad, ni se trabajará por necesidad. Esto nos recuerda también el salmo donde se lee o se oye: Dichosos los que viven en tu casa alabándote siempre ${ }^{225}$.

Todos los miembros y partes internas del cuerpo incorruptible, que ahora vemos desempeñando tantas funciones, como entonces no habrá necesidad alguna, sino una felicidad plena, cierta, segura, sempiterna, se ocuparán entonces en la alabanza de Dios. En efecto, todo aquel ritmo latente de que hablé en la armonía corporal repartido exterior e interiormente por todas las partes del cuerpo, no estará ya oculto, y junto con las demás cosas grandes y admirables que allí se verán, encenderán las mentes racionales con el deleite de la hermosura racional en la alabanza de tan excelente artífice. Cuáles han de ser los movimientos de tales cuerpos que allí tendrán lugar, no me atrevo a definirlo a la ligera, porque no soy capaz de concebirlo. Sin embargo, tanto el movimiento como la actitud al igual que su porte exterior, cualquiera que sea, será digno allí donde no puede haber nada que no lo sea. Cierto también que el cuerpo estará inmediatamente donde quiera el espíritu; y que el espíritu no querrá nada que pueda desdecir de sí mismo o del cuerpo.

Habrá verdadera gloria allí donde nadie será alabado por error o adulación de quien alaba. No se dará el honor a ningún indigno donde no se admitirá sino al digno. Habrá paz verdadera allí donde nadie sufrirá contrariedad alguna ni por su parte ni por parte de otro. Será premio de la virtud el mismo que dio la virtud y de la que se prometió como premio Él mismo, que es lo mejor y lo más grande que puede existir.

${ }^{224} 1$ Corintios 15,28 .

${ }^{225}$ Salmos 84,5. 
¿Qué otra cosa dijo por el profeta en aquellas palabras: Seré vuestro Dios y vosotros seréis mi pueblo ${ }^{226}$, sino: Yo seré su saciedad, yo seré lo que puedan desear honestamente los hombres, la vida, la salud, el alimento, la abundancia, la gloria, el honor, la paz, todos los bienes? Así, en efecto, se entiende rectamente lo que dice el Apóstol: Dios lo será todo para to$d_{o s} 227$. Será meta en nuestros deseos Él mismo, a quien veremos sin fin, amaremos sin hastío, alabaremos sin cansancio. Este don, este afecto, esta ocupación será común a todos, como lo es la vida eterna.

2. Por lo demás, ¿quién es capaz de pensar, cuanto más de expresar, cuáles serán los grados del honor y la gloria en consonancia con los méritos? Lo que no se puede dudar es que existirán. Y también aquella bienaventurada ciudad verá en sí el inmenso bien de que ningún inferior envidiará a otro que esté más alto, como no envidian a los arcángeles el resto de los ángeles. Y tanto menos querrá cada uno ser lo que no ha recibido cuanto no quiere en el cuerpo el dedo ser ojo, por más estrecha trabazón corporal que une a ambos miembros. Uno tendrá un bien inferior a otro, y se contentará con su bien sin ambicionar otro mayor.

3. Ni dejarán tampoco los bienaventurados de tener libre albedrío, por el hecho de no sentir el atractivo del pecado. Al contrario, será más libre este albedrío cuanto más liberado se vea, desde el placer del pecado hasta alcanzar el deleite indeclinable de no pecar. Pues el primer libre albedrío que se dio al hombre, cuando fue creado en rectitud al principio, pudo no pecar, pero también pudo pecar; este último, en cambio, será tanto más vigoroso cuanto que no podrá caer en pecado. Claro que esto también tiene lugar por un don de Dios, no según las posibilidades de la naturaleza. Una cosa es ser Dios y otra muy distinta ser partícipe de Dios. Dios, por su naturaleza, no puede pecar; el que participa de Dios recibe de Él el no poder pecar. Había que conservar una cierta gradación en los dones de Dios; primero se otorgó el libre albedrío, mediante el cual pudiera el hombre no pecar, y después se le dio el último, con el que no tuviera esta posibilidad: aquél para conseguir el mérito; éste para disfrutar de la recompensa.

Pero como esta naturaleza pecó cuando pudo pecar, necesitó ser liberada con una gracia más amplia, para llegar a aquella libertad en la cual no pueda pecar. Así como la primera inmortalidad, que perdió Adán por el pecado, consistía en poder no morir, la última consistirá en no poder morir; así el primer libre albedrío consistió en poder no pecar, y el segundo en no poder pecar. En efecto, tan difícil de perder será el deseo de practicar la

\footnotetext{
${ }^{226}$ Levítico 26,12.

2271 Corintios $15,28$.
} 
piedad y la justicia, como lo es el de la felicidad. Pues, ciertamente, al pecar no mantuvimos ni la piedad ni la felicidad, pero no perdimos la aspiración a la felicidad ni siquiera con la pérdida de la misma felicidad. ¿Se puede acaso negar que Dios, por no poder pecar, carece de libre albedrío? Una será, pues, en todos e inseparable en cada uno la voluntad libre de aquella ciudad, liberada de todo mal, rebosante de todos los bienes, disfrutando indeficientemente de la alegría de los gozos eternos, olvidada de sus culpas y olvidada de las penas; sin olvidarse, no obstante, de su liberación de tal suerte que no se muestre agradecida al liberador.

4. Se acordará, ciertamente, de sus males pasados en cuanto se refiere al conocimiento racional, pero se olvidará totalmente de su sensación real. Como le ocurre al médico muy experto, que conoce por su arte casi todas las enfermedades del cuerpo, y, sin embargo, experimentalmente ignora la mayoría, las que no ha padecido en su cuerpo. Hay, pues, dos conocimientos de males: uno, por el poder de la mente que los descubre; y otro, por la experiencia de los sentidos que los soportan (de una manera se conocen todos los vicios por la ciencia del sabio, y de otra, por la vida pésima del necio). Así hay también dos maneras de olvidarse de los males: de una manera los olvida el instruido y el sabio, y de otra, el que los ha experimentado y sufrido: el primero, descuidando su ciencia; el segundo, al verse libre de la miseria. Esta última manera de olvidar que he citado es la que tienen los santos no acordándose de sus males pasados: carecerán de todos, de tal manera que se borran totalmente de sus sentidos. En cambio, en cuanto al poder de su conocimiento, que será grande en ellos, no se le ocultará ni su miseria pasada, ni siquiera la miseria eterna de los condenados. Si así no fuera, si llegaran a ignorar que habían sido miserables, ¿cómo, al decir del salmo, cantarán eternamente las misericordias del Señor? ${ }^{228}$ Por cierto, aquella ciudad no tendrá otro cántico más agradable que éste para glorificación del don gracioso de Cristo, por cuya sangre hemos sido liberados.

Allí se cumplirá aquel descansad y ved que yo soy el Señor ${ }^{229}$. Ese será realmente el sábado supremo que no tiene ocaso, el que recomendó Dios en las primeras obras del mundo al decir: $Y$ descansó Dios el día séptimo de toda su tarea. Y bendijo Dios el día séptimo y lo consagró, porque ese día descansó Dios de toda su tarea de crear ${ }^{230}$.

También nosotros seremos ese día séptimo; seremos nosotros mismos cuando hayamos llegado a la plenitud y hayamos sido restaurados por su bendición y su santificación. Allí con tranquilidad veremos que Él mismo

\footnotetext{
228 Salmos 89,2.

229 Salmos 46,11.

230 Génesis 2,2-3.
} 
es Dios: lo que nosotros quisimos llegar a ser cuando nos apartamos de Él dando oídos a la boca del seductor: Seréis como dioses ${ }^{231}$, y apartándonos del verdadero Dios, que nos haría ser dioses participando de Él, no abandonándole. Pues ¿qué es lo que conseguimos sin Él, sino caer en su cólera?232 En cambio, restaurados por Él y llevados a la perfección con una gracia más grande, descansaremos para siempre, viendo que Él es Dios, de quien nos llenaremos cuando Él lo sea todo para todos ${ }^{233}$.

Incluso nuestras mismas buenas obras, cuando son reconocidas más como suyas que como nuestras, entonces se nos imputan a nosotros para el disfrute de este sábado. Porque si nos las atribuimos a nosotros, serán serviles; y está escrito del sábado: No haréis en él obra alguna servil ${ }^{234}$. Por eso se dice por el profeta Ezequiel: Les di también mis sábados como señal recíproca, para que supieran que yo soy el Señor que los santifico ${ }^{235}$. Esto lo conoceremos perfectamente cuando consigamos el perfecto reposo y veamos cabalmente que Él mismo es Dios.

5. Por otra parte, si el número de edades, como el de días, se computa según los períodos de tiempo que parecen expresados en las Escrituras, aparece ese reposo sabático con más claridad, puesto que resulta el séptimo. La primera edad, como el día primero, sería desde Adán hasta el diluvio; la segunda, desde el diluvio hasta Abrahán, no de la misma duración, sino contando por el número de generaciones, pues que encontramos diez. Desde aquí ya, según los cuenta el Evangelio de Mateo, siguen tres edades hasta la venida de Cristo, cada una de las cuales se desarrolla a través de catorce generaciones: la primera de esas edades se extiende desde Abrahán hasta David; la segunda, desde David a la transmigración de Babilonia; la tercera, desde entonces hasta el nacimiento de Cristo según la carne. Dan un total de cinco edades. La sexta se desarrolla al presente, sin poder determinar el número de generaciones, porque, como está escrito: No os toca a vosotros conocer los tiempos que el Padre ha reservado a su autoridad ${ }^{236}$. Después de ésta, el Señor descansará como en el día séptimo, cuando haga descansar en sí mismo, como Dios, a1 mismo día séptimo, que seremos nosotros.

Sería muy largo tratar de explicar ahora con detalle cada una de estas edades. A esta séptima, sin embargo, podemos considerarla nuestro sába-

\footnotetext{
231 Génesis 3,5.

232 Salmos 90,7-9.

2331 Corintios 15,28.

234 Deuteronomio 5,14.

235 Ezequiel 20,12.

236 Hechos 1,7.
} 
do, cuyo término no será la tarde, sino el día del Señor, como día octavo eterno, que ha sido consagrado por la resurrección de Cristo, significando el eterno descanso no sólo del espíritu, sino también del cuerpo. Allí descansaremos y contemplaremos, contemplaremos y amaremos, amaremos y alabaremos. He aquí lo que habrá al fin, mas sin fin. Pues ¿qué otro puede ser nuestro fin sino llegar al reino que no tiene fin?

Creo haber dado cumplimiento con el auxilio del Señor de esta gran obra. Quienes la tengan por incompleta o por excesiva, perdónenme. En cambio, quienes la vean suficiente, congratúlense conmigo y ayúdenme a dar gracias no a mí, sino a Dios. Amén.

\section{REFERENCIAS BIBLIOGRÁFICAS}

Agustín de Hipona: Confesiones. Madrid: Aguilar, 1947.

Agustín de Hipona: Escritos Filosóficos (2. ${ }^{\circ}$ ). Madrid: Biblioteca de Autores Cristianos, 1951.

Agustín de Hipona: Cartas (1. ${ }^{\circ}$. Madrid: Biblioteca de Autores Cristianos, 1967.

Agustín de Hipona: Escritos Antipelagianos, 5v. Madrid: Biblioteca de Autores Cristianos, 1971.

Agustín de Hipona: Escritos Antimaniqueos, 2v. Madrid: Biblioteca de Autores Cristianos, 1986.

Agustín de Hipona: La Ciudad de Dios, 2v. Madrid: Biblioteca de Autores Cristianos, 1988a.

Agustín de Hipona: Escritos Antidonatistas, 3v. Madrid: Biblioteca de Autores Cristianos, 1988b.

Agustín de Hipona: Escritos Antiarrianos, 3v. Madrid: Biblioteca de Autores Cristianos, 1990.

Augustine: The Political Writings. Henry Paolucci, ed. Regnery Gateway Inc., 1962.

Augustine: City of God. Penguin Books, 1981.

Augustine: The City of God against the Pagans. Cambridge University Press, 1998.

Augustine: Political Writings. E. M. Atkins y R. J. Dodaro, eds. Cambridge University Press, 2001.

Brooke, Christopher: "Rousseau's Political Philosophy: Stoic and Augustinian Origins". En Patrick Riley (ed.), The Cambridge Companion to Rousseau. Cambridge University Press, 2001. Pp. 94-123.

Brown, Peter: Augustine of Hippo. University of California Press, 1967; 2000.

Brown, Peter: The World of Late Antiquity. W. W. Norton \& Co., 1989.

Brown, Peter: Power and Persuasion in Late Antiquity. Towards a Christian Empire. The University of Wisconsin Press, 1992.

Brown, Peter: Authority and the Sacred. Aspects of the Christianization of the Roman World. Cambridge University Press, 1997.

Chadwick, Henry: Augustine. Oxford University Press, 1996.

Chuaqui, Tomás: "La Ética Política de Maquiavelo. Gloria, Poder y los Usos del Mal”. En Estudios Públicos, 79, Invierno, 2000. Pp. 403-435. 
Cicerón: Discursos. Vol. 1. Madrid: Editorial Gredos, 1990.

Cicerón: Sobre la República. Madrid: Editorial Gredos, 1991.

Cicerón: Sobre la Adivinación; Sobre el Destino; Timeo. Madrid: Editorial Gredos, 1999.

Cicerón: Sobre la Naturaleza de los Dioses. Madrid: Editorial Gredos, 2000.

Cicerón: Disputaciones Tusculanas. Madrid: Editorial Gredos, 2005.

Deane, Herbert: The Social and Political Ideas of St. Augustine. Columbia University Press, 1963.

De Courcelles, Dominique: Agustín o el Genio de Europa. Santiago: Dolmen Ediciones, 1998.

Dyson, R. W.: The Pilgrim City. Social and Political Ideas in the Writings of St. Augustine of Hippo. The Boydell Press, 2001.

Elshtain, Jean Bethke: Augustine and the Limits of Politics. University of Notre Dame Press, 1995.

Homero: Odisea. Madrid: Editorial Gredos, 2000.

Long, A. A.: Hellenistic Philosophy. Stoics, Epicureans, Sceptics. Segunda edición, University of California Press, 1986.

Long, A. A., Sedley, D. N.: The Hellenistic Philosophers. Volume 1. Translations of the Principal Sources with Philosophical Commentary. Cambridge University Press, 1992.

Lucano: Farsalia. Madrid: Editorial Gredos, 2001.

Markus, R. A.: Saeculum: History and Society in the Theology of St. Augustine. Cambridge University Press, 1970.

Merdinger, J. E.: Rome and the African Church in the Time of Augustine. Yale University Press, 1997.

Nietzsche, Friedrich: Más Allá del Bien y del Mal. Madrid: Alianza Editorial, 1994.

O’Daly, Gerard: Augustine's City of God: A Reader's Guide. Oxford University Press, 1999.

O’Meara, John: The Young Augustine. The Growth of St. Augustine's Mind Up to his Conversion. Society of St. Paul, $2^{\text {nd }}$ revised edition, 2001.

Ovidio: Fastos. Madrid: Gredos, 2001.

Riley, Patrick: The General Will Before Rousseau: The Transformation of the Divine into the Civic. Princeton University Press, 1986.

Rist, John M.: Augustine. Ancient Thought Baptized. Cambridge University Press, 1997.

Salustio: Conjuración de Catilina; Guerra de Jugurta, etc. Madrid: Editorial Gredos, 2000.

Schuld, J. Joyce: Foucault and Augustine. Reconsidering Power and Love. University of Notre Dame Press, 2003.

Séneca: Epístolas Morales a Lucilio II. Madrid: Editorial Gredos, 2001.

Stump, Eleonore y Norman Kretzmann (eds.), The Cambridge Companion to Augustine. Cambridge University Press, 2001.

Tito Livio: Historia de Roma desde su Fundación. I-III. Madrid: Editorial Gredos, 1990a.

Tito Livio: Historia de Roma desde su Fundación. IV-VII. Madrid: Editorial Gredos, 1990b.

Tito Livio: Historia de Roma desde su Fundación. VIII-X. Madrid: Editorial Gredos, 1990c. 
Tito Livio: Historia de Roma desde su Fundación. XXVI-XXX. Madrid: Editorial Gredos, 2001.

Velásquez, Óscar: "El De Civitate Dei de San Agustín en la perspectiva romana de la gloria”. En Onomazein 2, 1997, pp. 341-353.

Velásquez, Óscar: "Cicerón en el De Civitate Dei de San Agustín: Las complejidades de un diálogo”. En Anuario Filosófico, 2001 (34), pp. 527-538.

Virgilio: Eneida. Madrid: Editorial Gredos, 2000.

Wills, Garry: San Agustín. Barcelona: Mondadori, 2001. 